\title{
Design, empresa, sociedade
}

\author{
Paula da Cruz Landim
}

LANDIM, PC. Design, empresa, sociedade [online]. São Paulo: Editora UNESP; São Paulo: Cultura Acadêmica, 2010. 191 p. ISBN 978-85-7983-093-8. Available from SciELO Books <http://books.scielo.org>.

\section{(1) (1) @(2)}

All the contents of this work, except where otherwise noted, is licensed under a Creative Commons Attribution-Non Commercial-ShareAlike 3.0 Unported.

Todo o conteúdo deste trabalho, exceto quando houver ressalva, é publicado sob a licença Creative Commons Atribuição Uso Não Comercial - Partilha nos Mesmos Termos 3.0 Não adaptada.

Todo el contenido de esta obra, excepto donde se indique lo contrario, está bajo licencia de la licencia Creative Commons Reconocimento-NoComercial-CompartirIgual 3.0 Unported. 


\section{DESIGN, EMPRESA, SOCIEDADE}


CONSELHO EDITORIAL ACADÊMICO

Responsável pela publicação desta obra

\author{
João Candido Fernandes \\ João Roberto Gomes de Faria \\ Luiz Gonzaga Campos Porto \\ Marizilda dos Santos Menezes
}




\section{PAULA DA CRUZ LANDIM}

\section{DESIGN, EMPRESA, SOCIEDADE}


(C) 2010 Editora UNESP

\section{Cultura Acadêmica}

Praça da Sé, 108

01001-900 - São Paulo - SP

Tel.: (0xx11) 3242-7171

Fax: (0xx11) 3242-7172

www.editoraunesp.com.br

feu@editora.unesp.br

CIP - Brasil. Catalogação na fonte

Sindicato Nacional dos Editores de Livros, RJ

L246d

Landim, Paula da Cruz

Design, empresa, sociedade / Paula da Cruz Landim. - São Paulo :

Cultura Acadêmica, 2010.

il.

Inclui bibliografia

ISBN 978-85-7983-093-8

1. Desenho industrial. 2. Desenho industrial - Estudo e ensino. 3. Desenho industrial - Aspectos sociais. I. Título 11-0141.

CDD: 745.44

CDU: 745

Este livro é publicado pelo Programa de Publicações Digitais da Pró-Reitoria de Pós-Graduação da Universidade Estadual Paulista "Júlio de Mesquita Filho" (UNESP)

Editora afiliada:

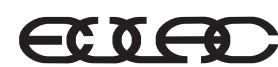

Asociación de Editoriales Universitarias de América Latina y el Caribe

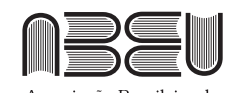

Associação Brasileira de Editoras Universitárias 
Remember yesterday, live today, design tomorrow. 



\section{Agradecimentos}

A realização deste trabalho só foi possível graças ao apoio incondicional de algumas pessoas e instituições.

Ao meu marido, Geraldo, um grande companheiro, por acreditar que eu seria capaz, mesmo quando eu não achava.

Aos meus filhos, meus melhores projetos, Pedro e Júlia, pela compreensão das minhas ausências e por estarem sempre presentes.

Aos meus pais, sempre, e por tudo.

Aos Judice: Marcelo, Andrea e Lucas, meu pedaço de Brasil na Finlândia. E aos que estiveram comigo nesse período, pessoalmente e virtualmente.

Ao professor Pekka Korvenma, que tornou possível meu estágio de pós-doutorado na Universidade de Artes e Design de Helsinque, na Finlândia.

Aos meus colegas do Departamento de Desenho Industrial da FAAC, Unesp - Bauru, pelo apoio e estímulo. Particularmente ao professor Plácido.

À reitoria da Unesp, especialmente à pró-reitoria de Pesquisa, pela bolsa de pós-doutorado.

À Fundunesp, pelo auxílio-pesquisa concedido.

Aos designers, conhecidos ou não, que gentilmente responderam às minhas questões.

A todos, meu muito obrigado. 



\section{SUMÁRIO}

Introdução 11

1 Design e designer 21

2 Design e cultura de massa 35

3 Design finlandês: antecedentes históricos 63

4 Design brasileiro: antecedentes históricos 109

5 Panorama atual brasileiro 121

6 O ensino de design no Brasil 141

7 Discussão 153

8 Conclusão 179

Referências bibliográficas 189 



\section{INTRODUÇÃO}

Com a globalização da economia de livre mercado, também o design tornou-se um fenômeno verdadeiramente global. Por todo o mundo industrializado, fabricantes de todos os tipos reconhecem e implementam cada vez mais o design como um meio essencial para chegar a um novo público internacional e para adquirir vantagem competitiva. Mais do que nunca, os produtos do design dão forma a uma cultura material mundial e influenciam a qualidade do nosso ambiente e o nosso cotidiano.

O design então, segundo Moraes (1999), tende a suplantar suas referências regionais, passando a utilizá-las com discrição e sutileza como forma de identidade cultural decodificada, sem, entretanto, comprometer o produto final frente à competição global. Dessa forma, a inserção da cultura local seria mais um aspecto a ser considerado no desenvolvimento de novos produtos. Assim, os produtos globais tornaram-se um novo desafio para designers e fabricantes, ao mesmo tempo que se transformaram em potencial estratégico de mercado para os países e suas respectivas indústrias.

Por exemplo, a Finlândia, ao longo da história de sua cultura material, destacou-se no design com o uso da madeira curvada em mobiliários, tradicionalmente reconhecidos pela sua inovação, qualidade e bom design, principalmente na pessoa de Alvar Aalto (Figura 1). 

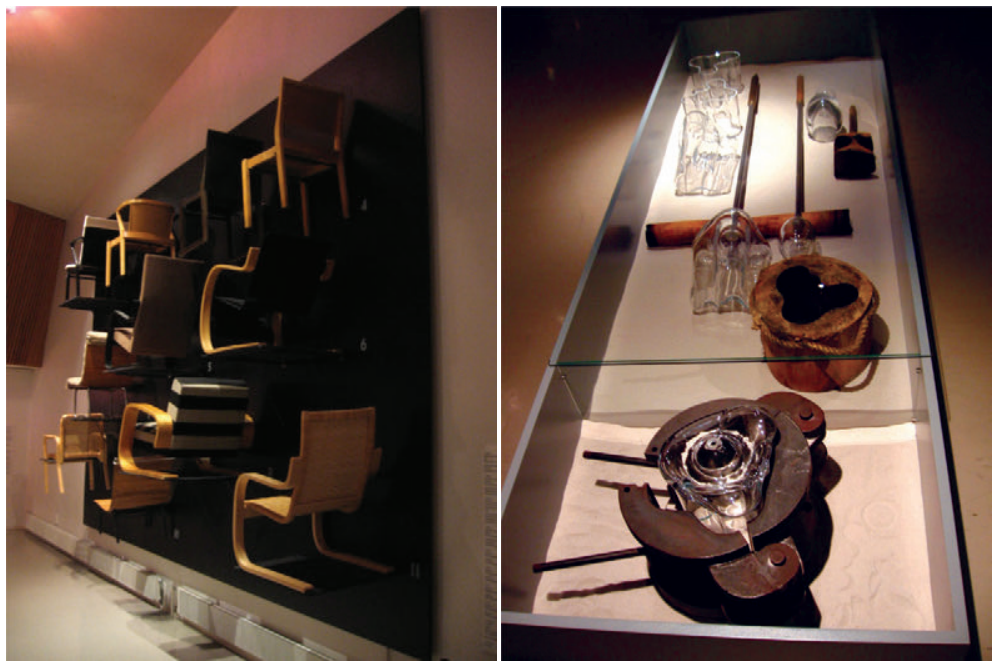

Figura 1 - Mobiliário e peças de vidro de Alvar Aalto. Museu Alvar Aalto, Jyväskylä, Finlândia.

Esses produtos, além de uma imagem de produção semiartesanal cuidadosamente preservada, possuem características que os destacam nitidamente dos produtos de outros países, e são, portanto, considerados sinônimo de design finlandês, funcionando como estratégia promocional de marketing.

Paralelamente, a Finlândia é um dos primeiros países a investir no design social, exemplificado em soluções voltadas para as limitações da terceira idade, a reintegração dos deficientes na sociedade e a busca de melhor qualidade e adequação dos produtos e equipamentos de uso médico-hospitalar. Tais produtos destinam-se ao mercado global e apresentam também uma inovação no tocante ao design finlandês: a utilização de materiais termoplásticos monomateriais na confecção quase integral dos produtos, ilustrando a preocupação dos designers e fabricantes com os aspectos ecológicos, principalmente envolvendo a reciclagem. O design social não é nenhuma novidade enquanto discurso, mas ainda é enquanto prática. Portanto, nas palavras de Moraes, (idem): 
A Finlândia se insere no mercado global de grande escala industrial e de grande consumo (pequenos e médios objetos) mantendose fiel e coerente com sua cultura e tradição, mas ao mesmo tempo voltando-se para os caminhos que aponta o mercado internacional. A expansão de mercado empreendida pelas indústrias finlandesas não implica na substituição dos produtos de vidro e madeira, tradicionalmente reconhecidos; ao contrário, tende a confirmar o estado de maturação dos seus designers, fabricantes e do seu próprio governo.

Em contrapartida, o design no Brasil ainda não está devidamente disseminado. E ainda, quando isso ocorre, é de forma induzida por ações institucionais, levando muitas empresas a adiar seus investimentos nessa área. Por outro lado, as empresas que investem em design acabam por se destacar no mercado em que atuam.

A importância do design não pode, por isso, ser subestimada. Ele abrange uma extraordinária gama de funções, técnicas, atitudes, ideias e valores, todos influenciando nossa experiência e percepção do mundo que nos rodeia, e as escolhas que fazemos hoje sobre a futura direção do design terão um efeito significativo e possivelmente duradouro na qualidade de nossa vida e no ambiente.

A pesquisa em design tem se expandido e ganhado profundidade nos últimos anos. O que este campo de pesquisa pode oferecer de vital nas esferas da indústria, da inovação e da competitividade? Como compartilhar ideias e experiências com especialistas das esferas da indústria, do desenvolvimento de inovações e da universidade? De que forma explorar e demonstrar como a educação em design, a pesquisa e a parceria com indústrias impulsionam as inovações, tanto no âmbito local como no internacional? Como deve ser a pesquisa, em um paradigma em que o design está tornando-se uma intensiva aplicação de conhecimento por um profissional com notória independência disciplinar? O que a pesquisa em design pode oferecer no desenvolvimento de produtos? Como pode ser fortalecido o uso estratégico do design? Quais são os benefícios do design e da pesquisa em design para sistemas de inovação e compe- 
titividade industrial? Como pode a forma de pensamento do design fortalecer a criatividade industrial?

Por outro lado, por que ainda estamos formando designers como talentos criativos isolados no "Planeta Design"? Em que pese a existência de afirmações em contrário, o mercado do design é dirigido pelo gerenciamento da percepção, baseando-se em uma estratégia de visibilidade, trabalhando basicamente o tripé imagem/ percepção/emoção, em que os pontos de tangência e as interfaces com o marketing podem ser observados e, dependendo do campo de atuação do design, difíceis de ser separados.

Desta forma, qual deveria ser o modelo de pesquisa em design? Por que nos apropriamos de modelos de outras áreas de conhecimento?

O "projetar em design” baseia-se nos esquemas clássicos de qualquer criação: definição conceitual, geração de ideias, públicoalvo, tendências, disponibilidade tecnológica, cultura... Em outras palavras, na necessidade de se entender para quem está se projetando, como e por quê.

Não pretendo entrar em uma discussão do termo "design", apesar da minha discordância pessoal, por entender que "design", se traduzido para o português, quer dizer apenas "projeto", havendo, portanto, a necessidade de se complementar "que tipo de projeto?".

Portanto, temos que design pode ser entendido como projeto. Projeto equivale a sonho, que por sua vez é igual a desejo. Projeta-se a casa, uma viagem, o relacionamento ideal... Colocado desta maneira, é claro que o projeto, enquanto ideário, sempre existiu, mas é importante ressaltar a relação desejo/aspiração/possibilidade que se estabelece a partir da mecanização, com a Revolução Industrial. Hoje em dia, tudo tem "design". A questão que se coloca é: qual design? De boa ou má qualidade? Qual o impacto do design na sociedade industrial? Como trabalhar com as necessidades e escolhas culturais, assim como com a tradição frente a novas sensibilidades?

Sendo arquiteta de formação e tendo feito mestrado e doutorado em urbanismo - mas por força das circunstâncias, trabalhando há vinte anos como docente em um curso de design de uma universi- 
dade brasileira -, tenho observado a evolução/transformação tanto do design (particularmente de produto, apenas por ser esta a minha área de atuação) quanto de seu ensino, assim como a crescente formação de massa crítica nacional. E uma questão tem sistematicamente surgido em minhas constantes indagações: até que ponto a formação acadêmica responde aos anseios da sociedade e do setor produtivo?

Desde o início de 2004, eu vinha mantendo contato com o professor Pekka Korvenma, da Universidade de Arte e Design de Helsinque, na Finlândia, e assim surgiu a possibilidade de verificar essas mesmas questões em uma realidade sociocultural e econômica bastante diversa da nossa realidade. Ou seja, eu estava estabelecendo um paralelo com a produção finlandesa ao mesmo tempo em que me aperfeiçoava na área em que atuo. A Universidade de Arte e Design de Helsinque é uma universidade internacional dedicada ao Design, à Comunicação Audiovisual, à Educação de Arte e à Arte. É a maior universidade de seu tipo na Escandinávia e tem presença internacional forte e ativa. Foi fundada em 1871 e é pioneira em pesquisa e educação. É a única instituição oficial a ter graduação em Design. Quando o termo "design” é utilizado na Finlândia, quase sem exceções refere-se a profissionais graduados por essa escola. A universidade também tem sido lembrada como centro de debates sobre a profissão de designer.

A agenda de pesquisa, o material empírico e os métodos aqui apresentados também foram pertinentes ao contexto finlandês. Encontrei profissionais interessados e pesquisadores nos programas de Design de Interiores e de Mobiliário, assim como no de Design Estratégico, sendo que um dos trabalhos de pós-doutorado de pesquisadores locais tem uma temática muito próxima da minha própria pesquisa, fazendo com que ocorresse uma troca frutífera de ideias. Os resultados então são fortemente subsidiados pelo estágio de pós-doutorado cumprido na Universidade de Arte e Design de Helsinque entre agosto de 2006 e maio de 2007.

O objetivo desta pesquisa foi verificar até que ponto a formação acadêmica em cursos de design responde aos anseios da sociedade e 
do setor produtivo. Outro objetivo foi coletar subsídios para a discussão da situação do ensino de design no Brasil e para a elaboração de estratégias que permitam sua melhoria, de maneira a ter profissionais adequados ao desenvolvimento de produtos que, embora com a marca da nossa realidade e cultura, sejam também universais.

Muitas das questões estão ainda em aberto, tornando necessária uma perspectiva interdisciplinar juntamente com um entendimento da relação de causa e efeito. De qualquer forma, as universidades têm um papel-chave em desenvolvimentos futuros. A educação e a pesquisa vão constituir importante capital privado nacional, principalmente em uma sociedade em rede e com a competição globalizada.

Por exemplo, o fator principal que contribuiu para o sucesso internacional nos anos dourados do design finlandês foi o esforço determinado de designers talentosos juntamente com o significativo papel de H. O. Gummerus, diretor de negócios da Sociedade Finlandesa de Artesanato e Design. Mas qual foi o papel da educação? Qual foi a função de suporte do Estado e a demanda da sociedade depois da Segunda Guerra Mundial? Como puderam o Funcionalismo e o Modernismo promover a emergência do design finlandês? Era Marimekko (Figura 2) mais um movimento popular, social e cultural do que um negócio envolvendo marketing e design?



Figura 2 - Exemplos da produção da marca Marimekko. 
Sparshott (1998), filósofo canadense e pesquisador da área de estética, alerta que o futuro é dependente do futuro da Filosofia, que por sua vez baseia-se no desenvolvimento das universidades, e o mesmo pode ser dito em relação ao futuro do design. O tema principal é o papel da pesquisa universitária na criação de "um mapa de conhecimento". Por mapa Sparshott entende a classificação do material pertinente a uma área específica - a estética, pela classificação sistemática das Artes. O futuro da estética é, assim, necessário para o futuro da Filosofia e, por extensão, para o futuro da sociedade, onde as universidades e pesquisas representam um papel importante. Em um ponto de vista similar, poderia ser sugerido que as artes aplicadas, assim como a Arquitetura e o Design, dependem especialmente do desenvolvimento das artes puras e da cultura, assim como das universidades e suas pesquisas.

A estética é tradicionalmente estudada sob o domínio da Filosofia associada com a Arte e o conceito de beleza. O design e o estudo de estética têm feito muito pouco em conjunto. A pesquisa em design tem emprestado largamente suas abordagens da História, da Sociologia e da Semiótica, e mais recentemente da Economia. Tem havido relativamente pouca pesquisa sobre design - este mapa de conhecimento precisa ser construído constantemente.

Para Julier (2006), Design Culture é o estudo das inter-relações entre os artefatos de design em todas suas manifestações possíveis, ou seja, o trabalho dos designers e a produção do objeto - incluindo marketing, publicidade e distribuição - e seu consumo. Portanto, Design Culture refere-se às características formais, como estas são criadas e/ou surgem e os vários significados e funções que o design representa. Estamos vivendo tempos impressionantes. Mídia digital, biotecnologias, sustentabilidade, globalização, mudanças nas estruturas pessoais e políticas, tudo abrindo novos desafios e possibilidades para o design.

Existe, atualmente, um crescimento sem precedentes do uso do design no mundo. Ao mesmo tempo, a prática do design está tornando-se incrivelmente exigente. A profissão requer avanço, 
pensadores criativos que possam entender as circunstâncias complexas e propor respostas inovadoras.

Mas se Design Culture é para ser consolidada como uma disciplina acadêmica, que relação deve ter com outras categorias e com a prática do design? Qual seria o papel da universidade nesse contexto?

Poucas profissões estão tão ligadas ao ensino universitário como o design, e pode-se até afirmar que sua autoimagem passa pela universidade, pois o perfil do profissional dessa área foi dado pela Bauhaus. A escola alemã fundada por Walter Gropius, em 1919, em meio à euforia com o fim da Primeira Guerra Mundial e seus métodos de ensino, forneceu a espinha dorsal para os cursos superiores de design por todo o mundo, marcando de tal modo a imagem do designer que se torna praticamente impossível atualmente entender o que é o design e o designer sem entender o que foi a Bauhaus.

Este trabalho justifica-se pelo momento extremamente frutífero que atravessa o design nacional. Da mesma forma, nos cursos de pós-graduação em Design das universidades brasileiras, o momento também é propício para ações que tenham por objetivo principal o fomento à ciência, à tecnologia e à inovação nessa área, contribuindo para o cenário futuro do design nacional a curto e médio prazo.

As questões relacionadas ao design nacional, sejam elas de cunho analítico ou projetual, são, mais do que nunca, pertinentes e relevantes no atual contexto brasileiro. Durante a última década do século XX e nestes anos iniciais do século XXI, vê-se com satisfação a atividade do designer, assim como sua produção crescer e florescer tanto nos meios acadêmicos como empresariais. O design brasileiro tem se firmado, inclusive internacionalmente, não apenas em termos de premiações em concursos, mas como diferencial competitivo em termos de mercado internacional, devido ao seu incremento paralelamente a uma definição de identidade por meio de uma reflexão histórica sobre o design brasileiro e o modo como a profissão tem se adaptado às mudanças culturais, temporais e tecnológicas.

Paralelamente, os críticos do marketing moderno costumam dizer que quanto mais aumentam as opções de consumo, menos o consumidor parece ter qualquer outra opção senão consumir cada 
vez mais. Existe um fundo de verdade nessa afirmação. Certamente há um ganho, pois há uma variedade maior de opções de consumo, mas existe uma perda também, em termos de conseguir enxergar opções para além do consumo. Não restam dúvidas de que existem mais opções de consumo hoje do que existiam há trinta anos, mas isto não necessariamente se traduz em um aumento proporcional do número de consumidores. $\mathrm{O}$ crescimento do consumo não tem correspondido historicamente a uma ampliação do poder de compra médio. Ao contrário, quanto mais rico fica o país, mais parece aumentar o número de pobres. Para o designer brasileiro, essa simples constatação coloca um grave problema profissional: como fazer design na periferia do sistema? Ou seja, qual seria o papel do design na sociedade brasileira? O que se projeta aqui? O que se deve projetar aqui? Como? Para quem? Será que se pode falar de um design brasileiro propriamente dito? E como ele seria? 



\section{1 \\ Design e Designer}

No mundo moderno, a responsabilidade da relação entre indústria e cultura recai nos ombros do design. O produto é o mediador entre a fabricação e o consumidor, e o seu design é que contém a mensagem.

Para ver o design desta maneira, mais do que simplesmente o mediador entre o status social instantâneo e o estilo - o que a propaganda gostaria que acreditássemos -, deve-se colocá-lo em um contexto muito mais abrangente do que a mídia normalmente apresenta. De acordo com Ono (2006),

considerando-se que o design envolve planejamento, seleção de modos de pensamentos e valores, entende-se que o designer é corresponsável pelas relações que se estabelecem entre os artefatos e as pessoas, bem como pelas suas implicações na sociedade.

Design é um conceito complexo. É ao mesmo tempo processo e resultado do processo. As dimensões, o estilo e o significado dos artefatos foram "designed". ${ }^{1}$ Vários fatores influenciam o processo: a ideias do designer (se houver um envolvido); as determinantes

1 "Desenhados e/ou projetados", em uma tradução livre. 
tecnológicas da fabricação do produto; os contrastes socioeconômicos entre o processo de fabricação e o consumo do produto final; o contexto cultural que dá sentido à necessidade do objeto em primeiro lugar; e as condições de produção. A situação política do país produtor do objeto pode influenciar o modo como este será feito, assim como sua aparência final.

Pode-se ir mais além. O design também é afetado por influências, ideologias sociais e mudanças. As mudanças no papel feminino - tais como no trabalho fabril - e outras atitudes e mudanças sociais têm influenciado a natureza da produção em massa dos artefatos que nos circundam. Forças que encorajem a coesão social são frequentemente sentidas por meio do design dos objetos - algumas vezes são, de fato, estes que sugerem a mudança social.

Desde o século XVIII, a sustentação dominante para o design tem sido o sistema de produção e consumo em massa, baseado na junção de forças da indústria e do comércio. Um dos temas ao qual o design é inevitavelmente ligado é o crescimento da economia capitalista. Está evidente na evolução do design e é parte integrante de seu desenvolvimento, assim como a divisão do trabalho, os objetos de desejo e as empreitadas empresariais para captação de novos mercados. Moda e design, por exemplo, têm estado intrinsecamente ligados desde há muito até os dias atuais.

Em países com necessidade de comunicar uma identidade nacional forte, o design pode também se transformar em uma ferramenta para tal, como é, por exemplo, o caso da Finlândia logo após a Segunda Guerra Mundial. Ou ainda como forma de promover um novo estilo de vida para as donas de casa norte-americanas na década de 1950, por meio dos eletrodomésticos. O design, como significado de comunicação, é capaz de converter tantos significados quantos formos capazes de transmitir.

Entretanto, existe perigo em enfatizar o significado do papel do design no contexto social, econômico, político e ideológico. Apenas nas mãos de produtores responsáveis, designers, críticos e teóricos é que o design pode ser um poderoso agente de transformações. De qualquer maneira, compartilhando a opinião de Ono (idem), 
o design pode constituir-se em prática emancipatória, desde que participe do desenvolvimento de produtos que promovam o aperfeiçoamento, a autoexpressão e a soberania dos indivíduos e das sociedades, inclusive daqueles que vivem em condições de pobreza e à margem dos mercados econômicos.

A democratização do design tornou-se uma realidade que afeta praticamente toda escolha de consumo. A aceleração da redundância estilística tem feito o designer precisar constantemente providenciar novos estilos para substituir os existentes no mercado. Com as vantagens da automação, a indústria organizou seus métodos de produção de forma a atender a esta grande variação estilística. $\mathrm{O}$ antigo sistema fordista, o qual equivalia à produção em massa estandardizada, está morto, assim como a equação do Modernismo de mecanização e universalidade.

É lógico que os valores do Modernismo ainda determinam muito do design, particularmente em educação. Embora isso seja parte da produção e do consumo de massa, alguns designers ainda resistem a esta aliança, preferindo ter seus valores mais relacionados à área de produção artesanal. A história do design moderno desde o século XVIII é a história dessa resistência, da tensão entre as inexoráveis regras do comércio e o idealismo de incontáveis indivíduos que se recusavam a aceitar a morte do artesanato e de seus valores. A principal lição a ser aprendida é que as mudanças culturais são muito mais lentas que as na organização da produção e do consumo. Apesar de, no consumo de massa, as regras da moda e a ligação entre a possessão de certos objetos e o status social serem realidade já no início do século XVIII, até hoje ainda não se aprendeu completamente como chegar em um acordo entre essas forças.

As responsabilidades do designer são várias. Incluem não apenas projetar os componentes do objeto em si, colocando-os juntos de forma apropriada, mas também serem os intérpretes de nossos sonhos, de nossas aspirações e de nossa ansiedade, criando símbolos formais em objetos cotidianos apropriados para tal. Formamos nossas identidades, individuais e/ou coletivas, por meio das coisas que nos cercam, e os designers têm que levar também isto em conta. 
Designers também trabalham com um enorme número de contrastes. Se os objetos são para produção em massa - o que, a partir do século XX, é o caso mais comum -, tem que se trabalhar com todas as demandas da produção industrial, assim como, e cada vez mais importante nas últimas décadas, para qual mercado. Devem-se entender as técnicas de produção e as possibilidades e limitações de cada material. Também se deve ter algum insight sobre as necessidades, desejos e gostos dos consumidores. Os designers são os criadores do ambiente material que habitamos e, desta forma, devem ter uma visão, ou ao menos saber como deveria ser esse ambiente e qual o efeito dele sobre nossas vidas. Alguns têm explorado as possibilidades até o limite, imaginando novas formas e criando novos significados para o objeto projetado. Outros têm trabalhado nos aspectos teóricos e ideológicos do design, posicionando seu papel dentro do grande quadro cultural e econômico. E ainda outros têm tido visões pessoais que têm coincidido com a estética e as necessidades emocionais do público.

Desde os anos 1980, o termo "design" tem sido apropriado pela mass media e pela indústria da propaganda como o "caminho" para agregar "desejabilidade" aos produtos. Consciência de estilo tornou-se condição sine qua non não apenas para os jovens, mas para todo um grupo de consumidores, e mesmo a mais sofisticada diferenciação entre produtos tem sido rotulada como possibilidades estilísticas de escolha determinadas pelo sexo, pela idade ou pela classe. O uso da palavra "design" passou a ser muito explorado pelos meios de comunicação, principalmente na publicidade, demonstrando com isso a força que o design agrega como valor de imagem, mas pouco se fala de seu conteúdo. Possivelmente, o desconhecimento da importância do design no contexto das empresas tenha provocado esse excesso de exposição, gerando equívocos e deturpações como a utilização do design como marca, como Hair Design em vez de cabeleireiro, Flower Design em vez de Floricultura, ou Design Tour para agência de turismo, só para citar alguns exemplos.

O design engloba uma extraordinária variedade de funções, técnicas, atitudes, ideias e valores. É um meio através do qual se 
experimenta e se compreende o mundo que nos rodeia, desde bens de consumo e embalagens até sistemas de transporte e equipamento de produção, e não pode ser totalmente compreendido fora dos contextos social, econômico, político, cultural e tecnológico que levaram à sua concepção e realização.

Definido no sentido mais global como concepção e planejamento de todos os produtos feitos pelo homem, em princípio o design pode ser visto como um instrumento para melhorar nossa qualidade de vida. Ao mesmo tempo, o interesse dos negócios em criar produtos competitivos conduziu à evolução e diversidade do design. Desta forma, ao refletir sobre a história do design industrial, verifica-se que este procura consistentemente desmistificar a tecnologia e oferecê-la em formas acessíveis ao maior número possível de pessoas. Como um canal de comunicação entre pessoas, o design oferece uma visão particular do caráter e do pensamento do designer e de suas convicções do que é importante na relação entre o objeto (solução do design), o utilizador/consumidor, o processo do design e a sociedade.

Os produtos, os estilos, as teorias e as filosofias do design tornaram-se cada vez mais diversificados. Isto devido em grande parte à crescente complexidade do processo do design. Cada vez mais, principalmente para a produção industrial, a relação entre concepção, planejamento e fabricação é fragmentada e complicada por uma série de atividades especializadas interligadas envolvendo diferentes indivíduos, tais como autores dos modelos, pesquisadores de mercado, especialistas de materiais, engenheiros e técnicos de produção. Os produtos do design que resultam desse processo multifacetado não são fruto de designers individuais, mas de equipes de indivíduos, cada um com suas ideias e atitudes sobre como as coisas devem ser feitas. A pluralidade também é devida às alterações de padrões de consumo e de gosto, às alterações de imperativos comerciais e morais de inventores, designers, fabricantes, ao progresso tecnológico e às variações de tendências nacionais do design.

Ao realçar a natureza diversificada do design, objetiva-se demonstrar que as atitudes, as ideias e os valores comunicados pelos 
designers e fabricantes não são absolutos, mas sim condicionais e flutuantes. As soluções do design, mesmo para o mais objetivo dos problemas, são inerentemente efêmeras, como as necessidades e preocupações dos designers, fabricantes de mudanças na sociedade. Talvez a razão mais significativa para a diversidade no design, no entanto, seja a crença generalizada de que, apesar da autoridade e do sucesso de soluções de design particulares, há sempre uma maneira de fazer melhor as coisas. Nas palavras de Ono (idem):

Várias propostas de designers e teóricos emergiram, em reação à multiplicidade de designs, na tentativa de se encontrar uma estética unificada, de abrangência universal e independente da diversidade cultural dos indivíduos, anseios, necessidades e realidades particulares. Proposições deste tipo tornam-se, no entanto, inconsistentes, na medida em que, por mais simples que seja um objeto, a percepção que se tem do mesmo, os significados e usos que assume para cada pessoa variam substancialmente.

Com a globalização da economia de livre mercado, também o design tornou-se um fenômeno verdadeiramente global. Por todo o mundo industrializado, fabricantes de todos os tipos reconhecem e implementam cada vez mais o design como um meio essencial para chegar a um novo público internacional e para adquirir vantagem competitiva. Mais do que nunca, os produtos do design dão forma a uma cultura material mundial e influenciam a qualidade do nosso ambiente e o nosso cotidiano.

O mercado está gerando um número excessivo de produtos semelhantes, com a mesma tecnologia, o mesmo preço, o mesmo desempenho e as mesmas características. Essa avalanche de opções acaba confundindo o consumidor, que tem dificuldade em perceber essas diferenças e em atribuir a elas seu devido valor.

Desse modo, de maneira crescente, muitas indústrias e firmas utilizam o design como forma de se diferenciar das demais.

Atualmente, o design destaca-se como um dos principais fatores para o sucesso de uma empresa, desde o desenvolvimento 
de produtos e serviços até sua comercialização, por meio da otimização de custos, embalagens, material promocional, padrões estéticos, identidade visual, adequação de materiais, fabricação e ergonomia. Além disso, também é um fator essencial de estratégia de planejamento, produção e marketing. O design de embalagens e as estratégias de branding passaram a ser alguns dos grandes diferenciais de um produto ao criarem o impacto visual necessário para sua identificação no ponto de venda. $O$ design de embalagens não apenas atrai o consumidor, ele também estabelece um contato emocional com este.

O design tem também uma enorme importância na gestão. Valorizá-lo é garantir competitividade ao produto e desenvolvimento à empresa, desde que realizado por profissionais experientes, que saibam adequar recursos da empresa, necessidades do mercado e metas a serem alcançadas. Além disso, é pouco provável que o designer, ao seguir toda a metodologia de desenvolvimento de produtos - que, entre outras questões, considera a problematização, o estudo da tarefa, os requisitos e restrições projetuais, os materiais, os processos, a semiótica e o mercado -, desenvolva um produto menos competitivo do que aquele empresário que considere apenas alguns fatores.

Desenvolver um produto sem a participação de um designer pode, muitas vezes, envolver menos custos, mas é um enorme risco. Quando o produto é lançado no mercado é que se evidencia o grande diferencial: os consumidores percebem que o produto não satisfaz e sua reação é não comprar. Com isso, os volumes de venda não atingem patamares satisfatórios, gerando prejuízos.

É importante que o empresariado tenha consciência de que sua decisão de gastar pouco com o desenvolvimento de produtos pode levá-lo a gerar grandes prejuízos mais adiante. O custo de se contratar o trabalho de um bom profissional de design é facilmente recuperado diante dos bons resultados que a empresa experimenta ao longo da vida útil do produto.

Para ser usado de modo estratégico, o design deve participar das definições estratégicas a partir de nível decisório mais alto e 
integrado com todas as áreas relevantes. O design estratégico materializa-se quando o importante é desenvolver o produto certo ter "eficácia do processo de design", e não somente desenvolver corretamente o produto, tendo "eficiência no processo de design". No design estratégico, a forma segue primeiramente a função de comunicar. É importante que os consumidores entendam que aquele produto fornecerá os benefícios desejados, sejam eles oferecidos por funções práticas, estéticas ou por funções simbólicas. Sendo assim, para um design estratégico, a forma segue a mensagem.

A linha de bons produtos de uma empresa garante sua sobrevivência.

Mas o que podemos conceituar como sendo um bom produto?

Sob o ponto de vista comercial, o bom produto é aquele que se vende em quantidades suficientes para cobrir os custos fixos e variáveis e ainda gerar lucro que garanta a manutenção e o desenvolvimento da empresa. Gerenciar a área de desenvolvimento de produtos é uma tarefa desafiadora que envolve inúmeros aspectos: design, mercado, produção, custos, concorrência, novas tecnologias, novos materiais e processos de fabricação, ergonomia, engenharia de produção e muitos outros. Esse é um aspecto que há algum tempo está incorporado às grandes corporações e às marcas de alta visibilidade, que investem em design e obtêm resultados expressivos na conquista da preferência do consumidor.

Seja uma empresa de grande, de médio ou de pequeno porte, no ponto de venda todas têm acesso ao consumidor, e aquela que investe em design tem mais condições de se destacar e se tornar uma marca vencedora. Um design bem feito aumenta a utilidade e o valor de um produto, reduz custos com matéria-prima e produção, além de ampliar a interação com o usuário e realçar a estética.

O design, de fato, desempenha papel econômico expressivo. Entretanto, o público tem enorme dificuldade em compreender a atividade e seus benefícios, tais como o papel social gerador de empregos, educação e qualificação profissional. A maioria dos benefícios percebidos é superficial, ligada à beleza e à comunicação comercial. A percepção dos benefícios dos produtos é agregada às 
marcas proprietárias. O "mercado" tem seus vícios e só consegue avaliar o benefício econômico direto: a cada centavo investido, a quantia de centavos de retorno. Em outras palavras, se essa compreensão da função do design é tão elementar, e os benefícios, tão aparentes, por que ainda hoje é tão difícil justificar o papel do design como atividade transformadora e geradora de benefícios palpáveis?

Por outro lado, assim como existe um prazer do design, existe um design para o prazer. Porém a formação dos designers privilegia as demandas mercadológicas sobre a invenção e inibe a demanda interna pela autoexpressão. Ou seja, a especialização difundida na maioria dos programas de ensino caminha na direção inibidora da inventividade. Entretanto, sendo o design uma atividade social, geradora de bens coletivos, exige uma formação mais ampla, humanista, consciente do impacto ambiental.

Se o objetivo principal do design é o de tornar a vida das pessoas melhor, a prática do design deve responder às necessidades técnicas, funcionais e culturais e criar soluções inovadoras que comuniquem significado e emoção e que transcendam idealmente suas formas, sua estrutura e sua fabricação. Independentemente deste objetivo comum, as respostas à questão "Qual é a sua visão sobre o futuro do design?” são notavelmente variadas.

A crescente disponibilidade de novos materiais sintéticos é largamente identificada como uma das forças de motivação-chave por trás do surgimento de novos produtos. Mas enquanto a maioria dos designers prevê que "a integração de materiais e processos de alta tecnologia alargará e tornar-se-á mais acessível”, outros têm demonstrado a preocupação de que os sintéticos podem, por vezes, ser difíceis de trabalhar e nem sempre são desenvolvidos para resistir ao desgaste do tempo.

As novas tecnologias - computadores, comunicações e processos industriais - têm, nos últimos anos, ajudado muito na pesquisa e implementação do design e prevê-se que originem produtos cada vez mais miniaturizados, multifuncionais e de melhor desempenho. Esses tipos de tecnologias estão contribuindo para melhorar o processo de design, desde o conceito inicial até o protótipo de 
trabalho. Ao acelerar o processo de design, essas tecnologias não só reduzem os custos iniciais dos fabricantes como também proporcionam aos designers grande liberdade de experimentação.

Espera-se que as tecnologias de informação sejam incorporadas no design de produtos de tal forma que passarão eventualmente a ser consideradas como qualquer outro tipo de material - tal como o vidro ou os plásticos -, com o qual se poderão desenvolver soluções inovadoras e de melhor desempenho. No entanto, em oposição a esta visão de um esplêndido novo mundo de penetrante tecnologia avançada, alguns designers promovem o uso de processos mais naturais, que não só tenham um impacto mínimo no ambiente natural como também rejeitem a exigência instável da cada vez maior variedade e volume de produtos.

Em resposta à complexidade tecnológica corrente, a simplificação tornou-se claramente um objetivo-chave do design. Há poucas dúvidas de que a futura tarefa dos designers será a de conceber produtos fáceis de compreender e que possam ser usados de forma intuitiva. Da mesma forma, a simplificação da forma estrutural não só proporcionará o meio através do qual os designers poderão obter o máximo a partir do mínimo, mas também ajudará na realização de formas que possuam uma pureza emocional inerente. A simplificação no design reduzirá, assim, o ruído branco da vida contemporânea e proporcionará um dos melhores meios de realçar a qualidade dos produtos e, por isso, sua durabilidade.

Os aspectos psicológicos do design são também extensamente mencionados com uma importância sem precedentes. Há um consenso generalizado de que os produtos devem estar para além das considerações de forma e função se pretendem tornar-se "objetos de desejo" em um mercado cada vez mais competitivo. Para se conseguir isso, os produtos precisam estabelecer ligações emocionais agradáveis com seus usuários por meio do prazer da manipulação e/ou da beleza de sua forma. A emotividade é considerada por muitos dos designers não só como uma forma poderosa e essencial de facilitar ligações melhores e mais significativas entre os produtos e seus usuários, mas também um meio eficaz de diferenciar 
suas soluções das de seus competidores. Vivemos em um mundo de signos e simbologias, e esta realidade é também um dos pilares de sustentação do design. Em uma sociedade globalizada, adquire-se não apenas o objeto, mas o discurso do objeto.

De todos os temas que emergem, a tendência para as soluções individuais ou universais inclui potencialmente as consequências mais abrangentes do futuro curso do design. Enquanto alguns designers promovem o individualismo no design como um canal para a expressão criativa pessoal ou para satisfazer a exigência do consumidor por produtos individualistas, outros advogam soluções universais, que normalmente são mais sãs em termos ambientais e cuja ênfase sobre a maior durabilidade estética e funcional oferece um melhor valor em termos financeiros.

$\mathrm{O}$ individualismo no design pode ser visto como uma reação contra a uniformidade da produção em massa e, em último caso, contra a crescente homogeneização da cultura global. Mas, com o objetivo de proporcionar maior conteúdo expressivo, as soluções individualistas de design conduzem muitas vezes a custos mais elevados e obsolescência estilística acelerada. Posto isto, não é surpreendente que, como forma de abordagem do design, o individualismo se tenha mantido até agora no reino dos produtos da peça única e da fabricação por lotes, em vez de fazer sérias incursões pela produção industrial em grande escala. Apesar da discussão do individualismo contra a universalidade ter começado no início da prática do design moderno, mantém-se um paradoxo fundamental: enquanto a natureza das soluções de design universais pode por vezes ser alienada, as soluções de design individualistas continuam a ser apanágio de uma elite abastada. No entanto, as novas tecnologias têm-se tornado cada vez mais acessíveis, proporcionando talvez os meios necessários para que finalmente esses dois campos reconciliem-se. O futuro do design poderá, assim, basear-se na criação de soluções universais que possam ser eficientemente adaptadas para responder às exigências individualistas.

O debate dos designers sobre a adequação das soluções individualistas contra as universais talvez possa explicar-se por meio da 
relativa ausência de hipóteses sobre uma teoria unificada ou uma nova base filosófica de design. Enquanto muitos discutem o atrativo que poderia haver em satisfazer as necessidades de um maior individualismo no design, poucos comentam a futura viabilidade de tal abordagem com suas implicações em relação à crescente produção de resíduos. No entanto, alguns designers adotam uma visão global das preocupações correntes e a longo prazo. Na verdade, há uma necessidade crescente de que os designers vejam a si próprios como responsáveis pelas suas soluções de produto e que as desenvolvam dentro de uma compreensão do impacto ambiental de cada aspecto de sua produção, uso e eventual eliminação - do berço à cova.

$\mathrm{O}$ design de produto começa a manifestar respostas compatíveis com seu papel, recorrendo à promoção do desenvolvimento sustentado pela utilização de matérias-primas de origem certificada, cuja produção envolve a qualificação profissional local e impacto social e ambiental positivo.

As tendências atuais do design ilustram a preocupação em reverter danos causados ao planeta pela industrialização em massa dos séculos XIX e XX por meio de uma abordagem mais responsável da durabilidade dos produtos, ou seja, produtos mais eficientes em relação ao consumo de energia, com preocupações ecológicas e bens recicláveis, com baixo custo, economia de materiais e racionalização dos componentes. Mas também há uma pressão em relação à exigência de ligar o consumidor de modo mais significativo a produtos cada vez mais complexos tecnologicamente. Para este fim, parece que uma abordagem do design mais considerada e centrada no homem poderia proporcionar os melhores meios para satisfazer as necessidades funcionais e psicológicas.

Como os designers desempenham claramente um papel-chave na determinação da natureza dos produtos manufaturados, há poucas dúvidas de que eles influenciem excepcionalmente as expectativas e hábitos de compra dos consumidores. Há, consequentemente, um crescente imperativo moral para que eles tracem uma nova e melhor orientação para o design, nomeadamente uma que se concentre no desenvolvimento de soluções de necessidade real, 
humanas e sustentáveis. Ao optar pelos materiais e tecnologias avançadas, e empenhando-se ao mesmo tempo em proporcionar soluções de design simplificadas com uma ligação emocional mais fácil com o consumidor, os designers devem conseguir criar os tipos de produtos éticos e relevantes que irão ser necessários no futuro.

A qualidade da cultura material global está sendo determinada pelas ações e escolhas que fazemos agora, e por isso deve ser correto que cada indivíduo - criador, fabricante e consumidor - compreenda a necessidade de uma cultura baseada na responsabilidade, assim como deve partilhar o objetivo coletivo de construir um amanhã melhor.

A natureza dos produtos industriais é determinada por um processo de design ainda mais complexo que está sujeito a muitas influências e fatores diferentes, de que avultam as restrições impostas pelos contextos sociais, econômicos, políticos, culturais, de organização e comerciais, dentro dos quais os novos produtos são desenvolvidos, e o caráter, o pensamento e as capacidades criativas dos designers individuais ou das equipes de designers, especialistas alinhados e fabricantes envolvidos em sua produção.

A discussão sobre a cultura e a identidade de indivíduos e grupos sociais é fundamental para o entendimento do papel do design no desenvolvimento dos artefatos que compõem a cultura material e, desta forma, tornam-se os referenciais que contribuem para o (re)conhecimento dos povos e da sociedade que os desenvolvem.

A pluralidade e a dinâmica cultural das sociedades requerem um conceito igualmente plural e dinâmico de identidade no design, em que seja considerada a herança cultural dos indivíduos e grupos sociais, suas transformações e inter-relações. Nesse contexto, é necessária uma postura que considere os valores culturais fundamentais, mas que também esteja aberta às contribuições do mundo, as quais possam ser absorvidas pelas culturas locais na construção de um caminho próprio. A identidade cultural fundamenta-se na diversidade e, portanto, possui um caráter dinâmico e multidimensional, não podendo ser entendida como algo imutável, da mesma forma que a discussão sobre a diversidade cultural como expressão 
de identidade é fundamental para o entendimento do papel do design no desenvolvimento de produtos para a sociedade - diante dos imperativos de padronização e diversificação e da questão local e global que se remetem à dialética entre a uniformização cultural e a diversidade de identidades - no contexto da cultura material. Desta forma, cabe ao designer, no desenvolvimento de produtos para a sociedade mundial, contribuir para a formação de uma comunidade global, eliminando-se as rivalidades entre as nações e ao mesmo tempo preservando as diferentes identidades culturais. Desta maneira:

Configura-se, portanto, um grande desafio: perceber as diferentes realidades e necessidades dos indivíduos e grupos sociais, e buscar soluções menos egoístas e mais adequadas para o desenvolvimento da sociedade como um todo. Isto exige uma visão não reducionista e o esforço conjunto das sociedades "centrais" e "periféricas", cuja diversidade cultural não deve ser considerada como um obstáculo, mas antes uma riqueza e importante fonte estratégica para o desenvolvimento sustentável de produtos com qualidade, voltados para o bem-estar das pessoas. (ibidem)

"Pense globalmente, aja localmente." A globalização dos produtos, de acordo com Ono (idem), exige que estes se comuniquem com os mercados de maneira a transpor as barreiras culturais. Isto é, a globalização, apesar de inevitável, não ocorre de modo homogêneo. Assim sendo, ao contrário de submeter-se passivamente aos padrões impostos, deve-se buscar soluções criativas que reduzam ao máximo os custos sociais. 


\section{2 \\ DESIGN E CULTURA DE MASSA}

O que irá acontecer à cultura nacional em um mundo caracterizado pela internacionalização, convergência e globalização? $\mathrm{O}$ mundo da Internet, o qual substituiu hierarquias no conhecimento de lugares, está fazendo com que seja inevitável pensar sobre isso. Qual o futuro do design?

O futuro do design é dependente de uma contínua reavaliação do passado, dos futuros designers e do desenvolvimento da cultura e da sociedade como um todo. As necessidades dos jovens designers é que irão moldar o futuro, por meio do conhecimento do passado (seus sucessos e falhas), da história e de suas análises (ou seja, o mapa do conhecimento do passado) e, ainda, da análise perceptiva do presente e seus fenômenos.

A ideia de cultura, segundo Heskett (2008), diz respeito aos valores compartilhados em uma comunidade, o que, dessa forma, pode ser entendido como o modo de vida característico dos grupos sociais, o qual é assimilado e expressado por meio de vários elementos, tais como valores, comunicações, organizações e artefatos. Na verdade, esse conceito engloba o dia a dia dos indivíduos, estando, assim, intrinsecamente ligado ao papel do design no cotidiano das pessoas.

Designers não trabalham sozinhos, eles precisam de ordens, comissões, críticas e de quem os compreenda. A funcionalidade e 
todos os fatores de pano de fundo são condições necessárias para o sucesso, em parte individual, de um designer.

O futuro do design requer cooperação, envolvendo educação em design, organização em design, designers, pesquisadores, críticos, a imprensa, a comunidade empresarial e a pública. Também como pano de fundo estão o Estado e a sociedade.

Design e designers são, e têm sido por muitos anos, um sine qua non do sistema comercial moderno. Pensando as atividades de produção e consumo, quais necessidades e desejos as pessoas (conscientemente ou não) vão encontrar por meio de imagens, materiais e artefatos que entram no mercado e ajudam a definir quem somos nós? Nas interfaces da cultura com o design, a relação é significante em ambos os níveis, seja "alto", seja "popular". Se a cultura do consumo torna o design necessário, o progresso tecnológico o torna possível. Assim, o design carrega uma mensagem tecnológica dentro de um contexto sociocultural.

Na primeira metade do século XX, o termo "design" pode ser entendido inicialmente como sinônimo de design "moderno", embora suas características variem de acordo com qual "modernidade" está em questão, e em certas instâncias "moderno" pode, inclusive, ser expresso pela adoção de um estilo histórico.

A última metade do século XX apresentou um quadro mais complexo, caracterizado pelo tema guarda-chuva "pós-modernismo", usado como um "vale-tudo" para descrever a cultura pluralística que surgiu naqueles anos. Dentro da pós-modernidade, discutivelmente, o design tinha até um papel mais integrado. Entretanto, até mesmo com a pós-modernidade, um dos níveis de conceito sobre "design" e "modernidade" continuou a estar ligado, e isto lembrava quão difícil seria desligar um termo do outro.

Agora é muito mais fácil entender que design não tinha - e continua a não ter - nenhuma definição fixa de limites ou um ideal a ser seguido. As transformações conceituais são constantes, refletindo um cenário de práticas influenciado pelas mudanças nas ideologias e nos discursos, o qual foi afetado por seus parâmetros. Se um discurso de design pode ser desenvolvido, é preciso ser um no qual 
possa ser reconhecido o alto nível de relativismo, pragmatismo e contextualização que tem determinado o conceito passado e que irá, sem dúvida, continuar a afetar seu futuro. O design irá continuar a ser influenciado pelo consumo, pelo sistema de moda, por identidades de todos os tipos e pela produção, seja industrial ou de bases artesanais, assim como continuará sendo sustentado por ideologias e discursos fora de seu controle. Isto é um movimento contínuo, embora seu futuro seja - como tudo mais - significativamente influenciado pelo passado.

A ideia de coisas e imagens impregnadas de características estéticas e funcionais enquanto significado de atração e encontro com as necessidades dos consumidores e usuários tem uma longa história, e isso se encontra intimamente ligado ao desenvolvimento do que tem sido chamado de sociedade "moderna".

Sem dúvida, a ideia de modernidade existia antes dos arquitetos e designers criarem uma correlação visual/material no início do século XX. Havia, entretanto, vários sinais da mão humana no olhar da cidade - fosse Londres, Paris, Viena ou Nova Iorque - no final do século XIX. Tecnologia e design trabalharam lado a lado para facilitar a transformação desse impacto visual e material na construção do ambiente urbano, o qual, por outro lado, teve um efeito transformador além do esperado.

Mais significante foi o surgimento de um conceito de design definido pelos papéis em formação na modernidade. Esses novos e espetaculares "displays" eram criados por um novo "artista", criador de vitrines, cujo trabalho era dar vida a um foco visual dramático, uma armação para os numerosos flanêurs que presenciavam a transformação nas ruas da cidade. O papel da publicidade pública nessa forma de vitrines determinou o que mais tarde passou a ser chamado de "design para a indústria", e os artistas das vitrines das lojas do século XIX podiam ser vistos como antecessores dos criativos artistas do período entre guerras, conhecidos como designers industriais, que foram quem transformou a aparência das coisas.

Nesses anos de formação, os sinais em questão continuavam a incluir as tradicionais artes decorativas, as quais continham uma 
segurança da familiaridade e eram, dessa forma, livres de riscos para consumidores que estavam incertos sobre seus gostos. Como a importância dos modismos e da modernidade começou a aumentar sobre o papel da tradição, a cultura material começou a refletir esse fato. Isso foi mais aparente, em um primeiro momento, no mundo das duas dimensões das promoções comerciais, que abrangiam anúncios, revistas e embalagens criadas para os produtos. $\mathrm{O}$ desenvolvimento de um sistema de informação visual e mediação envolvendo bens de consumo tornou os consumidores atentos para o que estava disponível para eles e ajudou a plantar em suas mentes uma imagem idealizada em que suas aspirações podiam ser baseadas. O crescimento da propaganda moderna e da moderna revista de comunicação de massa, destinada em primeira instância para as mulheres, serviu para criar novos níveis de desejo e acelerou o crescimento da cultura de consumo, a qual estava impregnada da ideia de modernidade.

O significado de "valor agregado" representou um primeiro estágio no processo que se concluiu nos anos entre guerras como design industrial, em que a manufatura finalmente percebeu que o impacto visual dos bens de consumo tornava-os competitivos de uma forma que os anúncios, as embalagens e as vitrines das lojas não conseguiam.

Resumindo, nos primeiros anos do século XX, o mundo comercial estava preocupado em estimular e retribuir o desejo do consumidor desenvolvendo estratégias de marketing associadas a uma nova tecnologia orientada para um conceito de modernidade, traduzindo assim o fenômeno de novos consumidores usando cultura material como forma de definir e comunicar suas identidades e aspirações por meio da disponibilidade de mais e mais bens de consumo, imagens e serviços no mercado. Criou-se, assim, um cenário de fundo necessário para o surgimento de um conceito de design moderno - ainda que não denominado dessa forma e apenas definido por uma extensão significante de seu papel dentro do consumo conspícuo e das exigências socioculturais do mercado -, o qual era caracterizado por suas possibilidades únicas na interface entre consumo e produção. 
E assim, nos anos entre as duas guerras mundiais, a Modernidade era um conceito sem limites. Apontava para uma extensão onde as pessoas podiam imaginar o futuro e trazer essa visão para o presente. Isso era frequentemente experienciado como um conceito aspiracional, algo que prometia um nível de "valor agregado" na vida das pessoas que ia além da "necessidade" para o mundo do "desejo".

Talvez as características-chave da Modernidade, o modo como foi apresentada aos consumidores do mundo industrializado, foram suas ambivalências e contradições. Inevitavelmente, os designers, pagos para serem imaginativos e visualmente inovadores, tinham uma parte-chave nesse processo de desenvolvimento de vários modelos de modernidade, e assegurando isso, sendo constantemente renováveis e renovados.

Durante os anos entre guerras, a cultura visual e material projetada para o consumo, abraçando, assim, a modernidade, tornou-se um dos principais meios através do qual a maioria dos habitantes do mundo industrializado adquiria sua identidade e posicionava-se na sociedade. E foi com a intensificação e a expansão desse processo que os designers acharam-se não mais ao longo das margens, mas no epicentro da moderna cultura de consumo.

Enquantoum processointrínseco de massificação da manufatura, assim como um fenômeno que comunicava valores socioculturais, o design, entendido como o divisor da tecnologia e da cultura, era embutido igualmente e firmemente no mundo do consumo e da produção. De fato, isso era uma das forças determinantes que ajudavam a conectar-se a esses dois mundos e, ao mesmo tempo, fazer uma conexão entre eles.

Para entender o papel do design no contexto sociocultural do consumo, é também importante apreciar sua posição dentro da história das mudanças tecnológicas, assim como o que ele afeta e pelo que é afetado na manufatura e no mundo dos materiais. Na virada do século XIX para o século XX, as inovações tecnológicas e os novos materiais desafiavam e excitavam a imaginação dos designers, assim como constituíam-se em uma nova área de cultura material. 
O advento da cultura do consumo de massa também requereu que novas tarefas fossem empreendidas pelos designers, que tinham uma única perspectiva no mercado. Como resultado, o design emergiu como uma nova atividade, ou melhor, como uma nova combinação de atividades. Em resposta às transformações sociais que a industrialização trouxe consigo e à segurança para a cultura material carregar novos significados socioculturais, o design combinava um novo cenário de atividades, as quais cruzavam a divisa produção/consumo. Por conseguinte, isso foi colocado para representar a noção de "modernidade" e como isto relacionou ambas as arenas.

A distinção entre invenção e design era bastante clara. Enquanto o papel dos inventores era criar novas aplicações para as tecnologias disponíveis, o designer atuava como a interface entre essas aplicações, a indústria manufatureira e os consumidores. E, ao longo do século XX, essa descoberta de novos materiais e inovações em produção tecnológicas constantemente desafiou designers a encontrar formas e significados para tal descoberta.

O trajeto tecnológico e econômico para a frente era necessariamente mediado pela aceitação do consumidor, mas as agressivas técnicas de vendas empregando propaganda e design eram arejadas como um significado de "desejo" criativo e que aumentava o apelo moderno dos materiais em questão. $\mathrm{O}$ design atuava como uma importante ponte entre a tecnologia e a cultura, antecipando a demanda de consumo e fazendo novas tecnologias e materiais, ambos disponíveis e desejáveis no mercado de massa.

O impacto cultural de novos materiais, auxiliado pelo design, foi uma contribuição altamente significativa para a modernização da vida de um grande número de pessoas nos anos entre guerras. Ambos, a materialidade do novo modo de vida e a maneira como esses novos produtos "avulsos" eram "catapultados" na vida cotidiana, aparentemente intocados pela mão humana, proveram consumidores com um novo jogo de experiências determinado pela cultura em lugar de pela natureza, o que levava a humanidade um passo mais distante do mundo que tinha se tornado inabitado depois que a industrialização mudou as coisas para sempre. 
Como parte de um quadro que vinha se desenvolvendo desde o ano 1914, pode-se notar o surgimento de uma nova "raça" de visualidade treinada, ou ao menos visualmente atenta: indivíduos que podiam prover de opções estéticas, baseadas nas quais os consumidores podiam fazer suas decisões de escolha. Com o crescimento acelerado do consumo, que foi trazido pela possibilidade de "conspicuidade" para um setor expandido da sociedade, e com as indústrias de produção em massa tendo reorganizado suas operações, assim como seus produtos, imagens e serviços ao gosto requerido pelo mercado de massa, tornou-se praticamente imperativa a necessidade de clarificar a natureza do processo de design e o trabalho dos indivíduos envolvidos.

Se o design era para ser a força harmonizadora entre a sociedade que queria expressar-se por meio do gosto e a tecnologia que aspirava ultimar racionalidade e eficiência, isto precisava educar a criatividade individual de quem podia entender os dois lados da equação.

Por volta de 1914, o design lembrava uma atividade muito diversa e indefinida. De fato, não era uma atividade isolada, mas consistida de um número de práticas com diferentes filosofias e trato profissional, em sintonia com o trabalho dos operários fabris, engenheiros, decoradores, artistas, arquitetos e publicitários. Apenas retrospectivamente uma linha única pode ser traçada através dessas práticas variadas, cujos praticantes, naquele tempo, ignoravam a existência uns dos outros. Entretanto, eram sinais de um conflito emergente entre aqueles que se autodenominavam "operadores" dentro do sistema comercial e aqueles (na maioria arquitetos) que tinham um ponto de vista mais idealista sobre seu envolvimento com a criação da cultura material. Mas ambos os grupos viam suas participações na elaboração estética dos objetos cotidianos e suas imagens. Nos anos entre guerras, as duas abordagens estavam abertas uma à outra. Sob o manto do progresso, arquitetos e outros abraçaram a face comercial da cultura material.

Antes de 1914, a atividade de design - mesmo que não fosse assim denominada - estava firmemente estabelecida, e seus aspectos 
fundamentais eram as indústrias manufatureiras e os contextos comerciais, ou seja, criação/desenvolvimento de bens de consumo e suas respectivas imagens. Entretanto, enquanto um indivíduo com uma ocupação especificamente definida, o conceito de designer ainda não existia.

O link entre a social democracia e o design relembra uma constante articulação dentro de um quadro de princípios do design moderno que emergiram em várias nações, entre elas a Alemanha, a França, a Holanda e a Escandinávia, nos anos entre guerras. Explícita e implicitamente, ambos eram considerados como sendo interdependentes. Essa crença de que o design estava ligado à ideologia da social democracia explica a hostilidade que era frequentemente expressada pelos escritos modernistas, e isso fazia ter sentido o forte comprometimento manifestado em todos aqueles países para com a moradia social; o conceito de mínimo espaço e seu mobiliário, e o significado da estandardização em fazer mais barato e objetos funcionais para todos. Como se isso fosse um elemento intrínseco à campanha modernista para uma sociedade igualitária com acesso a moradia e bens de consumo. Assim como foram ligadas às mudanças sociais e políticas, as qualidades do racionalismo e do idealismo que sustentavam o modernismo eram especialmente aparentes na educação dos designers.

Nos anos 1930, a aparência da arquitetura e do design moderno era limitada a uma audiência que apreciava essa mensagem subliminar. A encarnação da moradia social podia ser vista como um estilo que foi imposto por uma classe sobre a outra. Em termos gerais, isso tinha limitado o apelo de mercado, especialmente no contexto doméstico.

Era evidente, por volta de 1914, uma sofisticada compreensão da forma como a cultura material projetada podia ser manipulada e usada por grupos, instituições e nações, de modo a forjar identidades e comunicá-la a um grande número de pessoas. Grupos de interesse de todos os tamanhos, concentrados em persuadir outros de seu status e autoridade, começaram a usar artefatos projetados e imagens como uma forma de se expressar e tentando persuadir ou- 
tros a acreditar no que eles acreditavam ser seu econômico, político, tecnológico ou cultural preeminente.

Em nenhuma parte esse processo foi mais aparente nesse período do que nas nações emergentes, que usaram o design como um significado de formação, expressão e promoção de suas identidades individuais para si mesmas e para o mundo. As estratégias empregadas para ligar cultura material com identidade nacional eram essencialmente duplas. Elas envolviam um olhar para as tradições da produção artesanal vestida com as luzes das preocupações atuais, ou saltando com fé dentro do futuro e desenvolvendo um programa "arte dentro da indústria", o qual propunha novas formas e modernas identidades apropriadas à idade da máquina. Inevitavelmente, as duas estratégias frequentemente se sobrepunham, e a distância entre elas se tornava nitidamente obscurecida.

A aliança entre design e programas nacionais de reforma e competição internacional foi largamente observada durante o século XX. A manipulação ideológica da cultura material e dos espaços projetados e caracterizados nas numerosas exibições ocorreu em todo o mundo industrializado durante os séculos XIX e XX. O design representou um papel significativo, notadamente pela presença de objetos de arte decorativos, produtos da nova indústria e realizações da engenharia nas áreas de nova tecnologia.

A virada do século XIX para o século XX presenciou transformações no mundo material como nunca tinham sido vistas até então. Foi nessa época que nasceu o que hoje se entende por "Idade Moderna”. A vida das pessoas, e não apenas daquelas que viviam no mundo industrializado, mudou de modo irrevogável. $\mathrm{O}$ advento do transporte de massa, da comunicação de massa e da produção em massa de bens de consumo alterou as coisas para sempre. A força dominante atrás dessas mudanças foi a tecnologia, aparentemente racional, progressiva, mas sobretudo impossível de ser detida. Várias pessoas tinham fé de que esse seria o caminho a ser seguido. Para quem acreditava, ia ser um caminho repleto de progresso material, igualdade social e eficiência racional na resolução dos problemas cotidianos. 
De várias maneiras, a Primeira Guerra Mundial foi um divisor de águas na evolução do design moderno. Por volta de 1914, o Art Nouveau já não era um movimento de design e havia se transformado em um estilo da moda. Havia, entretanto, outra abordagem em design, baseada no pensamento do Arts and Crafts, com uma nova simplicidade e atitude racional, que tinha por ponto de partida os materiais empregados e suas características surgidas depois da Primeira Guerra Mundial, ponto este conhecido como Funcionalismo. Os anos pós 1918 viram essa abordagem tornar-se a base da racionalidade para uma arquitetura e um design radicais, os quais, até a Segunda Guerra Mundial, tiveram grande impacto internacional. Duas faces do Modernismo emergente, uma extremamente progressista e outra mais orientada historicamente e conservadora por natureza.

Por volta de 1914, era evidente que a cultura material projetada era importante na formação e comunicação de um grande número de identidades nacionais, especialmente na Europa. Isso tinha um significado importante, pois governos e corporações podiam definir seus cidadãos e seus consumidores, que podiam definir a si mesmos. A identificação nacional nessa época adquiriu novo significado: o de expressar-se nas modernas, urbanizadas e altamente tecnológicas sociedades.

A mass media do entre guerras - a impressa, o cinema e o rádio tinha o poder de padronizar, homogeneizar e transformar ideologias populares, assim como de explorá-las para seus propósitos de propaganda deliberada pelos interesses privados e estatais. Por meio da produção industrial em massa e de outras formas de reprodução (fotografia, por exemplo), projetar imagens e objetos tinha se constituído em um componente importante da mass media, capaz de representar o mesmo significado das formas que o acompanhavam. De fato, por meio dessas múltiplas manifestações - enquanto representações, imagens, artefatos, espaços e ambientes -, o design era mais eficiente do que outros aspectos da mass media, comunicando valores e ideias de um modo persuasivo.

No final dos anos 1930, o design tinha se tornado uma ferramenta disponível para ser usada tanto pela iniciativa privada como pelas 
nações para persuadir outros tantos a consumirem seus produtos ou reconhecer sua autoridade. Como uma forma de propaganda tanto econômica como política, isso tinha um potencial enorme. Era capaz de transmitir valores que encorajavam consumidores a comprar produtos e imagens como uma forma de formação de identidade. O mesmo poder de persuasão e as ofertas de identidade podiam ser usados por regimes políticos para encorajar a lealdade nacional. Dois países que usaram efetivamente o design para representar a si mesmos como nação foram os Estados fascistas da Alemanha e da Itália. Ao contrário do rádio e de outras formas de mass media, o design podia trabalhar em várias camadas, tais como os significados das comodidades e imagens, já codificados pelos designers, ou ainda podia ser representado por outros designers dentro do contexto de código duplo de uma exibição, de uma vitrine, de uma folha impressa ou de uma campanha publicitária. Durante os anos entre guerras, várias nações e corporações tinham começado a depender do design para seus fins comerciais ou ideológicos, e eram completamente atentas a esse potencial tanto de persuasão como de preencher necessidades e desejos.


Figura 3 - Como exemplo, vale a pena lembrar o papel desempenhado pelos designers americanos, principalmente Raymond Lowey, dentro do New Deal, e, ainda, Hitler e a criação do Volkswagen. 
O Art Deco promoveu uma noção elitista de luxo e uma ideia de qualidade derivada de habilidades artesanais e do uso de materiais caros, assim como o Art Nouveau, mas foi gradativamente transformado em um estilo popular, sendo que, por volta de 1930, tinha penetrado no ambiente de massa de uma forma sem precedentes, de seu início nos luxuosos transatlânticos franceses até chegar a adornos de fachadas de fábricas e cinemas, tornando-se um estilo popular em todo o mundo, com seus objetos plásticos de produção em massa, de aparelhos de jantar a louça para piquenique. Começou a vida como um fenômeno exclusivo e, ironicamente, após a Segunda Guerra Mundial, tornou-se um estilo popular da idade moderna.

O mesmo já não aconteceu com a outra face do Modernismo, a face que se manifestava o mínimo em um estilo visual. Os países escandinavos, por exemplo, todos com fortes tradições folclóricas e/ou artesanais, nesse momento encontraram uma forma nova para os objetos decorativos - cerâmica, vidro, mobiliário, entre outros -, pelos quais eram bem conhecidos no mercado internacional. Em adição a essa ambição, entretanto, estava um forte comprometimento com a ideia de igualdade social por meio do design moderno aliado à produção industrial em massa, que poderia prover a oportunidade para todos melhorarem suas condições materiais de vida.

Neste momento, o design do século XX estava preocupado com a reputação reacionária do Modernismo, e assim foram permitidas adições decorativas e a incorporação do tradicional, materiais familiares, em lugar de sua marca mais rígida que influenciou e continua influenciando nossa vida cotidiana.

A metáfora predominante para o design moderno na primeira metade do século XX era, sem dúvida nenhuma, a máquina. Percebida como um poderoso e perpetuador símbolo do progresso, da democracia e do controle sobre o mundo natural, a máquina estimulava a imaginação de vários arquitetos e designers que viviam em países industrializados e respondiam ao chamado urgente de renovar constantemente o ambiente. Isso foi mais aparente nas três primeiras décadas do século XX. Dentro do clima de mudanças culturais, políticas, econômicas e tecnológicas estavam também a ideia 
e o fato de que a mecanização inspirava o trabalho experimental de uma forma sem precedentes.

Ao final da Primeira Guerra Mundial, os países europeus envolvidos no conflito estavam empenhados em criar um novo mundo democrático no qual o desenvolvimento material tinha papel vital. Vários arquitetos e designers viram uma oportunidade de aplicar seus dotes visuais e intelectuais ao gosto da criação de um novo modo de vida para a massa populacional. Ao final, eles combinavam as inovações fazendo-as possíveis para a produção em massa - como o pioneirismo norte-americano na indústria automobilística - com as inovações estilísticas que arquitetos e designers progressistas vinham fazendo desde o início do século baseados nos princípios da abstração e da simplificação geométrica. Pela primeira vez essas forças estavam adicionadas em uma poderosa fórmula para um novo movimento em design, um movimento essencialmente idealístico por natureza e baseado na necessidade de mudança e renovação.

Essas abordagens em design moveram-se da arquitetura para as artes aplicadas - mobiliário, cerâmica, vidro e trabalhos em metal e têxteis - e eventualmente para o desenho industrial, e ao final dos anos 1920, o Modernismo tinha se tornado um ideal internacional, representado em numerosos eventos. Inevitavelmente, o idealismo do movimento significava que o esforço individual dos protagonistas falhou em atingir a massa de modo significativo. Entretanto, sua influência foi sentida de várias maneiras tangíveis, como, por exemplo, na presença de ferro tubular em mobiliário escolar e hospitalar em todo o mundo. A influência do Modernismo foi mais importante em um nível teórico, onde dominava em revistas internacionais e coleções de museus.

Embora a maioria dos esforços pioneiros estivesse na Europa, os Estados Unidos não estavam imunes aos efeitos do que se tornou conhecido como Movimento Moderno na arquitetura e no design. Esse país também foi a pátria do movimento mais comercialmente orientado em design que houve, com impacto internacional nos anos pós-guerra. Enquanto os europeus limitavam-se principalmente à arquitetura e às artes aplicadas, os "desenhistas 
industriais" americanos repaginaram drasticamente o mundo dos refrigeradores, das caixas registradoras, das máquinas fotográficas e, por último, mas não menos importante, dos automóveis. Com experiência em propaganda e vitrines, esses designers não estavam ideologicamente direcionados como os europeus. Sua missão era a modernização do ambiente popular.

Em 1939, ano da Feira Mundial em Nova Iorque, a máquina moderna dominava a vida tanto nas fábricas como no trabalho doméstico, possibilitando a todos acreditar que poderiam participar do futuro. Os designers tiveram um papel fundamental na concretização dessa possibilidade.

AtéaSegunda Guerra Mundial, odesign domovimentomoderno, nas suas mais variadas formas de manifestação, estava formado e sua influência era sentida internacionalmente tanto em níveis reais como ideológicos. Essa credibilidade foi plenamente articulada, e seus pioneiros, reconhecidos. Depois de 1945, os designers tinham uma tradição moderna para trabalhar com ou contra, e líderes para serem seguidos ou rejeitados.

O mais sofisticado caminho para o progresso do design no pósguerra na Europa foi a questão das identidades nacionais. Várias das nações que precisavam se reconstruir após a Segunda Guerra Mundial queriam projetar uma nova imagem de si mesmas no mercado internacional, e o design configurou-se com um caminho através do qual isso poderia ser feito, pois, de acordo com Heskett (idem), "objetos e ambientes podem ser usados pelas pessoas para formar uma ideia de quem elas são e para expressar sua noção de identidade”.

Na Europa, isso foi mais visível na Escandinávia, na Itália, na Alemanha e na Grã-Bretanha. Os Estados Unidos e o Japão também utilizaram o design moderno para ilustrar o progresso de suas economias e culturas, e posteriormente os países que foram libertados com a desintegração do império soviético no final da década de 1980 .

Os Estados Unidos foram representados pelos objetos aerodinâmicos, os quais foram exportados para vários países em todo o mundo. Em resposta, vários países europeus reformularam suas 
próprias tradições, cada qual a seu modo. Na Escandinávia, por exemplo, a tradição artesanal foi reformulada sob a luz dos prérequisitos da modernidade como um significado de sua própria identidade. Todos os países em questão procuraram promover suas próprias imagens de good design nesse período, e várias estratégias diferentes foram adotadas para tornar isso possível.

No sonho da modernidade pós 1945, o conceito de design começou a ser ligado com o de "modernidade" traduzido no design norte-americano do pós-guerra. Isso se explica mediante uma "americanização" da Europa no final dos anos 1950, presente na democratização da expressão de "gosto", nas pessoas que desejam melhorar sua condição material/social, em uma nova identidade nacional, no materialismo e no consumo de massa e, ainda, nos filmes, na TV, nos seriados e na propaganda.

Assim como nos anos pré-guerra, também depois de 1945 o design continuou a carregar consigo o potencial de representar as nações e seus desejos de projetar suas identidades no mundo como um todo. Exemplo disso é a influência da Bauhaus somada ao modelo americano de produção em massa. $\mathrm{O}$ resultado foi um casamento de sucesso do cultural e do comercial que produziu fortes identidades para os produtos.

O consumo da moderna cultura material tornou-se o significado primário da formação de identidade e uma manifestação de aspiração social para a maioria das pessoas no oeste industrializado nos anos 1950 e 1960. E, mais importante: para os novos consumidores em particular, a ênfase estava no consumo do moderno (produtos e imagens).

Os consumidores eram gradativamente introduzidos não meramente ao design moderno, e sim ao conceito, mais particularmente de "good design". O visual e material equivalente que eles eram encorajados a usar quando comprassem, em outras palavras, "bom gosto". Em um nível, esse espírito de reforma do design, forte desde meados do século XIX, pode ser visto como uma resposta ao rápido crescimento do consumo que envolvia "não educados" setores da população. O receio de ser infectado pelo "kitsch" ou pelo "mau de- 
sign", associado com um descontrolado mercado que estava atento a uma sociedade ordenada, era experienciado internacionalmente.

A necessidade de uma face "supercultural" do design nos anos pós-guerra está relacionada ao desejo de uma parte da classe média, interessada em distinguir-se, por meio do exercício do "gosto educado" no ato de consumo, dos consumidores da cultura de massa.

Não foram apenas as nações que rapidamente utilizaram a retórica visual e ideológica do design como um significado de criação de identidade instantânea nos anos depois de 1945. Companhias multinacionais também viram no design o potencial para definir identidades globais que poderiam habilitá-las a controlar esses mercados. Segurança sueca, eficiência tecnológica alemã, idiossincrasia francesa, elegância italiana... No mercado internacional, cada imagem representava quase uma caricatura da identidade nacional. Era o design semântico em sua riqueza, a criação de um cenário de linguagens de design que comunicavam aos consumidores mais do que apenas "aptidão para o propósito" nos produtos que acompanhavam.

O embasamento do design moderno do pós-guerra para esses diversos tipos de democracia surgiu após 1945. O cenário do Modernismo pré-guerra deu o tom, e o design moderno, após essa data e o ideal de objetos bem projetados, foi avaliado caso a caso.

Os anos 1950 viram os bens de consumo atravessar o Atlântico, dos Estados Unidos até a Europa. Houve um espantoso e crescente interesse por objetos feitos com materiais modernos, os quais eram vistos como sinais de um novo estilo de vida, com consumidores em todo o mundo querendo representar suas aspirações pessoais nos interiores domésticos. O interesse sem precedentes nas variações do estilo moderno disponíveis no mercado encorajavam os designers a criar mais escolhas e as manufaturas a produzir uma grande variedade de coisas.

Assim como nos anos pré-guerra, a década após 1945 assistiu ao sucesso internacional do pioneirismo individual. Todas as correntes estilísticas foram disseminadas internacionalmente. Novos materiais, particularmente a madeira compensada, tornaram possível 
aos objetos exibir uma nova expressividade, enquanto os avanços em eletrônica liberavam o consumidor de maquinário para tornar-se estilisticamente sofisticado. Enquanto objetos relacionados com a decoração doméstica tendiam a mover-se em direção às formas orgânicas, rejeitando a máquina em favor de formas abstratas derivadas do corpo humano e do mundo da natureza, empresas como a Braun ou a Sony definiam a si mesmas como caracterizadas por suas virtuosidades tecnológicas.

Designers tornaram-se mais e mais adeptos da tese de construir novos estilos para os objetos, conscientes de que aquele era o significado dos objetos, e não apenas os princípios subliminares, que importava. Com o consumo de massa do estilo moderno, as possibilidades tecnológicas sempre em expansão e a natureza global do mercado que ocorreu no final dos anos 1950, abriram-se para os designers várias possibilidades. Evidentemente que o design moderno estava completamente integrado na economia capitalista da segunda metade do século XX, e tornou-se uma das maiores forças culturais do período.

Os anos 1960 caracterizam-se como ponto culminante dessa cultura de massificação de consumo que vinha se desenhando desde o pós-guerra com a crise e a revisão da modernidade e uma nova fase na relação entre design e cultura. A cultura foi redefinida e encorajada a abraçar grupos sociais e culturais diferentes e dar vozes iguais a todos. O design foi forçado a quebrar suas primeiras ligações com a modernidade, abraçar uma abordagem mais pragmática, orientada para o mercado popular, ${ }^{1}$ ignorar a linha que tinha separado "alta cultura" de seu popular equivalente. E os anos 1970 vão assistir ao revival do artesanato e do uso do vernacular.

Mais do que nunca, design e designers alinharam-se com a mass media e tiveram um papel central dentro da construção dos numerosos estilos de vida que eram oferecidos. Esse novo caminho de comunicação com os consumidores significava que, para um de-

1 "I prefer 'both-and' to 'either-or', black and white, and sometimes gray, to black or white." 
terminado mercado, o design tornava-se um aliado muito próximo dos processos de marketing, com o aspecto visual dos produtos, das imagens e dos espaços incrementando a dependência da comunicação da mensagem instantânea, na qual havia uma unidade entre imagem e criação, traduzida, por exemplo, na agregação de valor ao nome do designer e no papel desempenhado, por meio do consumo, do designer (discurso do objeto) como formador de identidade, em ambientações nostálgicas cenográficas, tais como reconstrução do passado por meio do presente: "Living in an old country", e, ainda, a hiper-realidade, mais interessante que a própria realidade, mais viva e colorida, remasterizada.

As manufaturas continuavam a direcionar seu mercado para grupos específicos, mas gradativamente estes começaram a ser definidos menos pela identidade geográfica, pela classe, pelo gênero ou pela idade do que pelos gostos culturais, valores, estilo de vida e tipos de personalidade. Assim, o design transforma-se em uma experiência cotidiana, do shopping ao turismo. Os designers tinham encontrado um papel para si mesmos que era inexpugnável. As novas tecnologias e os novos materiais no pós-guerra eram agora iguais a novos objetos.

Em 1960, o desejo democrático inicial dos modernistas de usar produção em massa para tornar bens materiais disponíveis para todos foi substituído pelo reconhecimento de que o design foi um símbolo importante do modernismo e, em termos sociais, um marco de sofisticação da consciência cultural. Como consequência, os designers tiveram a grande responsabilidade de encontrar adequadamente aqueles requisitos simbólicos e de criar bens que poderiam representar esse papel.

O otimismo que os países mostravam por meio da produção em design nos anos 1960 refletia o cume do boom de consumo do pósguerra. Os ideais do design estabelecidos antes da Segunda Guerra Mundial foram reorganizados e reformulados para encontrar as mudanças nas necessidades sociais e psicológicas de uma nova audiência que via o design moderno como uma forma de identificar a si mesmo com o presente e, mais importante, com o futuro. 
Entretanto, não eram como os primeiros Modernistas, com seus fortes comprometimentos ideológicos, que tinham sido identificados com malícia e exclusividade por vários designers dos anos 1960. Progressivamente, estes vieram a estar em pé de igualdade com o alto nível de consumo elevado que caracterizou aqueles anos. Enquanto vários designers encaminhavam-se para o campo de criação de bens de visualidade inovadora que recheavam as revistas, outros começaram a sentir que um tipo de traição estava surgindo.

Essa situação que surgiu repentinamente em meados dos anos 1960 foi estimulada por um número de elementos convergentes: o surgimento de um mercado consumidor jovem, acompanhado da ênfase na diversão e no tempo livre tendo um papel-chave, ajudando a minar o sistema de valores, baseado nas ideias de racionalidade e universatilidade, que tinham baseado o Movimento Moderno. A nova estética Pop priorizava o descartável e o temporário. O foco em valores de consumo teve um enorme impacto nas ideias prévias sobre design, e em meados dos anos 1960, um novo radicalismo emergiu no mundo. Agora o design, abertamente, tirava sua inspiração da cultura popular. Não foi a primeira vez que isso aconteceu, mas representou um desafio real para os valores do Modernismo, que tinha dominado os ideais do design através do século XX. O trabalho dos consultores norte-americanos para a indústria nos anos 1930 embasou a ideia do design baseado no sonho popular e na aspiração, e a estética aerodinâmica tinha tido pouco em comum com a elite cultural.

Na década de 1960, entretanto, uma divisão fundamental - a qual existia desde o início do século, quando o maquinário da produção em massa mudou os ideais dos heróis do Movimento Moderno para estilistas de opções de consumo - tornou-se aparente, com designers abertamente desafiando a relevância do Modernismo no mercado de massa. E, em meados da década, o mundo do design claramente percebeu que de fato o Modernismo estava em crise. Os avanços tecnológicos ajudaram a "por lenha na fogueira". Desenvolvimentos em eletrônica fizeram os componentes dos produtos tão pequenos que não era mais necessário que seus invólucros refle- 
tissem o funcionamento de seu interior. Nas mãos dos designers, os produtos gradativamente tornaram-se acompanhamentos do estilo de vida, objetos de moda, e as teorias do Funcionalismo tornaram-se, por consequência, redundantes.

Todavia, não muitos designers corresponderam. A maioria havia sido, e continuava a ser, educada dentro da tradição do Modernismo e estava relutante em abandonar suas crenças confortáveis e persuasivas. Um comprometimento com valores, qualidade e regras de função dificultava, e de fato para muitos era até indesejável, juntar-se ao que começava a parecer com a nova era "PósModerna" em design. Poucos estavam preparados e desejosos de refletir o novo impulso em sã consciência.

Por volta de 1970, novos materiais e técnicas de manufatura tinham transformado a face do mundo cotidiano, fazendo-o muito mais diferente do que trinta anos antes. Na linguagem do modernismo utópico, o poder da tecnologia era prover um mundo melhor, e o design, com um papel mediador, interfaceava alternadamente com a tecnologia, assegurando que tecnologia, se expressada por meio da cultura material, comunicava mensagens apropriadas. A fé no poder da tecnologia em transformar o tempo livre era expressa na linguagem estética nascida da própria tecnologia.

Nos anos 1970, chegou ao fim a dominação de um único movimento internacional em design. Por um lado, o Modernismo continuava sob ataque e a ser largamente desacreditado, e por outro, modernistas contemporâneos apareciam para provar a validade desse movimento, para nos persuadir que, mesmo com as mudanças das condições econômicas, sociais e culturais, o impulso do progresso tecnológico poderia nos levar para um futuro brilhante. Como no início do Modernismo, o debate mais acalorado ocorreu na Arquitetura, seguida pelo Design. O que era evidente nesses debates é que, ao menos estilisticamente, existiam alternativas para o Modernismo, e mais importante, encaminhando-se para o pluralismo.

Enquanto os arquitetos discutiam a validade do estilo do diatal qual seus predecessores no século XIX -, os designers também tinham outras coisas a considerar. Entre elas estavam o efeito da 
crise do petróleo no custo dos plásticos e o crescimento do interesse da sociedade em abordagens ecológicas, assim como em reciclagem. Essa foi a ênfase em que o debate fugiu da discussão sobre estilo e sugeriu um papel social mais sério para os designers em termos de relação com a indústria manufatureira. $\mathrm{O}$ senso geral de desilusão com a tecnologia e tudo que ela tinha prometido também contribuiu para desestabilizar as premissas nas quais o design moderno tinha se baseado. Embora o design tivesse um papel decisivo neste processo - assegurando que as formas nas quais a tecnologia buscava usuários estavam visualmente e simbolicamente adequadas e usáveis -, era sem dúvida a tecnologia quem dava o tom, e os designers seguiam-na, criando caixas atrativas para os complexos eletrônicos que iam dentro delas. A tecnologia também transformou a natureza das imagens, dos bens de consumo e dos serviços e trouxe consigo a reação dos consumidores. Os designers tiveram de responder a esses desafios que apareciam e redefinir seus papéis e práticas à luz de tais desafios.

Em adição à transformação do processo de design por si só, novos métodos de manufatura foram introduzidos nas últimas décadas do século XX, fazendo uma grande diversidade de bens de consumo disponíveis no mercado.

Ainda que os novos materiais do início do século XX - entre eles concreto, aço e vidro - tivessem sido compreensíveis, em termos de produção, para essa audiência de consumidores, a crença de que o funcionalismo precisava dos designers para encontrar expressões visuais para os materiais com os quais eles estavam trabalhando deu a esses profissionais um nível de liberdade estética indisponível dentro do Modernismo. A combinação da perda dessa possibilidade de compreensão, o uso dos sistemas automáticos de produção e o surgimento dos eletrônicos e produtos digitais significavam que a regra de ouro do modernismo - forma segue a função - tinha finalmente perdido toda a relevância, mesmo metaforicamente, e não mais podia ser implementada significativamente pelos designers. Em seu lugar estava uma nova oportunidade para os designers criarem objetos, serviços e sistemas que ofereciam aos consumidores 
novas identidades e novos significados, os quais eram ligados a essas identidades e que dependiam mais pesadamente da cultura do que da tecnologia, contexto no qual eles se encontravam. Isso também providenciou um espaço para designers pensarem sobre novas funções para artefatos, particularmente na área de necessidades físicas e sociais.

Com os novos campos de atuação nos anos 1980 e 1990, o público tornou-se progressivamente atento a um conceito cultural chamado "design". Nos anos 1990, a cultura do design estava completamente integrada na cultura de massa, com designers apresentando o mesmo nível de significado que aquelas celebridades do cinema ou da TV. Chamada de "a década do designer", os anos 1980 apreciaram outro tipo de boom de consumo, e o agora democrático conceito de design teve um novo significado nesse contexto. A palavra "design" foi rotulada como qualquer comodidade que promovia a si mesma como especial, de cabeleireiros a jeans. Nesse contexto de mercado de massa do final do século XX, o termo "designer" implicou um nível de individualismo e gosto que estava ressurgindo para pessoas que queriam ser diferentes. Enquanto apenas estratégia de marketing, um dos efeitos foi a popularização do conceito de design e designers. Estes se tornaram celebridades na mesma ordem dos desenhistas industriais norte-americanos dos anos 1930. Não apenas a Europa, mas também o Japão, a Coreia do Sul, Singapura e Taiwan estavam aprendendo os benefícios de se ter uma cultura avançada em design.

Apesar de esses desenvolvimentos trazerem ao designer um maior destaque, garantindo um lugar na hierarquia cultural ao lado dos arquitetos e artistas, isso também teve o efeito de alinhar o conceito de design muito perto da propaganda e do marketing. $\mathrm{O}$ efeito disso foi não dar importância ao mais fundamental papel como um elemento dentro do processo de produção e como parte do ambiente material cotidiano. Quando a bomba estourou, e cultura em design, junto com a economia, teve uma baixa no início dos anos 1990. Os designers tiveram de pensar em caminhos para superar a superficialidade que havia caracterizado a década de 1980. 
Os efeitos libertadores do início dos anos 1980 ainda eram sentidos, e era possível para os designers trabalhar fora dos preceitos do Modernismo, mas agora com uma maturidade dos modelos à disposição. Por outro lado, os valores inerentes ao início do século voltaram à cena com o reconhecimento de alguns designers do contínuo significado daqueles primeiros ideais. Agora não havia contradições, porque, sem nenhuma teoria em design dominante para reagir contra, cada abordagem podia ser julgada por seus próprios méritos. Alguns designers ainda queriam um nível de celebridade, outros preferiam uma abordagem mais nos bastidores. A maioria entendeu as urgências ecológicas e incorporou isso às suas visões. Acima de tudo, o design mundial ao final do século XX tornou-se global, com uma consciência de que não era mais possível pensar apenas em termos locais ou de identidades nacionais. De um início modesto nas mãos de alguns poucos indivíduos que procuram criar e melhorar o mundo material que refletia a idade moderna, o design floresceu para uma força que afeta praticamente todo aspecto da vida moderna.

Dentro dessa capacidade enquanto força cultural, com o potencial de preencher a lacuna deixada pelas relações sociais tradicionais, o design teve claramente um papel fundamental dentro da vida cotidiana no final do século XX. Assim como uma ferramenta para carregar o poder das nações, tem transcorrido um longo caminho desde as exibições do século XIX que lotavam pavilhões com os primeiros produtos mecânicos. A identidade nacional tem se tornado uma espécie de vitrine no mercado. Isso vem embutido na mass media e experimentado em bases diárias. Como indivíduos, consumidores têm aprendido a negociar suas identidades e seu senso de "pertencimento", cientes de que isso foi feito de vários elementos definidos por múltiplas categorias, incluindo gênero, idade, etnia, estilo de vida e localidade. Ajudados pelo consumo de bens, serviços, espaços e imagens projetadas disponíveis a qualquer momento no mercado, indivíduos podem negociar suas próprias identidades e ter papel como parte ativa na construção do cotidiano da vida moderna, ou mesmo pós-moderna. 
$\mathrm{Na}$ verdade, o uso do design como ferramenta pelos Estados e pelas corporações para projetar suas identidades já era utilizado desde o século XIX, com as feiras mundiais. O papel do design na criação de identidades do lugar - de nações em particular - vinha acompanhado, em parte, pela formação das identidades globais, as quais, embora ligadas originalmente a localidades específicas, eram usualmente experimentadas "em casa". A globalização da produção e do consumo era inevitável, seguida pelo mesmo processo que tinha acontecido na profissão de designer. Entretanto, segundo Heskett (idem), "a influência que as diferenças culturais exercem na prática do design é um dos maiores problemas decorrentes do avanço da globalização". Desta forma, surge uma necessidade ao se fazer design global: avaliar até que ponto a identidade cultural está consolidada e até que ponto suporta mudanças.

Nas palavras de Ono (2006), símbolos de "identidade emprestada", "roubada" ou "permutada", via de regra, são apropriados por povos cujos referenciais culturais são pouco consistentes. Tal "manipulação de identidades" tem conduzido a conceitos equivocados de "identidade nacional", promovendo o desenvolvimento de "objetos de arte turística e/ou de aeroporto", como, por exemplo, toda a sorte de objetos artesanais que transmitem uma vaga noção étnica, a padronização de produtos para mercados ditos "nacionais", "globais" e assim por diante, negligenciando a diversidade cultural, "manipulando" e generalizando características e requisitos simbólicos, de uso e técnicos. Ou seja:

A Índia, por exemplo, é um país-cultura em relação à França, mas pode ser considerado um país multicultural, tal a diversidade étnica, religiosa e linguística, que se imprime no interior de seu continente. Assim, mesmo países homogêneos, do ponto de vista linguístico, étnico, religioso e institucional, apresentam diferenças internas consideráveis.

Assim, a criação de identidades nacionais para os países e a geração de identidades para corporações globais, por meio do uso 
estratégico do design posicionado ao longo das decisões políticas e de mercado, foram um fenômeno restrito ao século XX. Ambos dependiam estreitamente do conceito de criação e do papel que o design desempenha com eles.

Em diferentes momentos, o design tem estado na vanguarda cultural, e mesmo em outras formas de mudança, desde o início do século XX. Os designers têm trabalhado em conjunto, mesmo sendo inspirados por artesãos, arquitetos, políticos e tecnólogos entre outros. Eles têm sido guiados por diferentes correntes, dependendo das preocupações correntes. Se as mudanças políticas estão na ordem do dia, então esta será a direção na qual provavelmente os designers olharão. Se for substituída pela sensibilidade artística, haverá alguma reação, de algum modo. Em outras palavras, a interação entre design e cultura é essencial para que os objetos produzidos estejam em sintonia com as necessidades e os desejos das pessoas para as quais se destinam.

A cultura do design - uma "ressaca" proveniente do trabalho de designers consultores americanos pioneiros dos anos 1930 - foi substituída pela "experiência cultural", na qual designers representavam um papel ainda mais importante. Embora a cultura do design ainda preenchesse as páginas das revistas e estivesse representada nos anúncios de TV que promoviam toda a sorte de produtos e serviços, no início do século XXI seu potencial ainda está sendo usado. A linguagem da modernidade e a noção de individualismo criativo, as quais tinham sido inerentes desde o início do modernismo e ainda eram fortes oito décadas depois, relembravam um caminho poderoso para se vender coisas. Mas a cultura que representa isso tem um olhar cansado, mesmo naquelas áreas em que tal fato nunca tinha sido visto antes, como a área de automóveis. Como resultado da apropriação pelo mercado de massa retratado em organizações como a Ikea, ${ }^{2}$ talvez a mensagem de design tenha

2 Cadeia de lojas de móveis e utensílios domésticos existente em praticamente toda a Europa. A TokStok tenta ser a Ikea brasileira, só que o preço não é equivalente. Disponível em: <www.ikea.pt>. Acesso em: mar. 2007. 
sido diluída, e há um consenso de que a ideia de consumir "desejo" precisa ser revigorada de novas maneiras.

Assim, mais e mais países sofrem a experiência "real" da perda das características locais e nacionais, que vão sendo substituídas. Em seu lugar, é oferecida aos consumidores uma variedade da versão nacional de "sonho moderno", o qual é, ao final, parte do mesmo sonho que, assim como um moderno estilo de vida, é acessado por meio do consumo.

Na prática, as políticas de design, em geral, são motivadas principalmente pelos benefícios que podem trazer às empresas - lucratividade - e aos governos - vantagem econômica. A essência das políticas de design não contempla necessariamente a sustentabilidade, a não ser de forma indireta.

Pode-se, ainda, citar uma área de influência contextual de especial relevância: o modo como o design é entendido pelo público em geral, que é profundamente influenciado pelos resultados desta área. A maneira como o design é representado na mídia, o nível de discussão sobre sua importância e contribuição para a vida econômica e cultural, o pensamento das pessoas a respeito de seu papel prático, esses são alguns dos aspectos que servem de indicadores neste contexto. No entanto, as mensagens são extremamente confusas ou mesmo inexistentes. Considerando que boa parte do design do século XX foi determinada pelas percepções dos fabricantes e por suas decisões sobre o que os consumidores deveriam usar, não é de surpreender o imenso volume de dados disponível de mercado, mas há pouca compreensão com relação ao que as pessoas realmente pensam sobre design. Neste aspecto, é grande a necessidade de pesquisas que estabeleçam indicadores claros sobre como o design é compreendido.

Neste contexto atual de globalização, e com a expansão de empresas multinacionais, a relação entre design e cultura torna-se crucial. Via de regra, as empresas levam consigo um modelo de design por vezes inadequado à realidade cultural local. Essa inadequação gera frustração no momento em que os usuários não se identificam com aqueles produtos. 
Os métodos e conceitos de design que surgiram ao longo do século passado estão em constante evolução. A produção em massa está entrando em uma nova fase, estendendo-se a mercados globais com base em modelos sistêmicos bastante sofisticados. O progresso de globalização, o desenvolvimento industrial e a urbanização no denominado "Terceiro Mundo" e nos países "em desenvolvimento" ou "periféricos - onde se concentram $90 \%$ da população mundial - também fazem surgir questões prementes a respeito do papel econômico e cultural do design.

A transição que se opera atualmente no panorama internacional é baseada na busca do bem-estar e da igualdade, em oposição à eficiência; na qualidade, em oposição à quantidade; na sustentabilidade, em oposição ao desenvolvimento econômico puro; nas propostas e metodologias complexas de design, em oposição à expansão de produtos tangíveis. E neste panorama ainda não está claramente definido qual rumo o design irá tomar, mas, de acordo com Heskett (2008), as novas tecnologias, os novos mercados e as novas formas de organização comercial estão mudando significativamente o mundo em que vivemos, e obviamente novas teorias e práticas de design necessariamente irão surgir, de modo a adaptar-se aos novos determinantes.

As estruturas produtivas são cada vez mais baseadas em conhecimento, e desta forma o nível de educação interfere diretamente não só na evolução do indivíduo, mas também na produtividade das empresas e no resultado macroeconômico do país. Assim, segundo Manzini \& Velozzi (2002), o novo paradigma do design é baseado no conceito de economia criativa, em que o capital humano criativo é a base para o desenvolvimento. 



\section{3 \\ DESIGN FINLANDÊS: ANTECEDENTES HISTÓRICOS}

O princípio básico do Funcionalismo - "forma segue a função" - é o mesmo das formas definidas há séculos de acordo com as necessidades práticas de uso. Isso explica a naturalidade da funcio-

nalidade estética tanto na arquitetura como no design desenvolvido na Finlândia. A percepção do design finlandês é objeto-específico. O objeto carrega uma mensagem de cultura, mesmo além de seu meio ambiente original. O resultado é que, no ambiente cotidiano, pureza formal e funcionalidade acabaram por se tornar sinônimos de design finlandês, em uma tendência a enfatizar seu internacionalismo. Isto se tornou um paradoxo interessante, porque tais objetos tornaram-se representativos do design internacional, embora continuem a falar com um acento finlandês.

A natureza fornece o motivo místico para o discurso do design. O "sentimento finlandês para com a natureza" é, provavelmente, um mito, mas como a maioria dos mitos, é simultaneamente verdadeiro e não verdadeiro. Não é apenas uma questão de apropriação de formas, mas é também gerado por um aparentemente ingênuo naturalismo ligado ao temperamento dos finlandeses, que derivaram suas ideias na criação de objetos, texturas e cores da natureza. As formas da natureza têm inspirado a construção de uma identidade cultural e artística desde a época do Romantismo Nacional, no 
fim do século do XIX. Na Finlândia, "natural" ou "não forçado" também são palavras associadas ao Funcionalismo, cujo design ideal é honesto em relação aos materiais, limpo, com formas reconhecíveis e com contato visual com a natureza.

Sempre é dito que os finlandeses encontram inspiração no gelo, na água e nas árvores. Eu amo a natureza apaixonadamente, mas eu realmente não posso me recordar onde eu apanhei aquela gota de criatividade. Eu não me apoio numa pinha e tenho ideias disto. Eu certamente amo pinhas, depois de ter trabalhado na indústria florestal quando jovem. Eu fui embora, então, para a Karelia para pintar aquarelas, como Akseli-Gallen-Kallela e Louis Sparre fizeram. Tive a mesma orientação básica, como fizeram eles. Realmente não pode ser explicado. É moldado pelo fascínio da natureza finlandesa, o fascínio do selvagem, algo todo que se alonga da terra para cima no paraíso. (Sarpaneva, s. d., tradução nossa)

A forma "orgânico-natural" também providenciou um atalho para o formalismo avant-garde, entendido nos círculos internacionais como uma expressão estética "nacional", moderna e escultural. Ainda que abrandado pelas associações com a natureza, embrenhava como que despercebido para dentro do reino da abstração moderna e era uma referência aos elementos nacionais trabalhados para legitimar as novas formas experimentais. Isto foi verdadeiro tanto na Finlândia como em outros países. Para os finlandeses, o contexto nacional evocava sentimentos de segurança conectados com continuidade cultural e independência, enquanto fora enfatizava-se o exotismo, "um algo a mais" concedendo pontos para uma alternativa moderna.

A combinação de formas dinâmicas, inequívocas cores e texturas e a clareza dos objetivos dão ao objeto uma simplicidade própria, em que o senso de contexto é um processo de design definido em termos de forma/função, e formas funcionais são escolhidas frequentemente por seu apelo universal. O uso da madeira, material 
tradicionalmente empregado, alia funcionalidade e plasticidade. O significado dos materiais é caracterizado pelo equilíbrio entre ideia, técnica, (industrial e/ou artesanal) e material, e a indústria finlandesa responde com controle de qualidade e técnicas de produção. Da união de forças da criatividade dos artistas com a experiência da indústria surgiram soluções atrativas para os problemas de uma moderna sociedade design-consumidor (good design, good business).

As artes plásticas, assim como a literatura, são frequentemente interpretadas como expressões diretas do estado da mente de seu criador, mas isto não se aplica ao design. Entretanto, a mentalidade finlandesa, com sua ênfase na cultura coletiva ou unificada, tem, sem sombra de dúvida, deixado sua marca nos ideais conceituais e estilísticos do design finlandês moderno.

Os objetos não são variações de outros objetos ou "histórias sobre história", mas são lidos como "histórias" sobre pessoas modernas e são interpretados como produtos da realidade finlandesa, que por sua vez reflete a personalidade de seus autores. Os objetos do design moderno finlandês devem ser destacados em relação à paisagem finlandesa, pois esta tem papel como a maior fonte de criatividade.

O mais atemporal dos objetos é aquele que se sucede sempre em termos estéticos e sociais. Carrega o significado, recorda o obscurantismo da vida diária. Na realidade contemporânea da Finlândia, os significados pré-modernos dos objetos vivem certamente não somente no design moderno, mas também nos novos usos dados à forma pela vida social, ou seja, não apenas retomam sua natureza, mas tornam-se parte dela.

Por exemplo, a faca pukko (Figura 4) e seu significado como uma ferramenta historicamente conhecida como essencial para a sobrevivência no meio ambiente hostil, e a comparação com os telefones celulares da Nokia. Na Finlândia, mesmo quem não era urbanizado até a década de 1960, agora envia mensagens verbais e textuais por meio de suas "pukkos" de sua cultura contemporânea. 


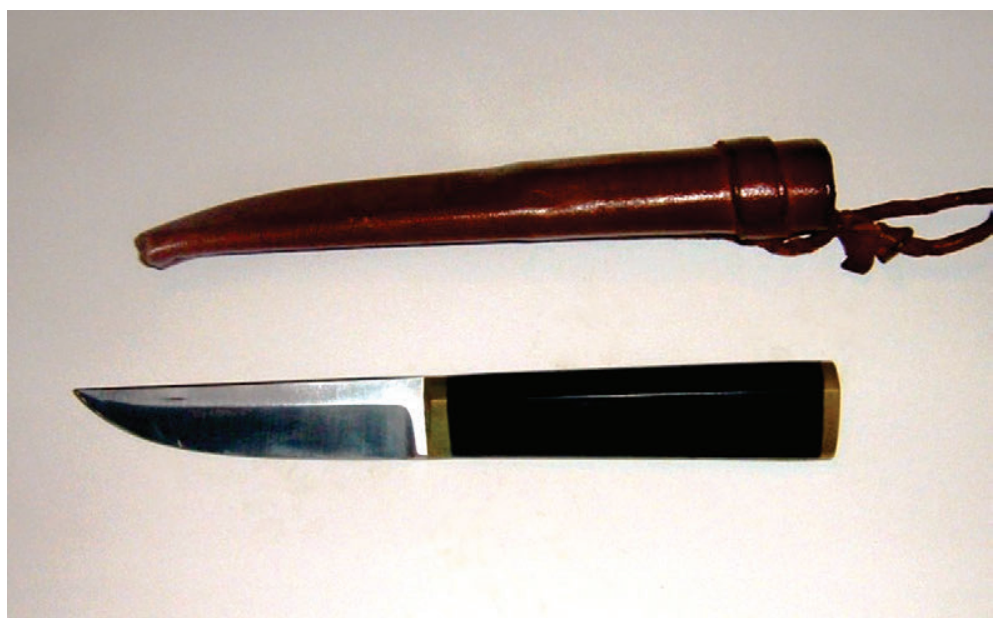

Figura 4 - Modelo da tradicional faca pukko finlandesa.

A arquitetura rural vernacular medieval da Finlândia foi uma das fontes de inspiração quando, no final do século XIX, os artistas e os arquitetos finlandeses foram motivados a redescobrir uma identidade cultural distinta. Estes "revivals nacionalistas" eram a tônica na Europa de então, mas na Finlândia foi um episódio único, gerando um revolucionário movimento artístico: o Romantismo Nacional. ${ }^{1}$ Esse revival, apesar de motivado pelos mesmos impul-

1 Todas as formas de arte foram inspiradas nos valores nacionais - por exemplo, a obra do poeta Eino Leino, do compositor Jean Sibelius, do pintor Akseli Gallen-Kallela, do escultor Emil Wikström e do arquiteto Eliel Saarinen -, sobretudo no Kalevala (épico nacional da Finlândia que consiste em uma coletânea das tradições mitológicas e cantos populares montada por Elias Lönnrot, no século XIX, em um exemplar de conteúdo basicamente do período medieval. É onde se encontra toda a narrativa mitológica da criação do mundo, dos homens e deuses, bem como a cosmologia específica das culturas balto-fineses). Essa obra, ainda hoje, é a pedra angular da arte finlandesa. O uso do Kalevala pelos artistas da atualidade não se resume apenas à transcrição dos textos ou à sua ilustração. Procura-se, sobretudo, tratar as eternas questões da humanidade - vida, morte, amor e a labuta diária - através de seu mundo místico, e, portanto, ainda desempenha um papel ativo na vida cultural finlandesa. 
sos que tinham inspirado Morris e seus associados na Inglaterra com forte influência da Red House, em Hvïtträsk ${ }^{2}$ (Figura 5), construída por Gesellius, Lindgren e Saarinen), foi também um produto da situação política e dos sentimentos envolvidos. Uma profunda necessidade de senso de identidade nacional, fortalecida pela repressão do regime de dominação da Rússia, que naquela época negava ao país seu grande grau de autonomia (o qual, teoricamente, possuía desde 1809), chegando mesmo a negar ao povo o uso de sua língua nativa. Desta maneira, eles expressaram primeiramente esse impulso em termos arquitetônicos, construindo casas no estilo tradicional. A partir de 1890, o Romantismo Nacional é reconhecido nos círculos internacionais com a construção do Pavilhão de Exibição Finlandês na Exposição Mundial de Paris, em 1900, separado do pavilhão Russo. O mesmo impulso para uma identidade nacional encontrou expressão na música de Sibelius e nas pinturas de Akseli-Gallen-Kallela, mas era mais evidente na Arquitetura e nas artes aplicadas, e não demorou para que tivesse um significado político.

Em uma perspectiva de quase duzentos anos, o importante é ver como as várias gerações têm interpretado o Kalevala, aproveitando o antigo para criar algo novo, continuando a ter um lugar importante no cerimonial e no cotidiano dos finlandeses. Disponível em: < http://www.finlandia.org.pt/doc/pt/infofin/kalevala.html\#page_top >. Acesso em: 11 set. 2008.

2 Datado entre 1901 e 1903, o edifício principal, construído de madeira e pedra, foi, durante algum tempo, estúdio e casa em comum para Eliel Saarinen e Armas Lindgren. Durante esse mesmo período, Gesellius morou na cabana construída ao lado, depois na ala norte do edifício principal, quando Lindgren mudou-se para Helsinque. Os arquitetos eram visitados por figuras importantes no cenário artístico finlandês, tais como Jean Sibilius, Axli Gallen-Kallela e Korac Gorki. Os empregados do escritório também viviam em Hvïtträsk, e foi onde os projetos para a Estação Central de Helsinque e para o Museu Nacional da Finlândia, entre outras grandes obras, foram feitos. Hvïtträsk foi também onde o famoso arquiteto Eero Saarinen passou a infância. De nacionalidade finlandesa, fez sua reputação, principalmente nos Estados Unidos, projetando edifícios e monumentos como o Gateway Arch, em St. Louis, Missouri. Disponível em: <http://www.finnguide.fi/sightguide/attractions. asp? $\mathrm{a}=2 \& \mathrm{p}=182 \& \mathrm{t}=5>$. Acesso em: 11 set. 2008. 




Figura 5 - Vista externa e vistas internas de Hvïtträsk.

O Modernismo surgiu na primeira década pós-independência, a qual aconteceu em 1917. O novo Estado precisava de novos edifícios, objetos e símbolos, tornando-se assim mais "compreensível" ao restante do mundo do que os pinheiros e ursos do Romantismo Nacional, o qual era muito alegórico. E significava também a ideia que se cristaliza no fim dos anos 1920 no discurso progressista do design sobre objetos utilitários. Particularmente após a Segunda Guerra Mundial, o Modernismo foi considerado em sintonia com os ideais da democracia ocidental e com os valores nacionais de liberdade individual, com estreita relação entre a tradição e as tendências modernas. Os conceitos contrastantes de tradicional/ 
moderno foram associados também com temas tais como clássico/ moderno, finlandês/sueco e romântico/racional.

Em 1930, com os efeitos devastadores da depressão associados a problemas de urbanização e rápida industrialização, os designers expressaram sua preocupação sobre os objetivos do funcionalismo, o significado da indústria enquanto uma força social e cultural e a mudança de uma sociedade baseada no artesanato para uma sociedade manufatureira economicamente viável. Exemplo disto foram o Pavilhão Finlandês para a Paris World Exposition, em 1937, e aquela para a New York World's Fair, em 1939, projetados por Alvar Aalto. A discussão era se deveria prevalecer o Funcionalismo (proposta de Alvar Aalto: enfatizar a produção para a massa) ou o Tradicionalismo.

A Exposição de Estocolmo, em 1930, foi um marco para o design finlandês, assim como para o design escandinavo de modo geral, é reconhecida como a introdução formal do Modernismo na Escandinávia, e ajudou a intensificar a discussão na Finlândia sobre a qualidade do design para objetos do dia a dia.

O design finlandês foi subvalorizado no contexto escandinavo e descrito como algo exótico e primitivo. Segundo a crítica sueca, o design na Finlândia era, apesar de não ter sido concebido assim conscientemente, "a cultura da forma”, de proporções calculadas, apesar de parecer resultado de um inocente jogo infantil com os materiais.

A recepção crítica do design finlandês na Escandinávia foi grandemente influenciada pela concepção finlandesa de sua própria cultura de design. A repetição da metáfora de juventude e inocência na recepção escandinava das artes aplicadas finlandesas significou uma nova e revigorante força, mas também indicou a posição da Finlândia na hierarquia nórdica.

As artes aplicadas finlandesas tinham uma relação ambivalente com os "objetos cotidianos" filosoficamente propostos pela democracia nórdica, e sua cultura em design fora longamente mantida por uma elite artística. A crucial questão sobre o papel do artesanato dentro do campo do design como um todo tem sido discutida 
na Finlândia desde a virada do século XIX para o século XX. Os conceitos de "socializar os gostos" e "mais beleza para objetos cotidianos" tornaram-se populares mesmo nos círculos finlandeses de arte aplicada.

O princípio do design como forma, função ou métodos de produção não figura nesse tipo de contextualização. O design finlandês fez sucesso internacionalmente principalmente por suas características intrínsecas: sua autenticidade, originalidade, essencialidade exótica e qualidade. E assim, por sua vez, é como os finlandeses aprenderam e aceitaram mostrar seu design internacionalmente.

A forte identidade das modernas artes aplicadas finlandesas pode ser reconhecida na tendência da crítica em estabelecer paralelos entre design e artes aplicadas, música e poesia. Essas comparações revelavam convenções em crítica de arte e design, mas eram também estratégias para a promoção do valor artístico das artes aplicadas.

Individualidade, criatividade, artesanatos, humanidade e nitidez regional, em oposição aos produtos em massa e à globalização anônima, eram os fatores por trás dos produtos da Finlândia na década de 1950. Em um mundo em transformação, a produção finlandesa ainda mantinha sua resistência e a alta qualidade de seus projetos.

Os produtos finlandeses podiam, então, ser analisados em relação aos objetos produzidos na Escola de Ulm e sua filosofia: produção de objetos de alta qualidade e para todos por meio de uma produção industrial em massa. Objetos mais bonitos para o uso diário, caminho para a cultura contemporânea em design.

O primeiro sucesso finlandês internacional pós-guerra foi na Milan Triennale, de 1951, e ajudou a incrementar a crença nos designers como parte da indústria das artes aplicadas, o que por sua vez resultou em maiores oportunidades para aqueles. Seus triunfos também transformaram os designers em heróis públicos, consideravelmente ajudados pelas vendas.

A mostra Design in Scandinavia, nos Estados Unidos, de 1954 até 1957 , foi claramente para enfatizar o sentimento de solidarieda- 
de entre os países nórdicos, o que foi importante do ponto de vista dos desentendimentos sobre a posição política da Finlândia nos Estados Unidos. Na Europa do pós-guerra, a segurança econômica era vista, particularmente pelos Estados Unidos, como essencial para a prevenção de descontentamentos sociais e políticos do tipo que poderiam levar a outra guerra. $\mathrm{O}$ design - primordialmente de objetos para a casa - tinha um papel essencial na economia para a Finlândia. Enquanto o mundo movia-se rapidamente através do que se tornou conhecido como a Guerra Fria, o design tornou-se parte de um esforço diplomático para promover o comércio finlandês, assim como a imagem da Finlândia no estrangeiro.

As décadas de 1950 e 1960 representaram o sucesso internacional do design finlandês, assim como na virada do século XIX para o século XX, quando a arquitetura finlandesa e as artes aplicadas também eram foco da atenção internacional. Em ambos os períodos, os elogios estrangeiros elevavam e aumentavam o status e a importância desses campos e de seus representantes no contexto doméstico, apesar de a imagem do sucesso pós-guerra no design da Finlândia ser principalmente associada a artefatos artesanais ou objetos feitos em pequenas séries que eram identificados como arte.

Assim como a economia nacional e o setor cultural, o design e a artes aplicadas na Finlândia durante o pós-guerra eram um arranhão em uma situação limitada pelos severos termos de paz e ressarcimentos da guerra com a então União Soviética. Mas essa situação também permitiu a realização de habilidades derivadas dos anos do pré-guerra, adaptadas das visões igualitárias implícitas no modernismo nórdico. Agora havia demanda para esses valores enquanto um desenvolvimento material e cultural que havia sido criado com recursos limitados da melhor maneira possível, apesar de a Finlândia ainda ser uma sociedade predominantemente rural.

O design finlandês nos anos 1950 não deve ser discutido apenas com referência ao brilhante sucesso na Milan Triennale em 1951, 1954 e 1957, mas também considerando como muitos lares finlandeses beneficiaram-se da desafiadora perícia do design dentro da indústria. A conexão industrial foi de prima importância, pois 
apenas por meio dela grandes grupos de consumidores domésticos puderam ser alcançados. Para esses consumidores, objetos de arte exclusivos ou de arte em vidro produzidos em pequenas séries representavam um papel secundário em suas necessidades domésticas.

A partir da década de 1950, as artes aplicadas finlandesas e o design tornaram-se internacionais em dois níveis: na esfera da exposição pública e reputação profissional, e na atual industrial baseada no design. Isto não foi uma realização insignificante do ponto de vista da modesta economia da Finlândia, geograficamente localizada à margem e com baixo nível de industrialização. $\mathrm{O}$ design também encontrou apoio em uma tendência política que soube tornar isso claro para a comunidade internacional, o que, em termos de sociedade e cultura, mostrava que a Finlândia pertencia ao "Mundo Livre". Isto conduziu à modernização rápida da comunidade de design, envolvendo os designers, suas organizações, sua promoção, sua indústria e seu marketing.

Assim como a indústria incrementou o uso de profissionais de design, o mercado doméstico, aproveitando-se dos benefícios das tarifas protecionistas, criou oportunidades para responder à demanda desencadeada pelo aumento do poder aquisitivo dos finlandeses, fazendo produtos segundo as doutrinas do Modernismo, ou ao menos adaptados aos seus princípios, especialmente em jogos de jantar e/ou chá e café de cerâmica, e várias peças de mobiliário que tinham ganhado prêmios internacionais e que agora estavam disponíveis aos consumidores da classe média. Isto não passou despercebido nos Estados Unidos e em parte da Europa, onde produtos similares estavam disponíveis apenas para a elite.

Depois da Segunda Guerra Mundial, o ensino em design passou por reformas mais completas, direcionadas mais explicitamente para a indústria. Enquanto o setor industrial crescia, diversificava-se, e os mercados e demandas cresceram durante os anos 1950. O sistema educacional preparou um crescente número de pessoas com nível e treinamento elevado para ir ao encontro dessas necessidades. O design de produto tinha, não há muito, saído do tradicional "ba- 
seado no material" educacional e na imagem profissional das artes aplicadas. Na Finlândia, isso era confirmado pela diversificação de produtos industriais e de materiais.

Entre as décadas de 1950 e 1960, um modernismo de alto padrão internacional em arquitetura e design foi estabelecido na criação e na formação do ambiente em contextos públicos e também em algum grau no contexto privado. A educação em design, a prática profissional e a indústria utilizando isso, todos eram influenciados pela rápida industrialização da nação e, de modo mais geral, pela concepção de indústria baseada no progresso tecnológico enquanto um dos principais fatores determinantes da sociedade e cultura. Na profissão de design, esses desenvolvimentos conduziam para o surgimento da indústria do design enquanto setor separado da atividade e, muito depois, da educação. Designers profissionais tinham trabalhado para a indústria desde sempre, mas baseando seus trabalhos em materiais específicos. Essa nova situação envolvia a produção em geral, o equipamento e o design ambiental, assim como o gerenciamento de uma imagem corporativa projetada.

A indústria finlandesa e suas organizações oficiais tinham grande interesse no potencial de contribuição do design para a vida industrial da nação e como um fator para melhoramento da competitividade internacional, e o desenvolvimento finlandês estava atento ao cenário internacional.

Nos anos 1950, a imagem doméstica do design foi sustentada pela reputação internacional, notadamente focada em indivíduos por meio dos quais os produtos comercializados eram associados à aura artística de famosos nomes do design.

Na década de 1960, o design industrial finlandês assumiu um grande status. A crítica ao culto da personalidade que se desenvolveu em torno dos designers individuais durante os anos 1950, combinada com uma opinião otimista no potencial da indústria, tinha afastado o interesse das artes aplicadas. Isto correspondeu a uma crise difundida nas artes aplicadas finlandesas. Com a recessão global, a indústria não podia mais fornecer emprego para todos os novos designers por muito tempo. Essas considerações figuraram 
na discussão internacional e foram debatidas, mas ofuscadas pelo foco no design individual na Finlândia, apesar da extensa discussão sobre o papel do design industrial.

Ao final da década de 1960, o campo do design industrial e do design de objetos expandiu-se para produtos em geral e para o design ambiental, que incluía, entre outras coisas, o trabalho ambiental, o tráfego e o espaço urbano. Os estudantes adotaram o conceito da responsabilidade ecológica e social para o design e suas utilizações. A forte identidade artística do design profissional, que a indústria tinha promovido, agora começava a não ser necessária como pré-requisito para a indústria, e o clima ideológico mudou.

Esse fenômeno não foi único na Finlândia. Envolveu a geração baby-boom do pós-guerra como participantes e atores, os quais questionavam as figuras que estavam no poder desde a Segunda Guerra Mundial. Por exemplo, em arquitetura, a nova geração desses anos enfatizava generalizações e pré-fabricação, obscurecendo os antigos proeminentes designers.

Apesar do debate em design, suas especificidades, responsabilidades e seu papel do designer individual terem adquirido cores radicais exageradas e terem se tornado odiados no final dos anos 1960, a comunidade de design, a indústria e os exportadores cooperavam. As aplicações industriais do design continuavam a se expandir, resultando em um crescimento das exportações nos campos e setores competentes.

A indústria finlandesa ainda tinha o ousado costume de investir em design de destaque, que em anos passados tinha provado que podia ser lucrativo. A fundamentação que tinha sido diminuída depois da Segunda Guerra Mundial e concentrado esforços em várias partes ainda tinha condições de sustentar o design tanto na Finlândia como no exterior. Durante esses anos, a Finlândia tinha se desenvolvido de uma nação predominantemente agrícola e pobre, à margem da Europa, para um Estado bem industrializado, com um alto padrão de vida e com atividade internacional. Dentro desse contexto periférico de desenvolvimento, as oportunidades de 
design tinham sido aplicadas tangencialmente ao benefício do design profissional e industrial e, indiretamente, para o bem da nação como um todo.

Na Finlândia, assim como em outras partes do mundo, os anos 1960 foram um período excitante sob vários aspectos. Diversão e fantasia eram expressos por meio de variados canais estéticos. $\mathrm{O}$ design na Finlândia era, talvez, um pouco mais contido em razão de sua tradição artesanal de uma sociedade agrícola em que os objetos eram feitos para serem usados e a decoração era considerada supérflua. Mas a pureza da forma, da clareza e da funcionalidade inerente a suas tradições sustentou os designers em uma boa posição.

A década de 1960 viu o nascimento de sub-organizações dentro da Ornamo, a Associação Finlandesa de Designers. Novas associações foram estabelecidas para designers de moda (1965) e designers industriais (1966), que se juntaram às associações já existentes para arquitetos de interiores (1949) e designers têxteis (1956). A Ornamo, agora uma associação central de designers, começou a receber anualmente suporte financeiro do Ministério da Educação para cobrir as despesas de expansão de suas atividades.

Outra característica do design finlandês em geral, e particularmente nos anos 1960, era a extraordinária versatilidade dos designers. Muitos eram capazes de lidar com diferentes materiais, ser artesãos e designers industriais, mover-se livremente de um campo do design para outro.

No final da década, o espírito revolucionário do resto da Europa afetou a Finlândia. Havia uma efervescência na School of Industrial Arts. ${ }^{3}$ Depois do Congresso de Design, em 1968, os princípios do design foram criticados pela primeira vez. O culto ao designer individual foi considerado inapropriado, e o design anônimo era a nova senha.

A década de 1970 vê surgir o interesse pela ergonomia e a ênfase social como sinônimo de bom design, semiótica (em função da crise

3 Escola de Artes Industriais, em uma tradução livre. No caso, a University of Art and Design Helsinki. 
do Funcionalismo) e valores simbólicos, e gradualmente tornou-se um período para experimentação, pesquisa e aperfeiçoamento, baseando-se no que havia se iniciado nos anos 1960. Os anos 1970 podem ser caracterizados como um período de transição, um período de autocrítica com debates frequentes.

A consciência social da população em geral, incluindo os designers, estava exacerbada na década de 1970, agravada pela crise do petróleo na primeira parte da década, e mais importância estava sendo dada aos fatores humanos. O design ergonômico estava na moda, e a recessão na indústria em geral contribuiu para a tentativa de desenvolver novos designs ecológicos, para o bem do meio ambiente e de países com recursos limitados, como a Finlândia.

A década foi ajustada para a produção em massa, mesmo a Finlândia sendo um país jovem em termos industriais e sendo as peças únicas consideradas apenas para uma elite e para exibições. Por exemplo, no departamento de cerâmica da Universidade de Artes Industriais, os alunos eram formados para desenvolver suas pequenas, mas independentes, produções. Eles produziam objetos cerâmicos parte artesanal e parte industrial, mas logo perceberam que era impossível competir com a indústria convencional, e muitos começaram a fazer peças únicas, mais artísticas e menos funcionais (Figura 6).

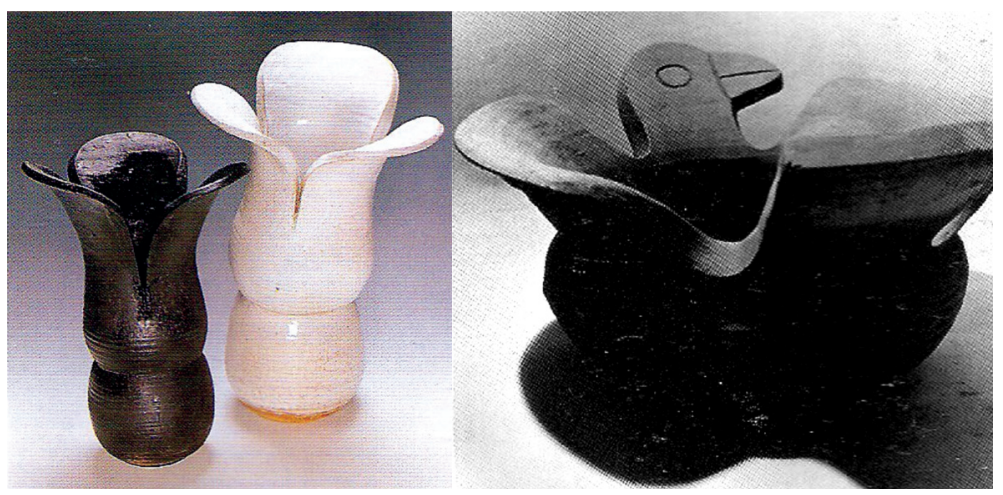

Figura 6 - Exemplo da cerâmica-arte da década de 1970. 
Os anos 1970 introduziram um estilo mais casual e com ênfase no conforto e na ergonomia no design de vestuário. $\mathrm{O}$ mundo fashion não era fashion. A popularização do jeans e a ideia de igualdade significavam que todos deveriam parecer-se. Parecia haver uma aparente contradição entre o culto ao indivíduo e a quase total uniformidade de aparência. Pela primeira vez o design e a manufatura de roupas para o trabalho e uniformes tornaram-se parte da indústria (Figura 7).
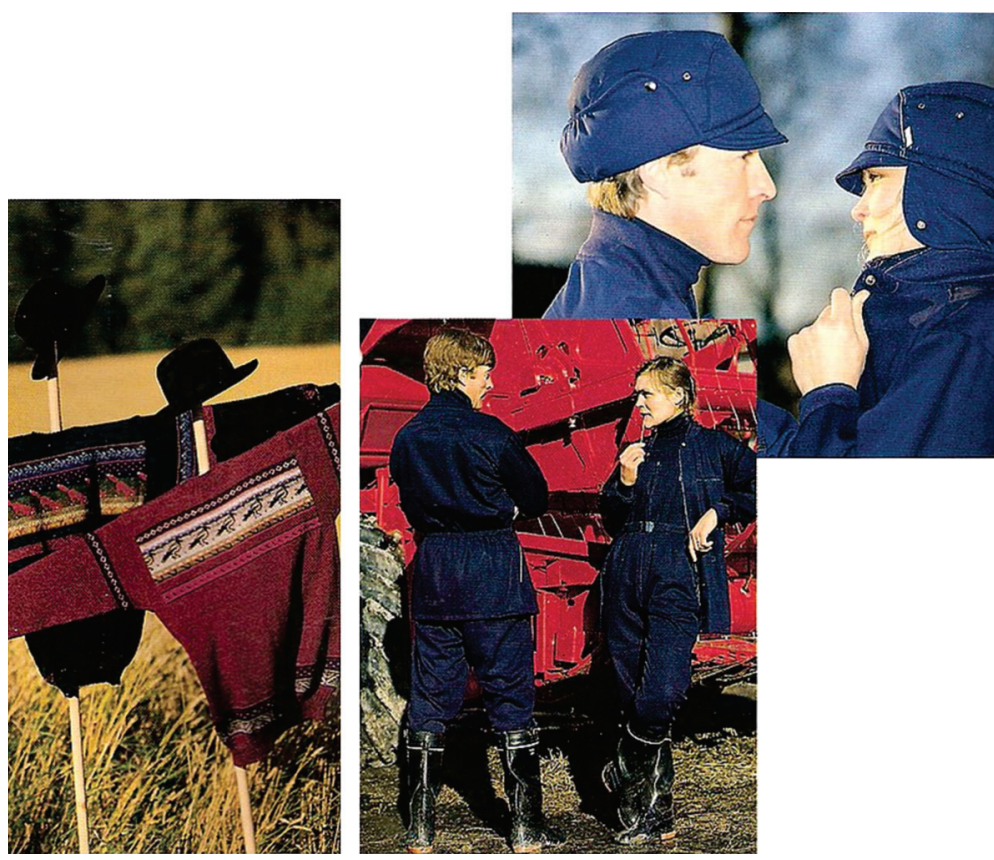

Figura 7 - Exemplos de indústria de vestuário da década de 1970.

O design de mobiliário era baseado nos princípios do funcionalismo e ergonômicos. Considerações ecológicas tendiam para a minimização de materiais e cores. O design era um processo lógico e científico, baseado na pesquisa. $O$ período pode ser classificado 
como "design for need", 4 quando as peças eram feitas para interiores institucionais, transporte e espaço público, e o indivíduo foi esquecido (Figura 8).

A profissão de designer de modo geral foi estimulada quando a School for Industrial Arts ${ }^{5}$ foi elevada à categoria de universidade, em 1973. Internacionalmente, a reputação do design finlandês continuava baseada na pureza formal, "uma brisa vinda do Norte".
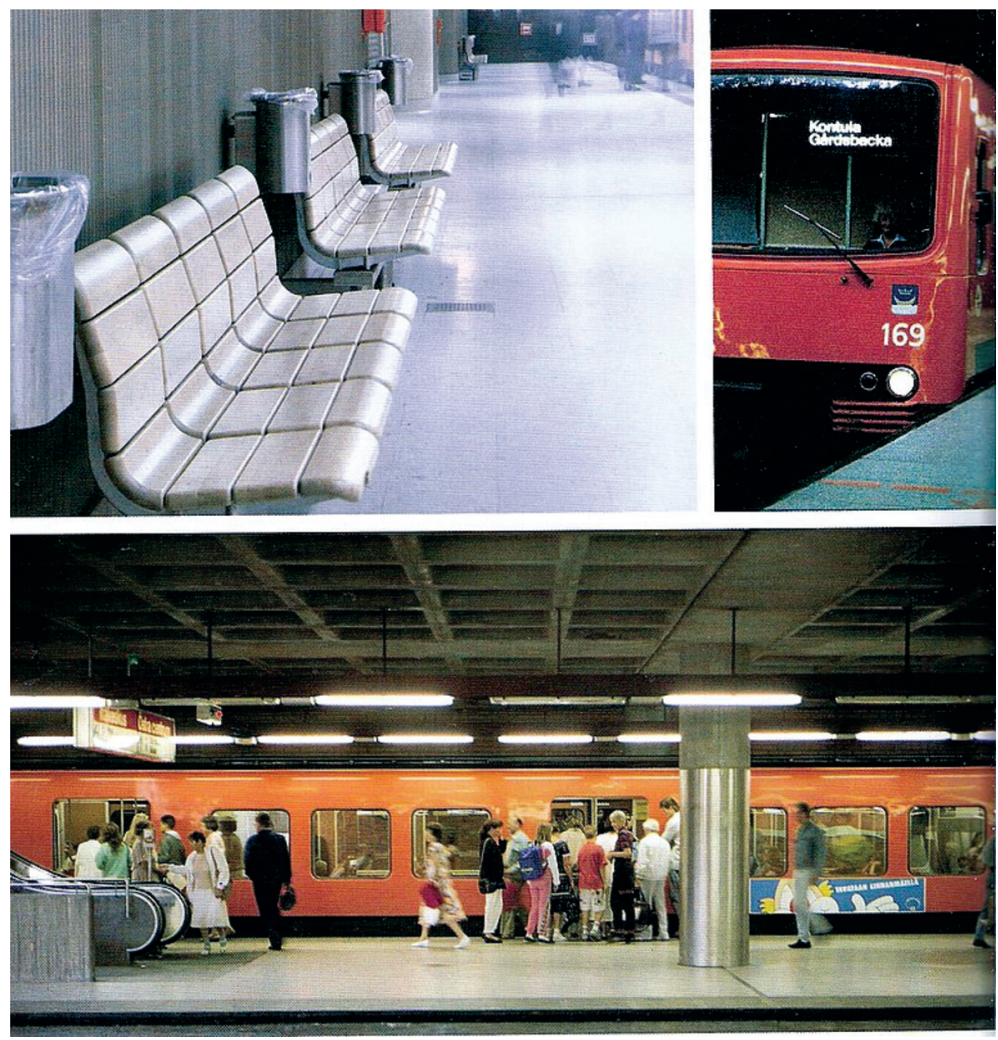

Figura 8 - Metrô de Helsinque.

4 "Design para necessidade", em uma tradução livre.

5 Escola de Artes Industriais, em uma tradução livre. No caso, a University of Art and Design Helsinki. 
A partir de 1980, o design tornou-se mais pluralista e, sob alguns aspectos, iniciou uma relação com as "artes puras", inclusive a poesia, em uma abordagem semântica, free design e/ou experimental design, e as preocupações com a ecologia e com projetos de restauração, tanto em termos de arquitetura como nas tradições do design, afetaram a percepção geral do design.

Os anos 1980 foram uma década de maturidade em design na Finlândia. Quando ergonomia e meio-ambiente tornaram-se um assunto óbvio, designers transformaram o princípio de "a forma segue a função" em "a forma segue a função e a fantasia”.

Na primeira metade da década, os designers foram influenciados pelo Pós-Modernismo, e sua liberdade e fantasia refletiram no design de mobiliário finlandês (Figura 9). Várias peças experimentais foram feitas para exibições, e ao final da década, pequenas e recém-fundadas firmas apresentavam ideias com um caráter inovador, para serem usadas em interiores tanto institucionais como privados.
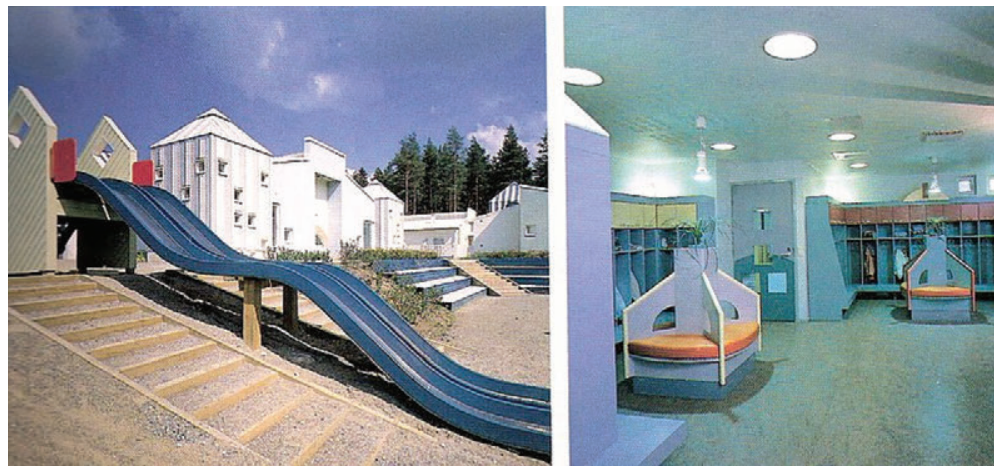

Figura 9 - Influência pós-moderna no mobiliário finlandês.

Outra característica foi a reedição de obras de designers modernos consagrados, como Eliel Saarinen (Figura 10). 


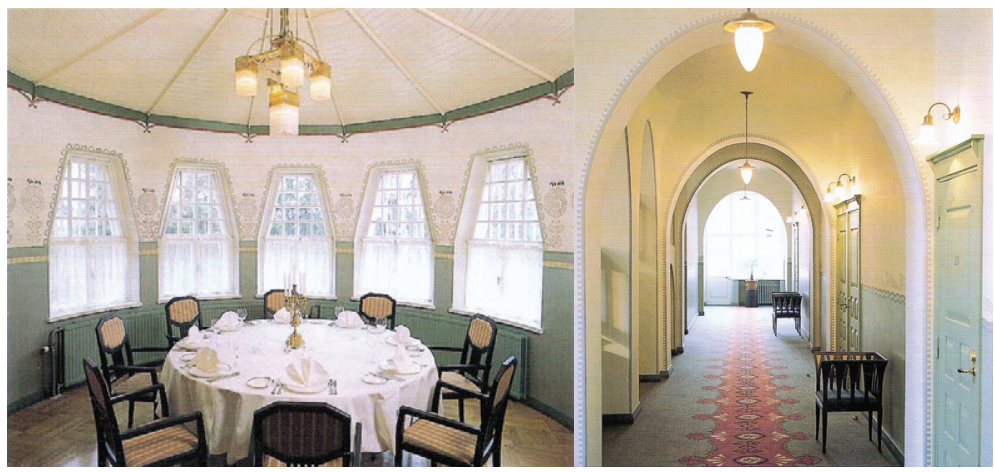

Figura 10 - Reedição de obras de Eliel Saarinen.

O design de roupas esportivas teve sua melhor década e teve vários projetos experimentais em novos materiais. As formas eram sofisticadas, e as peças de vestuário não eram cópias de marcas da moda, e sim criadas com sua própria expressão de moda (Figura 11).
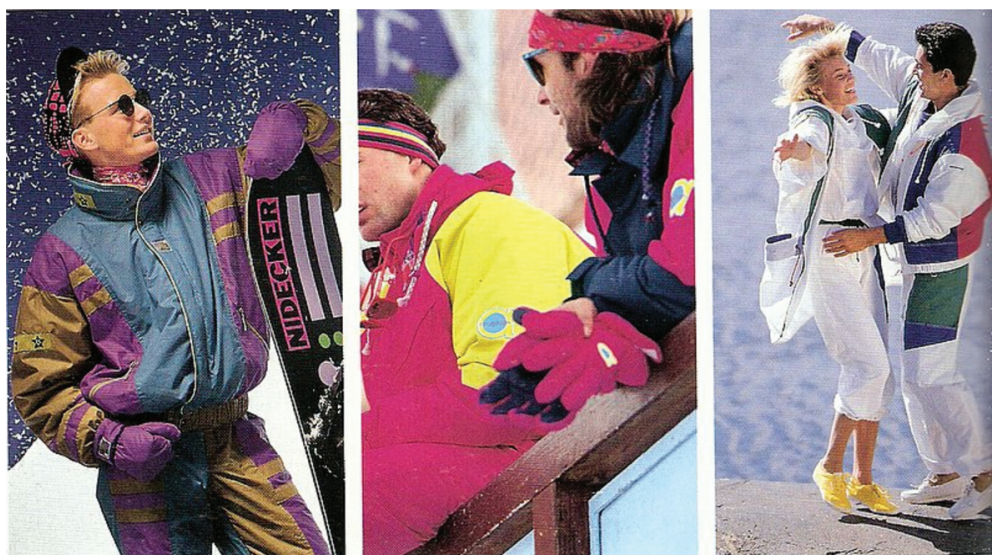

Figura 11 - Design de roupas esportivas.

A ergonomia era um elemento importante do design, assim como as considerações estéticas. Até então se prestava mais atenção aos aspectos estéticos de uma cadeira ou de um vaso do que à aparência 
de uma ferramenta, por exemplo. O desenvolvimento da estética do design industrial para ferramentas, nos anos 1980, avançou consideravelmente e tinha nível internacional. O conforto e a aparência de um trator recebiam a mesma atenção que os de um carro (Figura 12).

Em outros países existia uma separação clara entre design industrial e artes decorativas, mas, na Finlândia, artesãos e designers industriais estavam sob a mesma associação até 1983, quando

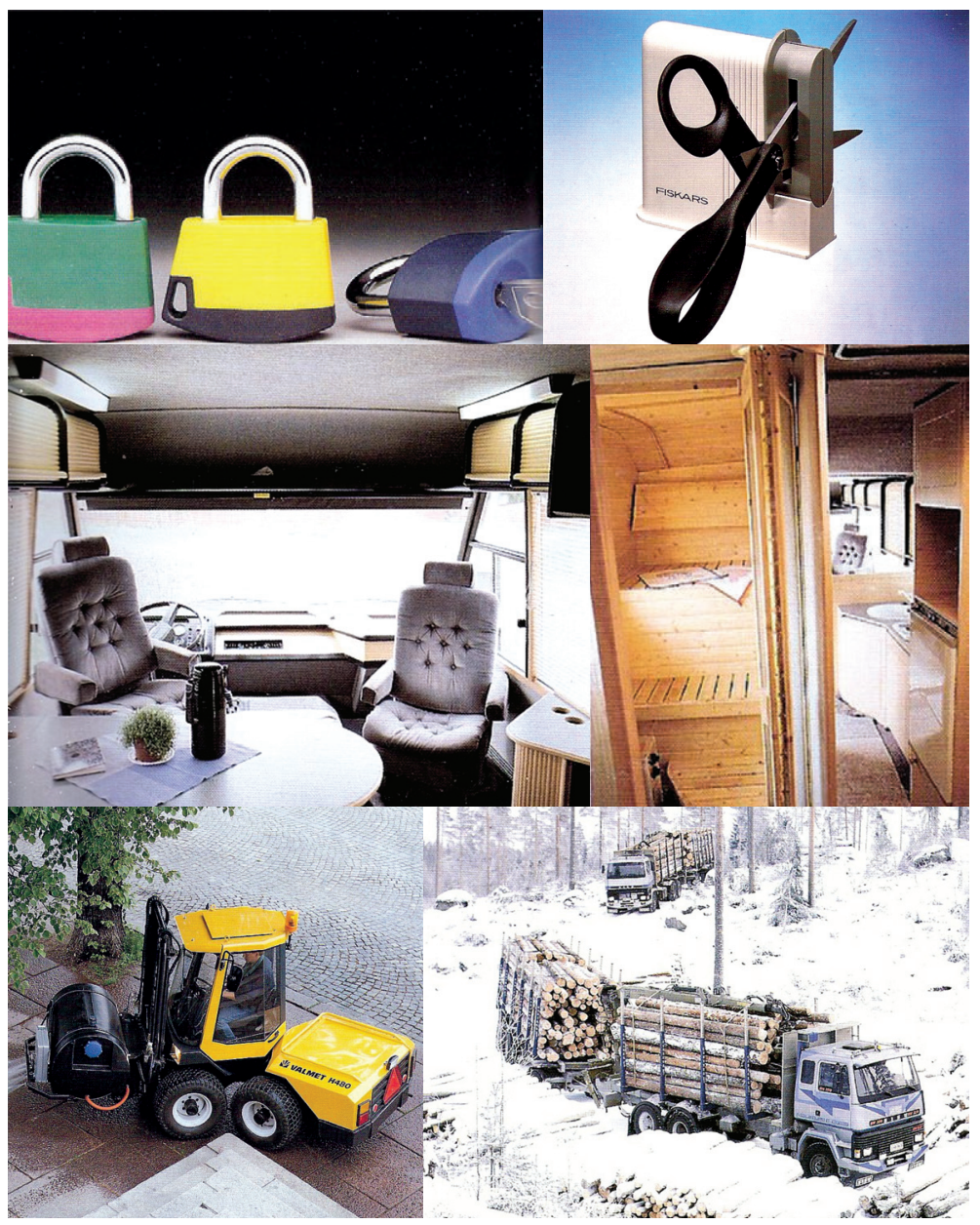

Figura 12 - Exemplo da estética industrial para os mais diversos produtos. 
foi fundada uma associação específica para os artesãos. $\mathrm{O}$ design tornou-se, então, mais especializado nos anos 1980.

A conferência da Icsid, a principal associação mundial de design, aconteceu em Helsinque, em 1981, e ajudou a comunicar a mensagem dos designers finlandeses ao mundo. O design finlandês em geral chegou à maturidade nos anos 1980 .

No design contemporâneo, esses ideais promoveram uma interpretação diferente, adaptando técnicas e materiais novos aos temas tradicionais do projeto. Naturalismo, linhas retas, minimalismo, elegância e acabamento cuidadoso continuam a serem expressos na produção atual. Mudanças tecnológicas consideráveis ocorreram entre 1980 e 1990, com influência no design, tanto em termos de produção como em novos objetos, principalmente com os novos produtos eletrônicos e o uso de computadores na concepção projetual. Aconteceu em outros países, mas não com a magnitude que aconteceu na Finlândia, a preocupação com a racionalização da matériaprima e a ecologia, presente desde os anos 1930 devido às limitações do clima. Madeira e metal são utilizados até hoje na vida cotidiana.

É evidente no design finlandês contemporâneo o produto em um contexto cultural e histórico, o Modernismo revisitado. Novas interpretações do Modernismo, em um contexto social que seja mais amplo do que um contexto real do uso. Os produtos de design podem ser interpretados como representações da cultura finlandesa e, desse modo, ligados a suas raízes históricas e aos vários pontos de vista sociais.

\section{Vidro}

As principais fábricas, iittala ${ }^{6}$ (vidro) e $\operatorname{Arábia}^{7}$ (cerâmica), são mais antigas que o discurso moderno-funcionalista. Existem desde meados do século XIX e estavam abertas a novas possibilidades.

6 Disponível em: <http://www.iittalagroup.com/web/iittalagroupwww.nsf/ pages/AFC99AC242564B2FC22571E600458792>. Acesso em: mar. 2007.

7 Disponível em: <http://www.arabia.fi/web/arabiawww.nsf/pages/E0BEF2D BAAC88F9FC2256C07002DF996!OpenDocument>. Acesso em: mar. 2007. 
A modernização da produção não necessariamente requereu algum esforço por parte dos designers. A indústria de vidro produzia simples artigos utilitários, fáceis de eliminar da produção decorativa com itens que eram formalmente complexos e requeriam acabamentos sofisticados. Criaram, então, uma coleção que era "moderna" e "funcional".

A produção era voltada principalmente para a exportação, mas apesar de exemplos de projetos intencionais para a produção em massa poderem ser encontrados em meio à produção em vidro finlandesa dos anos 1930, a vasta maioria dos projetos desse período era para objetos de arte caros e sem nenhuma intenção de serem produzidos em larga escala.

A linha "i”, da iittala (Figura 13), tentou preencher o vazio entre a arte em vidro e os objetos utilitários, e foi considerada como de "qualidade fina" para peças domésticas do dia a dia.
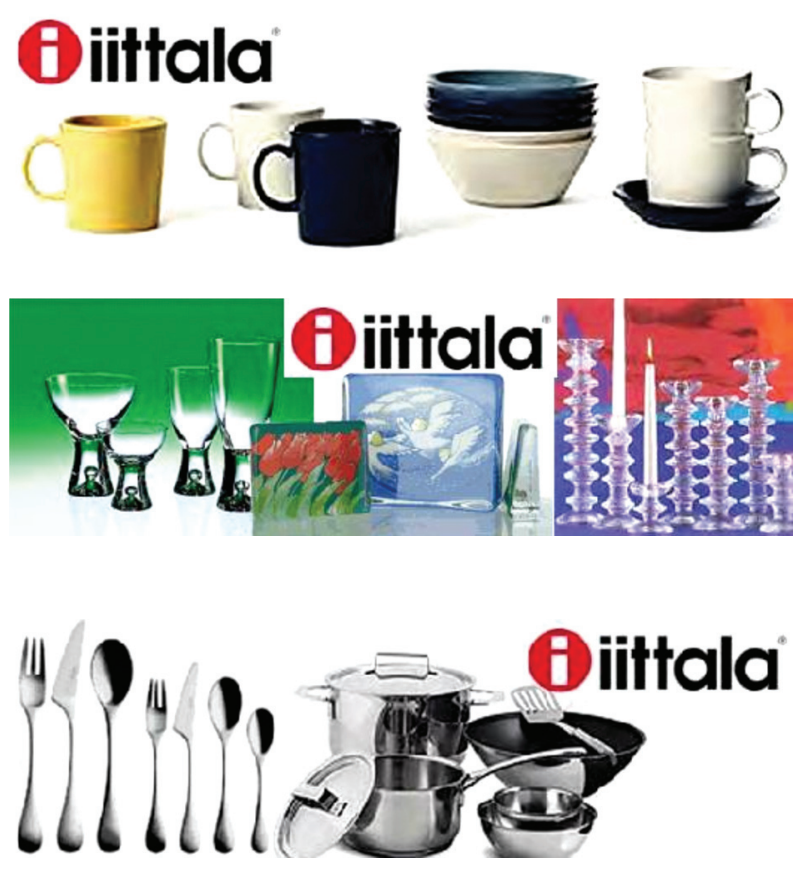

Figura 13 - Linha "i”, da iittala. 


\section{Joalheria e trabalhos em metal}

A joalheria moderna finlandesa, tanto a em ouro e prata quanto aquela com trabalhos em metal, tem uma característica em comum: a simplicidade.

Além de uma moderna representação dos ornamentos ancestrais, ela tem outra importante característica: seu desenvolvimento recente. Setenta anos atrás, os primeiros sinais do atual e impressionante florescimento não eram nem aparentes. No começo dos anos 1930, a demanda por um vocabulário de design original e nacional passou a ser sentida no campo dos trabalhos em metal.

Os trabalhos em metal finlandeses tornaram-se "respeitáveis" quase da noite para o dia. Essa mudança foi aparente tanto no revival das produções pequenas e de alta qualidade como na nova colaboração entre indústria e designers. Os consumidores tinham acesso aos aperfeiçoamentos em joalheria e em objetos domésticos cotidianos.

Até a metade do século XX, trabalhos em ouro tinham um papel bastante marginal no desenvolvimento do Modernismo. Esse atraso explica apenas em parte o gosto fora de moda de seus clientes. Em adição ao persistente conservadorismo do gosto do consumidor, outra razão para a duração da popularidade dos modelos tradicionais é a formação dos ourives. No final do século XX, apesar das novas técnicas apreendidas das outras artes aplicadas, não existia ainda o ensino formal para trabalhos com metais preciosos. Críticos e designers, os quais abraçaram o Funcionalismo em outras áreas das artes aplicadas, tinham dificuldades sobre como se sentiam em relação às abordagens modernas para a prata.

Em 1935, com o centenário da publicação de Kalevala, o épico finlandês, surgiram réplicas e variações de joias da joalheria da Idade do Ferro e Bronze finlandesa dentro do espírito de nacionalismo (Figura 14). Em 1947, surgiu uma competição para encorajar novos designers e o design inovador. Talvez o resultado mais importante da competição tenha sido incitar a colaboração entre os jovens designers e a indústria, mas foi apenas em meados dos anos 
1950 que novos trabalhos em metal e joalheria receberam a atenção que os vidros e cerâmicas finlandesas recebiam e que os produtos têxteis tinham aproveitado desde o começo da década. Os críticos aplaudiam seus esforços e reclamavam a eles igualdade aos outros campos no design moderno finlandês.

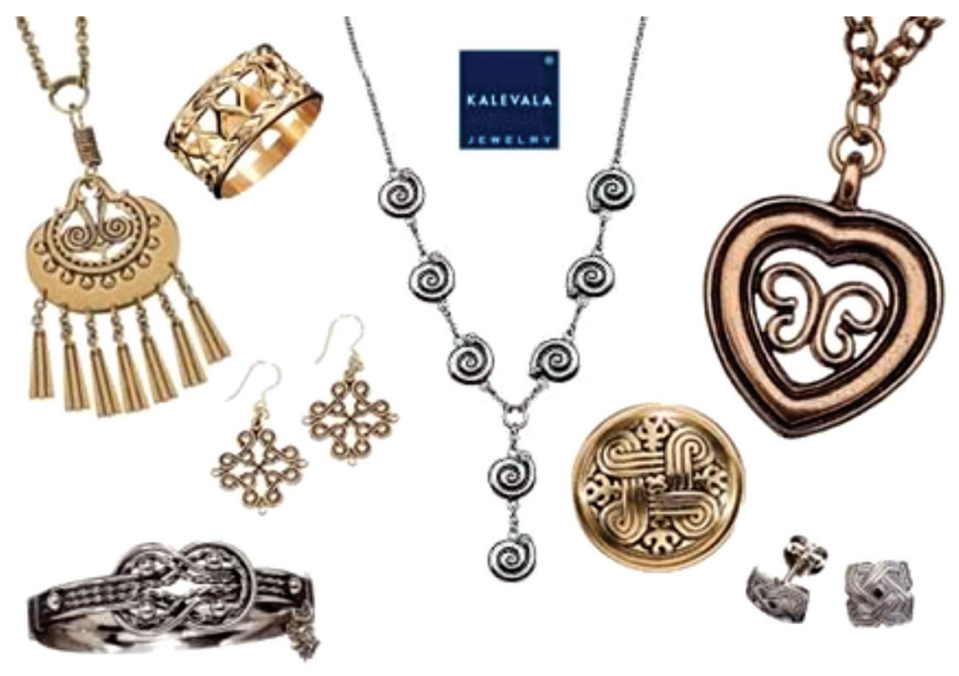

Figura 14 - Exemplo de joalheria Kalevala.

Como forma de ser aceita completamente, a joalheria teve de demonstrar mais do que nova estética. Foi apenas com a combinação de materiais locais que uma joalheria distintamente finlandesa foi criada. Até então, ela orgulhosamente exibia aos vizinhos suas joias funcionalistas com gemas estrangeiras, mas agora ela mostrava seus próprios designs finlandeses, confeccionados com ouro finlandês e decorados com gemas finlandesas. E ela tinha mesmo razão para estar orgulhosa pela linha pura, simplicidade e beleza estilística dessas joias.

Em meados da década de 1980, havia um importante novo desenvolvimento no design de joias, estimulado pelo uso de novos materiais antes desconhecidos dos joalheiros finlandeses e com 
uma nova abordagem conceitual. Entretanto, o campo, de modo geral, mantinha a mesma estética baseada nos materiais que caracterizaram a joalheria finlandesa desde os anos 1950.

\section{Produtos têxteis}

O design moderno não é uma entidade unificada na Finlândia, apesar das várias manifestações existentes. Por exemplo, nas artes têxteis, a tradição e o progresso na arte e na indústria têm existido lado a lado, e parece que continuará sendo assim. A indústria têxtil tem uma tradição relativamente longa na Finlândia, desde o século XVIII, mas como tradição folclórica, embora a relação entre o design têxtil e a produção em série esteja mais centrada nas modernas artes aplicadas. Os produtos têxteis modernos finlandeses podem ser considerados em três áreas específicas: design para indústria, com a intenção de atender uma grande audiência; produção artesanal, que incorporara a produção serial manual; e arte, com atrativos para um pequeno grupo de elite.

A arte ryijy deve ser entendida como parte de um passado prestigiado que une isso com a tradição finlandesa e com as artes aplicadas modernas do começo do século XX. Os primeiros designers têxteis eram inspirados pelas cópias de antigas peças têxteis étnicas finlandesas adaptadas ao uso em interiores de residências do final do século XIX.

Durante os anos 1920 e 1930, os têxteis tornaram-se um campo atrativo como conexão entre designers e indústria, reforçando a noção de que a arte aplicada moderna podia existir, transformando-se na chave para o discurso do design e dos designers modernos, assim como a união da arte e da indústria. Ao mesmo tempo em que a relação com a indústria estava sendo discutida, houve o "renascimento" das tradições folclóricas, que teve um amplo impacto na sociedade e cultura finlandesas. A cooperação entre artistas de indústria começou a ser objeto de discussão nos círculos da arte aplicada, e depois da Segunda Guerra Mundial, as escolas conecta- 
das com negócios e indústria expandiram-se novamente, embora os estudantes da arte têxtil por si só tivessem pouco contato com a indústria. Projetar para a indústria têxtil não era visto como uma possibilidade real, e os parceiros têxteis ainda estavam projetando principalmente para a produção artesanal como única forma de trabalho em arte têxtil. Entretanto, no começo dos anos 1950, a arte ryijy alcançou posição importante no design finlandês moderno, e no final dos anos 1960, começo dos 1970, alguns artistas renovaram a tradição fazendo relevos tridimensionais em ryijy, experimentando novos materiais e novas texturas em formas escultóricas, abrindo canais para uma nova e criativa expressão (Figura 15).


Figura 15 - Arte ryijy tradicional (a). Tapeçaria ryijy em relevo (b).

O quadro unilateral da arte têxtil como uma parte do design moderno - como o design de objetos para a indústria ou para produções artesanais - ignora a forte ligação entre a arte têxtil e a tradição folclórica. A arte têxtil é, de um jeito especial, associada a uma supra-histórica tradição de artesanato folclórico.

As primeiras tentativas, na Finlândia, para entender os têxteis como um tipo de arte independente comparável às belas-artes ocorreu durante os anos 1960 e o início dos anos 1970, com a elevação internacional de arte têxtil. 




Figura 16 - O espírito mágico dos anos 1960 também foi capturado no design têxtil da Marimekko.

Apesar das artes têxteis terem se desenvolvido rapidamente e atingindo reconhecimento público considerável - principalmente quando elas se tornam parte do sistema de apoio financeiro estatal para as artes aplicadas -, elas são discriminadas até os dias atuais por serem uma atividade eminentemente feminina, apesar de sua versatilidade, e, assim como cerâmica, ainda é vista como arte e não como design. 
O assunto da modernidade em têxteis é complexo e difícil de ser definido. Quando a história da arte têxtil finlandesa é revista em relação aos ideais da arte e do design modernos, é necessário que se reconheça que a arte têxtil "livre" ainda existe. Os artistas têxteis não se tornaram designers e a arte têxtil não foi fundida com as belas artes. $\mathrm{O}$ artista têxtil finlandês tem múltiplas identidades: design industrial, artesão e artista.

\section{Cerâmica}

A cerâmica finlandesa do século XIX pode ser explicada por meio da relação entre a fábrica Arabia e a Uiah (Universidade de Arte e Design de Helsinque). É difícil imaginar como o campo pode desenvolver-se sem essa inicial e consistente exposição ao modernismo mediante essas duas instituições dominantes.

Até o final do século XIX, os artesãos eram "meros pintores decorativos". Na fábrica eram desenvolvidas tanto esculturas em cerâmica como objetos cotidianos. A introdução do Modernismo na cerâmica ocorreu no final da década de 1890.

A cooperação entre a Central School of Industrial Arts e a Arabia existe desde a década de 1920, mas até então a arte em cerâmica na Arabia significava objetos decorativos com aparência de gosto burgueses: estatuetas, caixas, queimadores de incenso, luminárias e máscaras exóticas no "estilo" Arte Moderna. Em raras oportunidades os artistas podiam ajudar a projetar um objeto para o uso cotidiano ou um aparelho de jantar. Geralmente isso era feito por uma comissão especial. Entretanto, o ecletismo estilístico que se desenvolveu durante os anos 1920 sinalizou a procura por uma identidade artística da fábrica em expansão.

Durante a década de 1930, os ceramistas na Arabia tornaram-se mais e mais atentos ao exemplo em que eles estavam se transformando como promotores do ideal de modernidade em cerâmica, e logo a política mudou com a introdução de uma nova abordagem para a cerâmica moderna, Como resultante, em meados da década 
de 1940, passou a haver um encorajamento da livre expressão do artista, exemplificado na abertura, em 1944, no $9^{\circ}$ andar do prédio da fábrica, o Departamento de Arte e Museu.

No final dos anos 1940, o design crítico questionava a baixa (em termos de projeto de objeto, não do material em si) qualidade da cerâmica utilizada nos objetos cotidianos na Finlândia e a exclusiva e elitista natureza da cerâmica artística finlandesa. Mas o ensino (treino) em instituições educacionais privava os estudantes de um foco em objetos de uso cotidiano.

Isso tinha implicações positivas para os artistas e industrialistas. A noção de um museu evocava status e prestígio cultural do tipo que foi calorosamente bem-vindo pela jovem fábrica, e por seus artistas em particular, que com esses estúdios espaçosos, teve no $9^{\circ}$ andar a evolução para um oásis de livre criatividade. Como resultado, em 1950 ocorreu uma exposição particular da Arabia em Milão.

O departamento de arte da Arabia era um empregador ideal, com capacidade técnica e organização em marketing, e todos os ceramistas sonhavam em trabalhar lá. Era difícil construir uma carreira em cerâmica fora da Arabia, em um campo em que os métodos de produção complexos e uma boa capacidade de marketing fixaram os limites do padrão de trabalho e afiançaram a imagem pública do artista. Graças à Arabia a indústria cerâmica paradoxalmente tornou-se a principal fonte de apoio para os studios de cerâmica, fábrica essa que se institucionalizou e se transformou em uma ferramenta de marketing simbólica desses mesmos studios, um modelo que funcionou bem durante aproximadamente trinta anos.

Apesar das críticas feitas à produção da Arabia depois da guerra, o esforço em criar objetos cotidianos para produção em massa não teve resultados positivos. Um exemplo era um jogo de jantar que era produzido intencionalmente para habitações rurais. Era produzido pela Arabia em colaboração com a Finnish Population and Family Welfare Federation, uma agência governamental que melhorava residências rurais padrão. As formas, selecionadas dessa parceria, que já estavam em produção, foram decoradas com motivos florais populares. 
A série "Kilta" (Figura 17) tornou-se um símbolo do ressurgimento do design finlandês durante a reconstrução do pós-guerra. Com um preço razoável e versátil e enquanto proposta múltipla para jogo de jantar, disponível em diferentes acabamentos, a série "Kilta" oferecia ao consumidor grande flexibilidade e a oportunidade de combinar as peças de acordo com suas necessidades e gostos individuais.



Figura 17 - Exemplo da série "Kilta".

O sucesso do departamento de arte da Arabia, o qual servia de cartão de visitas da fábrica em exposições internacionais, encorajou a companhia a manter a clara divisão entre a produção de bens de consumo em massa e o departamento de arte de peças únicas.

Nos anos 1960, o currículo em cerâmica no Institute of Industrial Arts mudou dramaticamente, enquanto se acirrava o debate sobre encontrar (identificar) as necessidades da indústria. Também na produção a situação mudou. A competição internacional e a ênfase maior em um marketing comercial eficiente mais do que em aspirações estéticas minaram os ideais que tinham caracterizado o aclamando departamento de arte nos primeiros anos da Arabia. Com o apoio de uma política mais comercial e o interesse em padronizar a produção e os procedimentos de marketing, os jovens designers não 
mais consideravam a Arabia um paraíso para os artistas cerâmicos. O termo "moderno", o qual tinha previamente se associado com integridade estética e cultural, começou a significar industrialização banal. Com a crise da energia, seguida pela recessão internacional, a cerâmica finlandesa enfrentou uma crise profunda. Muitos produtos foram descontinuados. A fábrica parou de usar a tradicional tecnologia copper printing, E o design moderno era agora reduzido a uma estratégia de marketing.

\section{Mobiliário finlandês moderno}

A história do design do século XX na Finlândia - especialmente desde a década de 1930 - é apenas uma parte da história do Modernismo, assim como o mobiliário e o design de interiores são apenas um aspecto desse fenômeno. Para melhor entender essa questão, é primeiramente necessário entender qual é o papel específico do mobiliário e do design de interiores no campo das artes aplicadas em relação à arquitetura finlandesa. Em termos gerais, a arquitetura finlandesa incorporou o Modernismo internacional desenvolvido pela Bauhaus e introduzido por Le Corbusier na década de 1920. E desde o mobiliário desenvolvido por Alvar Aalto para suas construções, o ideal modernista vem influenciando igualmente o design de mobiliário.

O melhor nos primeiros funcionalistas era a habilidade de não apenas ter um repertório de ideias consistente sobre funcionalidade e praticidade do mobiliário, mas também saber usá-lo para projetar uma bela mobília.

O mobiliário de Alvar Aalto marca o início de um período em que o móvel é encarado como um objeto próprio das artes aplicadas, e mais tarde produto de um design. Ou seja, é a partir daí que começa a ser manufaturado em série pelas artes aplicadas para a residência moderna e uso em geral, pois anteriormente era parte do design de interiores, geralmente feito para uso único e individual. 
Alvar Aalto humanizou a relação do Funcionalismo com a natureza e transformou as estruturas e soluções estéticas do mobiliário. A técnica de laminação por ele desenvolvida possibilitou a produção de peças em conformidade com a estética internacional do Modernismo. Essa inovação importante no design do mobiliário moderno tornou possível combinar a matéria-prima e os métodos de produção finlandeses com a estética e o design internacionalmente reconhecidos. O mobiliário moderno finlandês surgiu então da manufatura seriada dos móveis projetados por ele, feitos com madeira prensada. Suas linhas minimalistas têm sido um dos pontos básicos iniciais da indústria de mobiliário moderno finlandês desde 1930 até os dias de hoje (figuras 18 e 19).

A Finlândia, no período entre as duas guerras mundiais, era um país essencialmente agrário, sem possibilidade de gerar uma urbanização resultante de uma classe média cosmopolita e com recursos, ou seja, de gerar um mercado em potencial para o design moderno. A carpintaria tradicional coexistia com a tendência emergente de processar a madeira industrialmente para a construção civil e para a fabricação de mobiliário. A madeira e seus derivados constituíam-se na maior riqueza do país, tanto em termos de construção civil como de fabricação de objetos, e a produção de mobiliário foi caracterizada por esses modelos históricos vernaculares. Em geral, a mobília modernista era exceção nas casas finlandesas, e o é até hoje, apesar de, ironicamente, o design de mobiliário estar mais ligado ao Modernismo do que a cerâmica, por exemplo.

Os pré-requisitos da modernidade frente à produção seriada correram paralelos ao crescente desenvolvimento de uma indústria baseada em um material barato e de aplicação direta como a madeira. Pode-se dizer que, desde o final da década de 1930, a modernização geral das tendências do consumidor, o nível tecnológico alcançado pela indústria da madeira e a melhora dos métodos de produção e distribuição haviam servido de base para o advento da modernidade na Finlândia.

Enquanto o Modernismo internacional no período entre as guerras mundiais estava expresso na arquitetura e no design de 


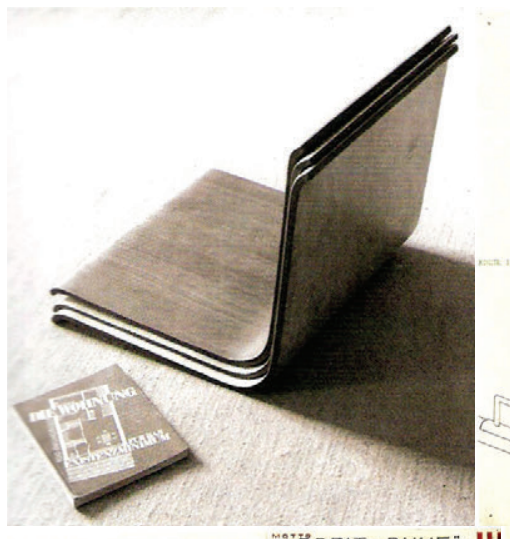

. IOSTÜCK - ๆCM." IV:

"ẢR̈BEIT - RUHE" III


CGHONA


:1):

Figura 18 - Exemplos da produção de Alvar Aalto. 




Figura 19 - Museu Alvar Aalto, em Jyväskylä, Finlândia.

interiores, após a guerra tornou-se mais ligado aos eventos cotidianos. Agora era possível entender o ideal social do Modernismo nórdico. As regulamentações governamentais para a construção de moradias, por exemplo, seguiam os princípios de saúde, de função e de higiene desenvolvidos por arquitetos e designers na década de 1930. A modernização (geralmente padrão) das cozinhas em apartamentos pequenos introduziu o modernismo no ambiente cotidiano em dois níveis: enquanto manifesto ideológico e como uma estética funcional que rapidamente se tornou comum. Em termos de projetos individuais de mobiliário, a manufatura tinha de levar em consideração a necessidade de se fazer produtos que servissem a várias funções e ocupassem pouco espaço. A questão não era se a mobília representava os padrões internacionais de design, mas se era conceitualmente moderna e, de qualquer forma, não necessariamente moderna na sua aparência.

Paralelamente, a sociedade encontrava-se em condições de adotar as mudanças na qualidade de vida promovidas a partir da pro- 
dução estandardizada de mobiliário adaptável e racional e, ainda, em termos de mobiliário e design, do diálogo que se iniciou entre a educação em design e a indústria.

As casas sem dúvida haviam se convertido no principal terreno de experimentação de um racionalismo europeu, mas que objetivamente não se desenvolveria na Finlândia até o final da Segunda Guerra Mundial. Agora havia um entendimento maior em termos de arquitetura e de design, e consequentemente um entendimento do ambiente (casa e mobília) como um todo, e isso era válido desde a classe média baixa até a elite. Ironicamente, ao mesmo tempo a mobília passou a ter influências vernaculares, a abordagem mais dogmática do Modernismo dos anos 1930 foi suavizada e tornou-se mais romantizada, em uma espécie de reação ao período de austeridade da guerra. Desta forma, os designers de mobiliário não se tornaram parte do culto nacional aos designers no pós-guerra, apesar de o mobiliário ter tido um papel significativo em termos do volume de exportações. Apesar dos prêmios recebidos em exposições internacionais, parece que aquele não tinha a áurea mística de outras áreas das artes aplicadas, particularmente a da arte em vidro.

A indústria finlandesa de mobiliário, que tinha tido sucesso em exportações durante os anos 1930, ficou em uma posição complicada com o final da Segunda Guerra Mundial. Os Estados Unidos, como modelo de êxito e prosperidade, converteram-se no modelo cultural de uma Europa rota e empobrecida, e a Finlândia viu-se em uma complicada situação geopolítica, lutando para não ser marginalizada pelas potências aliadas. Desta forma, foi de suma importância estabelecer relações comerciais com os Estados Unidos. A situação começou a se alterar quando as restrições impostas foram gradualmente sendo derrubadas no final da década de 1940. Com o poder de compra da população melhorado, a indústria podia oferecer o mobiliário tradicional de acordo com os padrões convencionais dos consumidores, assim como os produtos de pequenas fábricas carregados das tendências de modernização que haviam sido interrompidas pela guerra. Como exemplo temos o mobiliário 
projetado por Alvar Aalto, até hoje em produção e comercializado com exclusividade pela Artek. ${ }^{8}$

Um dos melhores exemplos do sucesso do design finlandês pósguerra - baseado no conceito moderno "bom, bonito, barato" - éa cadeira Domus (Figura 20), projetada em 1946 por Ilmari Tapiovaara. Versátil, com várias versões, para locais privados, públicos ou institucionais, para ser produzida em massa e com baixo custo de produção. Produzida em partes, era fácil de ser montada e barata para ser transportada. Consequentemente, tinha baixo custo de exportação. A cadeira, parte de um projeto de desenho de interiores realizado em meio à escassez do pós-guerra, cristalizou e provou a validade das metas abordadas por Tapiovaara a partir de meados dos anos 1940, e começou a distanciar-se de seu contexto original até converter-se em uma verdadeira peça de referência, inclusive no mercado internacional, transformando-se em um sucesso. Foi comercializada nos Estados Unidos a partir de 1951 com o nome de Finnchair. A experiência também significou a constatação de que se podia criar o discurso de todo um projeto ao redor de uma peça básica de mobiliário.

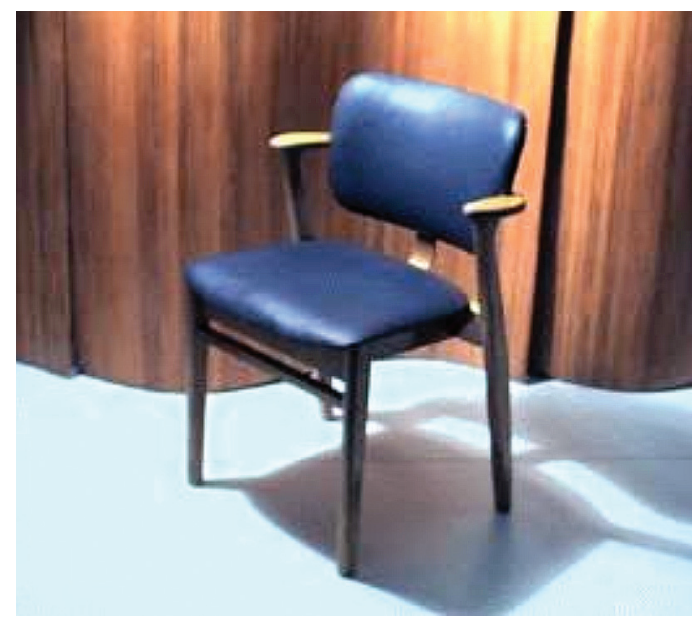

Figura 20 - Cadeira Domus.

8 Disponível em: <http://www.artek.fi/en/about.html>. Acesso em: abr. 2007. 
O mobiliário para escritórios tem sido constantemente ignorado nas análises da relação entre modernização e o design finlandês de móveis. Várias companhias de móveis surgidas no pós-guerra e que se expandiram nos últimos anos começaram produzindo mobiliário para escritórios durante a reconstrução. Por meio da aplicação de técnicas de gerenciamento que enfatizavam eficiência, o trabalho nos escritórios estava bem próximo da modernização da indústria, da força de trabalho e dos procedimentos administrativos. Por exemplo, a companhia Asko (Figura 21), responsável pela produção da cadeira Domus, começou suas operações fazendo mesas para escritórios, e depois mudou o foco para o mobiliário residencial.

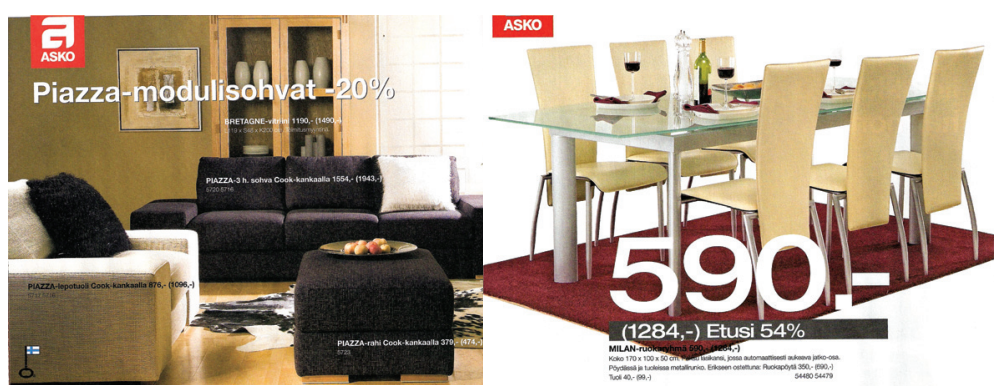

Figura 21 - Exemplos atuais do mobiliário produzido pela Asko.

Outro exemplo é a Skanno, ${ }^{9}$ uma companhia pequena, com uma reputação de moderna, e que começou suas atividades em 1946 com a manufatura de mobiliário para escritórios e depósitos.

A separação definitiva do design moderno de mobiliário das outras áreas do design na Finlândia veio nos anos de 1950. A produção para exportação cresceu significativamente durante esse período, principalmente para a então Alemanha Oriental, o que durou até o final da década de 1990, sendo as principais companhias a Asko e a Isku (Figura 22).

9 Disponível em: <http://www.skanno.fi/index_en.html>. Acesso em: fev. 2007. 



Figura 22 - Exemplos atuais do mobiliário produzido pela Isku.

Ambas as companhias produzem até hoje em larga escala, e principalmente em termos modernos, ou projetos que tenham sido adaptados à estética moderna. Entretanto, sem nenhum entendimento do papel do design e do designer. Por outro lado, algumas das companhias já citadas, pequenas, mas de alta qualidade, como a Artek, a Skanno e a Avarte, ${ }^{10}$ mediante o sucesso internacional em exposições como a Design in Scandinavia, de 1954 até 1957 nos Estados Unidos e no Canadá, e na Milan Triennials nas décadas de 1950 e 1960, fizeram a reputação finlandesa de inovação em mobiliário e a prosperidade do mercado doméstico nos anos 1960 e 1970. Nesse período, muito pouco mobiliário foi importado, e os produtos disponíveis no mercado internos facilitaram a modernização dos lares finlandeses, ajudando a criar uma imagem coerente entre a Arquitetura e outras áreas do design.

A evolução do mobiliário, de lâmpadas, de objetos utilitários e de elementos de decoração de interiores para produtos das artes aplicadas, com um valor intrínseco independentemente do design

10 Disponível em: <www.avarte.fi>. Acesso em: abr. 2007. 
de interiores em geral, foi particularmente sublinhado nos anos da década de 1950. A classe média urbanizada estava, então, pronta para mobiliar suas casas com os itens do repertório formal que ficou conhecido como os "anos dourados" do design finlandês. A arquitetura, a mobília e outros objetos domésticos seguiam claramente a estética das formas funcionais.

Desde os anos 1960, o mobiliário finlandês e seu design têm claramente refletido dois pontos de partida ou abordagens. Por um lado, havia o mobiliário projetado como elemento do design de interiores, e por outro, havia os itens individuais do design de móveis. O mobiliário baseado em objetos individuais é caracterizado por suscetibilidade a tendências afinadas com o espírito dos tempos, e alguns dos modelos acabaram, mais tarde, por se transformar em clássicos.

Desde a década de 1930, são os mesmos materiais e tecnologia de produção que estão disponíveis tanto no design como na manufatura de mobiliário moderno na Finlândia. Em termos de legado do design moderno, nenhuma inovação significante foi introduzida desde os anos 1960.

Uma peça de mobília finlandesa deve ser prática, bem construída, despretensiosa e elegante. Pode misturar-se naturalmente em qualquer tipo de ambiente. Assim, o "look" finlandês em mobiliário nos anos 1960 não foi um estilo rígido, ditado pela moda. Manifestou um desejo de produzir mobiliário sem ideias preconcebidas, mobiliário o qual pudesse satisfazer a demanda variada daqueles dias. A produção preocupava-se basicamente em disponibilizar um mobiliário de qualidade dentro do alcance econômico de qualquer cidadão.

Ao mesmo tempo em que os novos materiais e o plástico deram aos designers a oportunidade de fazer formas flexíveis e usar praticamente todas as cores imagináveis, a história dos materiais sintéticos, particularmente do plástico, ilustra como os designers finlandeses eram limitados por restrições internas da tecnologia e da produção industrial. Logo após o término da Segunda Guerra Mundial, os designers finlandeses Eero Saarinen e Charles Eames 
- assim como os norte-americanos - começaram a usar o plástico de uma forma única, sem emendas, para fazer os assentos, encostos e braços das cadeiras que projetavam. Mas na Finlândia, no final dos anos 1940 e início dos anos 1950, esse material não estava de fato disponível, e os designers experimentaram o uso do compensado curvado para chegar ao mesmo resultado formal de seus contemporâneos norte-americanos, mas baseando-se em uma técnica completamente diferente. Quando o plástico finalmente tornou-se um material viável, este apareceu primeiramente apenas sob a forma de acrílico, cujas propriedades físicas e o alto custo limitavam o uso. Entretanto, quando era combinado com uma malha metálica, tornava-se perfeito para a estética ditada pelo Modernismo. Mas ainda assim a técnica da fibra de vidro laminada ou o uso do poliestireno requeriam um extensivo trabalho manual. Foi apenas com a introdução do uso de poliuretano (que era menos caro e podia ser prensado num molde) que o plástico começou a ser usado, a partir de meados da década de 1960, para fabricar cadeiras com um preço mais acessível.
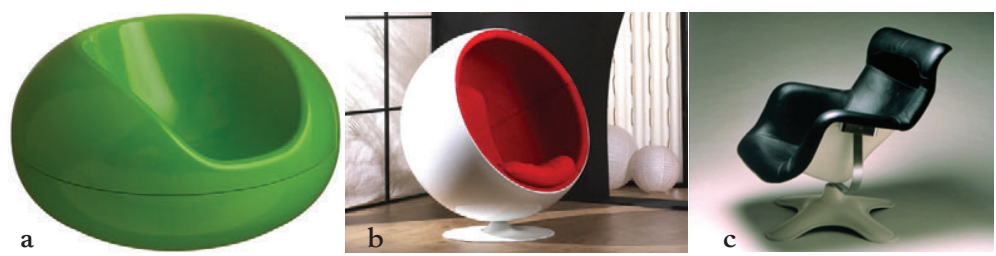

Figura 23 - Peças como Pastilli (a) e Ball Chair (b), de Eero Aarnio, e Karuselli (c), de Yrjö Kukkapuro, eram inovadoras e expressões distintas de seu tempo - assim como a maioria das cadeiras modernas de plástico do final da década de 1950 e início dos anos 1960 - e foram bem recebidas internacionalmente, mas eram caras e passíveis de serem produzidas apenas em pequenas séries.

Apesar de ser insignificante em termos de produção, a manufatura recebeu bem esses designers, porque eles tinham um valor de imagem, uma qualidade experimental. O início do uso dessa mobília inovadora em interiores institucionais foi lento, e apenas no final 
da década foram feitos interiores coloridos e imaginativos, particularmente em restaurantes, escolas, livrarias e pequenos bancos.

Duas décadas após a cadeira Domus, a cadeira Polaris (Figura 24), de Eero Aarnio e produzida pela Asko em 1966, da qual foram produzidas mais de um milhão de unidades, repete em plástico o que Ilmari Tapiovaara tinha criado antes em madeira sólida e madeira compensada: um design moderno e ergonômico.

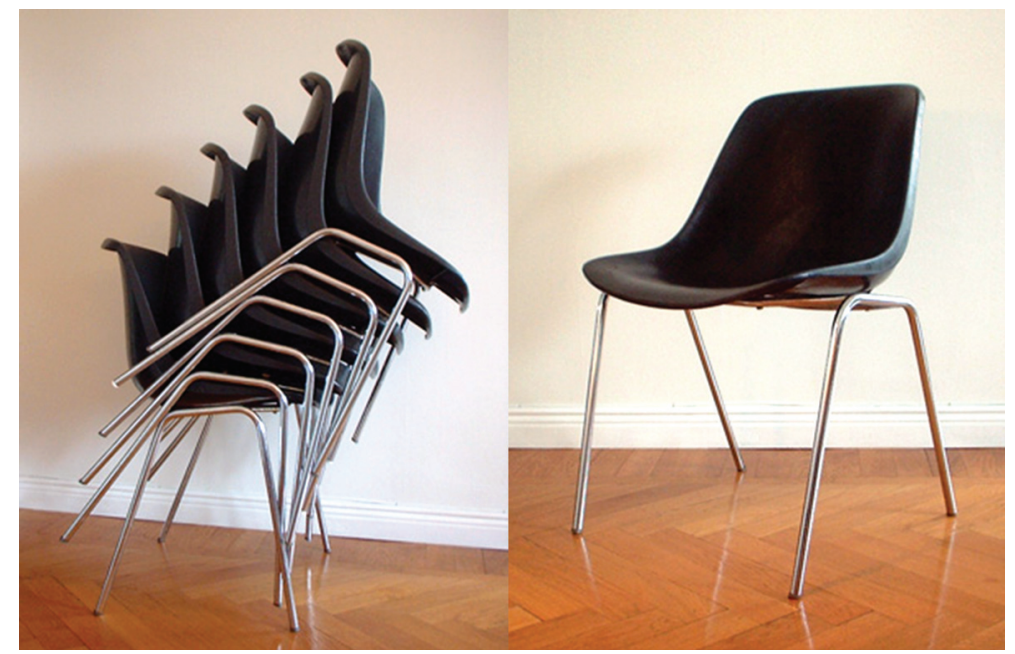

Figura 24 - Cadeira Polaris.

Produzindo cadeiras com pernas metálicas tubulares, com assento e encosto em plástico, como um anônimo objeto utilitário, várias manufaturas de móveis realizaram um dos principais objetivos do Modernismo: nova tecnologia combinada com uma forma moderna que era produzida em grande escala e a baixo custo. $\mathrm{O}$ sonho dos primeiros modernistas de produzir um ambiente residencial padronizado tinha finalmente se tornado realidade. Mas o grande número de cadeiras de plástico que surgiu no mercado contribuiu para o anonimato do design. Cadeiras de plástico tornaram-se objetos cotidianos da cultura de massa, isenta dos ditames ideológicos 
que tinham contribuído para sua realização e até pouco associada com designers famosos.

A popularização dos plásticos na indústria moveleira na Finlândia durou até meados da década de 1970. A próxima geração de designers de mobiliário moderno começou sua carreira no final dessa década, durante os anos da crise de energia. Plástico e metal estavam fora de uso, e a madeira local novamente voltou à cena. $\mathrm{O}$ design finlandês tornou-se mais regional e interessado em um revival do estilo de vida rural e étnico. Novas e mais avançadas técnicas de laminação gradualmente permitiram à madeira substituir o plástico no mobiliário para espaços públicos. As exportações focavam-se na antiga União Soviética, fato que foi também responsável pelo declínio do investimento em design. Tendo um mercado fechado com um cliente, as manufaturas finlandesas não tinham necessidade de ser inovadoras.

No final da década de 1960, o vocabulário formal minimalista e as cores claras, normalmente entendidas como a natureza própria das tendências estilísticas largamente adotadas em mobiliário, abriram caminho para uma mobília inspirada no pop internacional, com o emprego de formas irregulares e/ou geométricas e cores fortes e/ ou contrastantes. Essa tendência, expressada por meio da informalidade e rebeldia contra os valores da classe média, refletia as mudanças no design finlandês e as respectivas técnicas de produção. $\mathrm{O}$ divisor de águas no final da década envolveu tanto mudanças ideológicas como de geração. Os ideais da era pós-guerra estavam sob severa crítica. De modo geral, a dimensão social do Modernismo voltava à cena novamente, e o design oficial era criticado por esquecer esses princípios. Em outras palavras, os modelos adotados eram acusados de heresia ideológica. Visto dessa perspectiva - a ênfase do design de mobiliário nos anos 1970 no consumidor e nos princípios de igualdade social, economia e ecologia -, dava continuidade ao grande projeto do Modernismo, embora externamente alterado em suas formas. Entretanto, a cruzada ideológica e o boom econômico conduziram a uma divisão entre o designer de elite - com seus princípios - e os consumidores. As mudanças eram manifestadas 
no retorno à noção tradicional de uma sala finlandesa com estantes e armários históricos e sofás barrocos, e nas cozinhas, mesas inspiradas nas formas vernaculares.

Esse fenômeno era associado a mudanças socioculturais na sociedade finlandesa, tais como a extremamente rápida urbanização e o crescimento da influência internacional nas escolhas locais. A cultura do Modernismo, que por um momento pareceu tão permanente e transcendia as classes sociais, tinha mudado fundamentalmente. Desde os anos 1970, o mobiliário que ganha prêmios e é elogiado como o novo design finlandês tem muito pouco a ver com o mobiliário adquirido pelos consumidores finlandeses para suas casas.

O que se notou nos anos 1980 foi uma forte e consistente oposição na arquitetura e no mobiliário finlandeses a tendências como o Neo-Historicismo Norte-Americano ou o Neo-Clássico e o Grupo Memphis, da Itália. Contudo, entre a tentativa de retorno aos ideais modernistas e a proposta dos designers da década de 1980 houve uma lacuna, pelo menos em parte. A geração que estava agora no comando era aquela que se posicionara contra os líderes do pósguerra nos anos 1960 e 1970. A nova geração dos anos 1980 tentou iniciar seu próprio protesto, mas a estrutura social vigente não os apoiou da mesma forma que em outros momentos. Cegado pelo boom econômico, e com uma orientação extremamente comercial e individual, o mobiliário industrial dos anos 1980 procurou produzir estrelas do design à la Philippe Starck. Assim, uma nova era de individualismo começou em meados da década de 1980. O Pós-Modernismo que vinha da indústria de mobiliário italiano introduziu a experimentação, uma busca por coisas novas e uma nova imagem de cor e forma. Os materiais locais eram característicos, e apesar desse natural ponto inicial, o resultado foi definitivamente uma imagem contemporânea e original, a qual, na melhor das hipóteses, estava apta a competir em pé de igualdade com as tendências internacionais das manufaturas. A imagem da fresca luminosidade nórdica, acentuada por texturas coloridas, em um espírito contemporâneo, gerou grandes elogios, assim como o interesse de vários usuários e compradores, e grandes quantidades de mobília finlan- 
desa foram exportadas nos anos 1980. O mobiliário para espaços públicos, em particular, assim como mobiliário para escritórios, tiveram de um novo boom com a construção civil e a decoração de muitos prédios públicos novos, centros culturais, prefeituras e prédios de escritórios.

Quando o mercado da antiga União Soviética desapareceu, a indústria finlandesa de mobiliário enfrentou problemas. A Escandinávia e a Finlândia não tinham mais a mesma reputação de good design nos mercados europeus integrados ao novo contexto global. Assim como nos anos pós-guerra, a indústria moveleira finlandesa não demorou a assumir os riscos e/ou recrutar designers para criar produtos inovadores. Mas, em vários aspectos, o design finlandês moderno de móveis e sua produção, cuja história do pós-guerra havia aproximado, criando um estado de prosperidade, tinham chegado a um divisor de águas. A sociedade e a economia que tinham inspirado, sustentado e guiado seu desenvolvimento encontrava-se em uma encruzilhada similar.

A década de 1990 testemunhou um retorno parcial à manufatura artesanal de mobiliário em pequenas séries, especialmente em madeira maciça. Materiais locais, naturais e simples, e formas práticas constituíram a linha mestra do mobiliário em madeira dos anos 1980,e, particularmente, na década de 1990, com uma grande variedade de materiais, formas, cores e técnicas. O mobiliário experimental e conceitual, apresentado por jovens designers, como protótipos ou autoprodução em pequenas séries, recebeu grande e significativa atenção, especialmente da imprensa internacional. $\mathrm{O}$ mobiliário finlandês foi "redescoberto" depois da recessão e morosidade do início dos anos 1990.

Com a ajuda de subsídios econômicos, educação e de competições, surgiu uma nova geração de designers de móveis atentos às tendências internacionais e familiarizados com os processos de fabricação. No final do século XX, o designer freelance, independente e autônomo, colaborando com várias manufaturas, tomou o lugar da relação de longa data entre designers e companhias. Os jovens designers de mobiliário começaram inclusive a produzir e 
a comercializar seus produtos. As características locais não eram mais a temática explorada, mas a globalização, a sociedade informacional, cosmopolita, nômade e urbana forma - entre outros - os termos usados como justificativa para unir os jovens designers e seus produtos, resultado das mudanças na sociedade, com a rápida expansão da informação tecnológica, da globalização da economia de mercado e da nova Finlândia europeia. Tudo isso se refletiu no modo como os jovens designers criavam, produziam e comercializavam seus móveis. O conceito do produto particular caracterizou o mobiliário do final dos anos 1990.

A era do mobiliário utilitário, manufaturado, seriado, e os elementos do design de interiores têm dado lugar a itens de mobiliário de experimentação individual ou a pequenas séries de produtos orientadas para o mercado. A individualidade anterior de design de interiores único tem sido agora substituída pela individualidade em um sentido experimental, conceitual e até abstrato. Itens de mobiliário têm sido objetos de design distintos, sem nenhuma ligação com o tempo, lugar ou local. É evidente no design finlandês contemporâneo o produto em um contexto cultural e histórico, o Modernismo revisitado; novas interpretações do Modernismo, em um contexto social que seja mais amplo do que um contexto real do uso. Os produtos do design atual podem ser interpretados como representações da cultura finlandesa e, desse modo, ligados às suas raízes históricas e aos vários pontos de vista sociais.

O ponto de vista finlandês leva em consideração que as pessoas podem ter ideias diferentes sobre mobiliário. Algumas têm claramente uma visão utilitária e pensam apenas nas funções práticas e na durabilidade do móvel. Outras querem um mobiliário com um design moderno, enquanto um terceiro grupo pode enfatizar o conforto charmoso associado com uma mobília de estilo mais tradicional.

Outra característica da produção finlandesa de mobiliário é que esta se desenvolveu em uma frente internacional. Todos os envolvidos tinham trabalhado para a realização da meta "excelência cotidiana”. Naturalmente, alguns designers atuaram individualmente, 
mas, como um todo, a produção de mobiliário foi sustentada pela combinação dos esforços da manufatura, dos designers, das pesquisas, da tecnologia, da conceituação teórica dos interesses do público-alvo e, finalmente, pelo interesse do consumidor propriamente dito.

A posição bastante especial do mercado de mobiliário finlandês depende também da estrutura do mecanismo de produção. $\mathrm{Na}$ realidade, a mobília é produzida por um número muito grande de pequenas fábricas.

Do ponto de vista da eficiência, a divisão em tantas pequenas unidades é naturalmente uma desvantagem. Como compensação, várias pequenas companhias agrupam-se em torno de uma, mas cada qual continua produzindo sua própria especialidade. Mas existem vantagens em separar a produção. Por exemplo, elas não são completamente dependentes de que um único produto seja um grande sucesso de público, e podem experimentar e variar seu design, assim, sucessivamente, adaptando-se ao mercado constantemente em mudança. Isto acontece sem ninguém dizendo o que tentar para acompanhar os ditames da moda. Mas é lógico: é impossível eliminar isso completamente. Observando a produção atual, não se pode negar que o sucesso no mercado estrangeiro induziu alguma fábrica a especular uma moda, um "estilo" finlandês. Mas em princípio, um design deve ser alterado apenas quando novas demandas em mobiliário o tiverem tornado obsoleto.

O padrão de se morar é uma forma de cultura a qual necessita ser enriquecida, e não deve ser não explorado o modo de viver do homem cotidiano. Improvisações no padrão de vida ocorrem muito lentamente dentro do confinamento da produção em massa. Uma pessoa deve poder determinar seus próprios ambientes de acordo com suas necessidades individuais sem perder as vantagens fundamentais inerentes à produção em massa. $\mathrm{O}$ futuro pertence aos designers, para quem projetar é uma compreensiva missão apontada para o avanço do desenvolvimento social. 



\section{4 \\ DESIGN BRASILEIRO: ANTECEDENTES HISTÓRICOS}

Na época em que o ensino formal de design foi implantado no Brasil, já datava de quase um século e meio o conflito sobre o papel da arte aplicada à indústria como agente de desenvolvimento econômico, e a tarefa desenvolvimentista tem continuado a ser um desafio constante para o campo do design ao longo da história recente brasileira, com surtos cíclicos de renovação de interesse pelo tema a cada geração. A criação, em 1996, do Programa Brasileiro de Design $^{1}(\mathrm{PBD})$ e de programas estaduais congêneres de promoção do design insere-se na mais recente etapa dessa longa trajetória, afirmando a continuada crença no poder do design como elemento estratégico capaz de agregar valor à produção industrial nacional. Entretanto, ao longo dessa evolução histórica tem permanecido pouco claro de que maneira o design iria servir de alavanca para as transformações almejadas.

Começando nos anos 1940 até o final do século XX, pode-se distinguir duas grandes tendências: a primeira é constituída daqueles que trabalhavam como se estivessem na Europa, e a segunda, daqueles que entenderam que ser brasileiro quer dizer alguma coisa

1 Disponível em: <http://www.designbrasil.org.br/portal/index.jhtml>. Acesso em: set. 2008. 
de muito especial, mas que não conseguiram dizer em que consistem os elementos dessa diversidade.

Havia ainda a mentalidade de que não adiantava o Brasil investir em design, por ser um país periférico no sistema econômico mundial e cuja função dentro de uma divisão de trabalho internacional seria de servir como exportador de matérias-primas e, no máximo, de produtos industriais de baixa tecnologia. Trata-se também de uma tese antiga, datando pelo menos do século XIX, quando muitos argumentavam que o Brasil nem deveria tentar se industrializar por ser um país de vocação eminentemente agrícola.

Entretanto, segundo Moraes (2006), com a industrialização maciça dos últimos cinquenta anos, a tese da "vocação agrícola" teve de ser alterada significativamente para dar conta da nova realidade. E de tanta alteração, acabou sofrendo uma inversão, e em vez de ser utilizada para combater a industrialização, suas premissas fundamentais foram aproveitadas por outros segmentos ideológicos para promover uma intensificação da evolução industrial. A partir da voga por teorias de sistemas mundiais nos estudos sociológicos das décadas de 1960 e 1970, surgiu uma série de críticos propondo que países como o Brasil não conseguiriam passar para o chamado estágio desenvolvido porque eram mantidos propositalmente em uma situação de atraso industrial e dependência tecnológica. Para esses críticos, a grande questão política mundial seria a transferência de tecnologia dos países mais avançados para os países mais atrasados, o que resultaria em uma explosão de crescimento destes últimos e uma maior igualdade entre todos, e essa ideia da transferência de tecnologia exerceu uma influência bastante importante sobre o campo do design.

Não se deve, nesse contexto, subestimar o papel das empresas multinacionais junto ao modelo de modernidade consolidado no Brasil. Essas empresas, por meio da transferência de suas práxis produtivas do norte para o sul do planeta, trouxeram também diferentes elementos para o quebra-cabeça brasileiro, e isso teve consequências tanto negativas quanto positivas.

No Brasil, onde boa parte da produção industrial fica a cargo de empresas multinacionais, tem existido, desde há muito, uma nítida 
insatisfação por parte da comunidade dos designers com a política da maioria dessas empresas de importar projetos diretamente da matriz estrangeira, o que poderia ser considerado uma demonstração clara da relação de dependência em ação.

Todo o esplendor do boom econômico e da forte industrialização alcançada pelo Brasil no final dos anos 1970 não se estendia para o âmbito do design industrial local, não obstante a evolução em setores que despontaram isoladamente. A situação geral do desenvolvimento industrial no Brasil não correspondia ao desenvolvimento do design.

Os empreendedores locais, por vez, considerando suas condições de fornecedores ou partners (através da produção associada) das multinacionais instaladas no Brasil, enxergavam nas empresas centrais o melhor exemplo a ser seguido e faziam-se valer do design local somente por meio das imagens gráficas e dos catálogos promocionais de seus artefatos industriais. Uma aplicação bastante reduzida, diante da grande expectativa existente por parte dos designers brasileiros, que se propunham a operar dentro do âmbito do design, no sentido mais amplo e alargado possível do termo. Esse fenômeno também explica, em parte, a maior evolução no território brasileiro da atividade de design gráfico (visual design) em detrimento do design industrial (product design).

O conceito de produto vernacular ou autóctone disseminado mediante o conceito de tecnologia alternativa já existia no Brasil antes mesmo dos ideais dos ecologistas. O que sucedeu, na realidade, como fator de inovação, no âmbito do design brasileiro, foi a absorção e promoção dos ideais da tecnologia alternativa de forma mais ordenada e como uma resposta contra o modelo de industrialização ocidental. Ou seja, a tecnologia alternativa foi, então, elevada à condição de instrumento de protesto contra o modelo "colonialista industrial" predominante.

As variadas características e as diversidades regionais nitidamente presentes poderiam ter sido tomadas como possíveis referências projetuais. Mesmo que algumas tentativas nesse sentido tenham ocorrido no Brasil, o modelo racional-funcionalista venceu 
e tornou-se predominante como modelo único e de base para a instituição do design em praticamente todo o país.

Nesta análise sobre o fenômeno funcionalista na realidade do design brasileiro, desponta um outro componente bastante interessante: a frágil presença ou quase negação do espírito lúdico, carnavalesco e festivo local, da ingenuidade e da utopia, do sacro e do profano existentes como fortes características da cultura brasileira, bem como dos dramas e das imperfeições da cultura latino-americana. Optando de maneira generalizada pelo modelo racionalista, o design brasileiro inibiu as referências locais em sua constituição, que deveriam, de outro modo, fundamentar a criação de uma linguagem própria.

O design brasileiro sustentou, então, desde o início da instituição oficial de seu ensino, o modelo racional-funcionalista moderno como referência maior para guiar o país rumo à industrialização e, mais importante ainda, para fora de sua condição de periferia, subdesenvolvimento e pobreza. Mas, na realidade, seguir o rumo racional-funcionalista dificultou a inserção dos ícones da cultura local brasileira em sua cultura material e em seus artefatos industriais. E ainda, ironicamente, não foi esse modelo racionalista que colocou a produção nacional no cenário mundial, e sim aquele que valoriza nossas características locais.

Assim, é importante, neste contexto, observar-se com atenção a natureza híbrida do design. Conforme salienta Loschiavo dos Santos (1995) em seus estudos sobre o processo de modernização do móvel no Brasil, apesar das inegáveis influências trazidas à produção de mobiliário por meio da importação de móveis de outros países e de correntes como as do "bom desenho" da Bauhaus e da Escola de Ulm, entre outras, é possível identificar-se, no caso do design brasileiro de móveis, soluções técnicas e estéticas com características "mais brasileiras", que se manifestaram sobretudo a partir do final da Segunda Guerra Mundial. O design do móvel brasileiro conjugou ideias e conceitos do Movimento Moderno e de elementos nacionais, como, por exemplo, "os tecidos, as fibras naturais e o uso de outros materiais da terra". 
Após o pioneirismo das décadas de 1920 e 1930, notadamente na figura de Gregori Warchavchik, ${ }^{2}$ a década de 1940 viu surgirem profissionais que realizaram desenhos de móveis e outros equipamentos de habitação, com propostas para a indústria nacional, principalmente após a Segunda Guerra Mundial, preocupados em produzir móveis com características mais brasileiras - principalmente em relação ao clima e aos materiais empregados -, gerando pesquisas em torno das matérias-primas nacionais - madeiras e/ou tecidos - até chegar à produção em série.

A partir da década de 1950, o Brasil viveu um progresso singular. Sob o slogan "cinquenta anos de progresso em cinco", de Juscelino Kubitscheck, surgiram Brasília ${ }^{3}$ e outros projetos ambiciosos. Esse cenário econômico favorável incentivou a abertura de novas empresas e propiciou o aparecimento das primeiras iniciativas de design, tais como a Móveis Preto \& Branco, a Unilabor, a Oca, entre outras (Figura 25). Assegurados os novos princípios do móvel, por meio de uma produção praticamente artesanal, inicia-se uma série de experiências de desenho/execução industrial que trouxe ao móvel moderno brasileiro uma maturidade que o colocou em destaque no panorama internacional.

O Movimento Moderno no Brasil foi, por muito tempo, sinônimo de industrialização e prosperidade, mas com o golpe militar de 1964, interrompeu-se o sonho socialista do projeto modernista, identificado com a resolução dos problemas sociais do país.

Diante dessas considerações, segundo Moraes (2006), pode-se levantar a hipótese de que a experiência da tecnologia apropriada surgiu primeiro na periferia, desenvolveu-se como conceito nos

2 Arquiteto de origem russa que se radicou no Brasil a partir de 1923, conhecido como o introdutor da arquitetura moderna no Brasil. Reconhecia a importância do design e suas relações com a Arquitetura. Exemplo disso é a Casa Modernista, onde ele lançou bases para a reformulação dos espaços, dos programas arquitetônicos e do próprio móvel com a implantação de uma nova concepção estética arquitetônica que incluía também o móvel.

3 Oscar Niemeyer projetou não apenas os edifícios para a então nova capital do país, mas também o mobiliário para os edifícios públicos. 

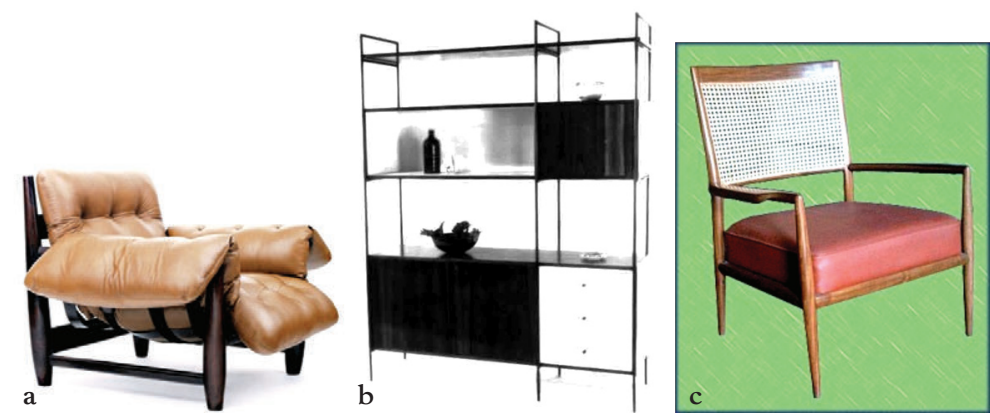

Figura 25 - Poltrona Mole (1961), de Sérgio Rodrigues (a). Projeto de Geraldo de Barros para a Unilabor (b). Projeto de Carlos Millan para a Móveis Preto \& Branco (c).

países de industrialização mais madura e retornou como modelo projetual para o design da periferia, passando a se apresentar também como panaceia para os problemas produtivos e tecnológicos dos países periféricos.

A proposta de uma política tecnológica voltada para o uso de materiais e mão de obra locais, respeitando condições existentes de aplicação e dependendo de baixos custos de investimento, logo ganhou adeptos no meio intelectual brasileiro, ainda mais porque contrastava com a política tecnocrática agressiva dos governos militares, que apostavam crescentemente em aviões, satélites e reatores nucleares como símbolos do progresso nacional. Na década de 1980, com o reconhecimento gradativo do fracasso da proposta modernista para a transformação da sociedade brasileira, começou a ganhar destaque uma preocupação mais explícita com a ideia de um "design social", mas permaneceram incipientes as experiências nesse sentido. A experiência brasileira da tecnologia alternativa e apropriada, não obstante o debate sociopolítico e humanístico, não trouxe solução para os problemas e os desafios que precisavam ser enfrentados pelo design local.

Uma das áreas mais problemáticas para a afirmação do papel social do design no Brasil tem sido a relação dos designers com o Estado como foco de atuação e como parceiro. O Estado brasileiro 
tem exercido uma forte influência como agente de fomento e de transformação da nossa realidade social e cultural. Aliás, quase todas as grandes mudanças nessas áreas têm passado pela intervenção estatal, e só muito recentemente começou-se a perceber uma disposição da sociedade civil em intervir mais diretamente na organização de iniciativas que envolvam pouca ou nenhuma colaboração do poder público. Portanto, é natural que alguns designers tenham seguido os passos de tantos artistas, arquitetos e engenheiros que os precederam e tenham buscado no âmbito estatal oportunidades poucas vezes disponíveis no setor privado.

A começar pela criação da própria Escola Superior de Desenho Industrial - ESDI ${ }^{4}$ e estendendo-se ao estabelecimento de faculdades de design em um grande número de universidades públicas; uma das áreas mais importantes de colaboração entre design e poder público tem sido no campo do ensino. Nessa área, porém, o que costuma entrar em questão é mais a relação do Estado com a universidade como um todo, em cujos rumos o design tem exercido um papel pequeno e geralmente tímido. A outra grande instância de colaboração do designer com o poder público tende a ser como contratado ou prestador de serviços. Para alguns designers - como para alguns publicitários -, o Estado apresenta-se como um importante cliente, com o poder de distribuir contratos de visibilidade e prestígio.

Os ideais da cultura pós-moderna chegaram ao Brasil em momento de baixa autoestima do design local, que se encontrava entre o desprezo das multinacionais e a miopia das empresas locais, que não percebiam a importância de sua aplicação para a diferenciação dos artefatos industriais. Por isso mesmo não pode ser esquecida, mas, ao contrário, deve ser salientada, a importância do fato de que os ideais da cultura pós-moderna chegaram ao Brasil justamente na década em que terminou o longo período de mais de vinte anos da ditadura militar.

4 Disponível em: <http://www.esdi.uerj.br/>. Acesso em: set. 2008. 
Os designers brasileiros, por sua vez, assumiram o pensamento pós-moderno como uma bandeira de protesto contra o estado da arte do design local, que não conseguia instituir-se de maneira autônoma e definitiva, mantendo-se sempre como um modelo de esperança. Os designers e estudantes brasileiros utilizaram da mesma forma os "rumores" do pós-moderno contra a indiferença das multinacionais, com suas estratégias de fácil lucro e grande desprezo pela causa e razão de nosso design local.

Mas os rumores do pós-moderno brasileiro atingiam também os próprios empreendedores do país, que não se monstravam sensíveis à importância da inclusão do design na produção industrial local. As empresas brasileiras, em sua prática de constante mimese do exterior, não tomaram como desafio decodificar os valores culturais locais e inseri-los, por meio da atividade do design, na produção de massa dos nossos artefatos industriais. Esse fato contribuiu para alargar ainda mais a distância entre estes últimos e os diversos aspectos da identidade cultural brasileira.

Por tudo isto, pode-se afirmar, de acordo com Moraes (idem), que a condição pós-moderna no design brasileiro reflete-se também como uma manifestação política em favor da liberdade de expressão e contra a insatisfação então vivida. Entenda-se: o regime militar e as fortes influências do exterior sobre o sistema de produção industrial local. No Brasil, podemos afirmar que esse movimento não se prefigurou somente como sendo pós-moderno, mas também como pós-militar, pós-autoritário e de pós-austeridade.

É claro que a cultura pós-moderna, por si só, não era capaz de resolver todos esses problemas de grande complexidade e acentuada relevância. Não pretendia o pós-moderno nem mesmo ser um novo modelo de produção industrial local em um cenário já previamente definido pelas próprias multinacionais. Mas o movimento manifestava-se como um desafogo de uma inteira geração de designers que se encontrava enclausurada e submetida a um modelo visivelmente não mais condizente com a realidade então vivida. Recorda-se que, nesse sentido, o percurso do Movimento PósModerno no Brasil torna-se mais próximo da prática contestatória 
da contracultura surgida precedentemente nos Estados Unidos e na Europa, justamente pelo fato de que entre as propostas do pensamento pós-moderno - europeu, principalmente - encontrava-se aquela de contraposição ao modelo de produção industrial convencional vigente.

Assim, o design brasileiro do modelo pós-moderno dos anos 1980 não produziu em quantidade significativa, mas iniciou um novo processo para o reconhecimento de uma estética brasileira multicultural e mestiça. Foi aberta, então, uma nova e possível estrada para o design por meio da decodificação do próprio pluralismo étnico e estético local, cujo modelo, em sua forma mais madura, desponta somente a partir da segunda metade dos anos 1990.

A nova realidade conduziu a esse novo modelo, que começou a pôr em evidência uma estética múltipla, em que se nota uma forte presença dos signos híbridos e de uma energia particularmente brasileira. A heterogeneidade local desta vez é aceita no design brasileiro como aspecto positivo, um espelho do mix social existente. Um design plural, que tem origem nas diversas culturas existentes dentro do país.

Entretanto, o ideal pluralista do design brasileiro continua a apresentar muitos desafios, uma vez que se desenvolve em uma sociedade cujos maiores conflitos foram, e ainda são, gerados pela complexidade de decodificação da grande diversidade existente internamente.

É importante perceber que mesmo essa nova estrada tomada pelo design brasileiro traz consigo, ainda que de maneira quase inconsciente, as referências do pensamento racional-funcionalista, por mais de quarenta anos mantidos como dogma no âmbito local. Parte das referências racionalistas sobrevivem, ainda hoje, principalmente por meio de um modelo que aponta para a facilidade da produção industrial. Esse aspecto racional que continua presente no atual design brasileiro permanece como uma espécie de consciência local (herança do projeto de modernidade) sobre a realidade do país, o dilema brasileiro da desigualdade social que ainda não foi de todo resolvido. Ressaltando, entrentanto, que a prática deste 
modelo projetual brasileiro não se coliga mais ao dogmático rigor metodológico predominante no modelo racional-funcionalista até então vigente.

O design brasileiro inserido nesse cenário entre a Pós-Modernidade e o modelo de globalização iminente começa a ter como referência maior a riqueza e a expressividade das próprias manifestações culturais do país. Toma a cultura popular e o carnaval como fantasia coletiva, reconhece o kitsch como gosto popular de massa e as telenovelas como referência ética e estética local. Todas essas transformações que aconteceram dos anos 1980 em diante no Brasil estão muito próximas do pensamento e das referências de uma cultura múltipla que se encontram presentes no modelo pós-moderno e neste atual modelo de globalização.

As transformações ocorridas no Brasil no âmbito do design e da tecnologia produtiva, a partir do período do advento da cultura pós-moderna e da era Pós-Industrial, tomaram forma singular e marcante. Essas novas referências, por um lado, possibilitaram evidenciar os aspectos positivos da multiculturalidade local brasileira, e por outro, preanunciaram o nascimento do modelo de globalização que começou a definir-se somente a partir dos anos 1990.

Neste contexto, segundo Nascimento (2001), a abertura do mercado nacional estimulou empresas a lançarem novos produtos com maior frequência. A revisão das leis de patentes, reflexo da globalização do mercado, teve fortes consequências no processo de desenvolvimento tecnológico nacional. A partir da percepção da necessidade de aumentar a utilização do design como forma de melhorar a competitividade dos produtos brasileiros, foi criado, em 1995, o PBD, uma iniciativa de mobilização dos diversos setores que podem contribuir para uma maior utilização do design.

O fenômeno da globalização, como modelo impreciso e controverso, possibilitou, por meio dos meios tecnológicos e informáticos, uma maior interação entre diferentes povos do planeta, mas também colocou em xeque as especificidades da cultura local, disseminou a incerteza e promoveu radicais transformações no contexto comportamental. 
Com o novo cenário que se estabelece, grande parte dos problemas que existiam somente na esfera local tornou-se global. A nova realidade promoveu o surgimento de novos modos produtivos e de novos bens industriais, desta vez não mais no âmbito apenas de um mercado regional, mas no âmbito de um mercado de abrangência global.

Dentro desse cenário, de acordo com Moraes (2006), o design brasileiro começa a se distanciar da prática de mimese e das referências provenientes do exterior e começa a apontar (fruto, na verdade, do seu percurso e do seu amadurecimento) em direção à uma referência própria como modelo possível. Começam então a surgir, por meio do multiculturalismo e da mestiçagem local, novas referências projetuais que, de forma correta, colocam em evidência e refletem a vasta gama de elementos da cultura híbrida e das nuances de nosso próprio país.

O multiculturalismo brasileiro posiciona-se desta vez como um novo e possível modelo para o desenvolvimento do design local. Esse modelo que se apresentou incipiente e imperfeito por toda a década de 1980 vem se harmonizar com o modelo de globalização que é estabelecido por todos os anos da década de 1990 como último estágio de um percurso rumo à segunda modernidade que se prefigura no mundo ocidental. Essa nova realidade exige também dos designers a consideração do tríplice aspecto: design, cultura e território. Exige, de igual forma, que seja seriamente contemplada a questão ambiental no projeto, o excesso de produtos disponíveis no mercado e também o problema do consumo desenfreado e da produção - o design para a sustentabilidade). Exige que seja observada a causa social - hoje muito diferente daquela debatida no início dos anos 1980 - que coloca no centro do teorema design a questão da terceira idade e das minorias de usuários ainda não contemplados pelas benesses da indústria. Exige a consideração sobre os novos fatores de uso, que se transformaram radicalmente através dos tempos, uma consequência da mudança do comportamento humano dentro da realidade sociocultural circunstante. Da mesma maneira, deve ser considerado o surgimento de novas tecnologias e de novos 
materiais, o conhecimento sobre a cadeia de valores agregados ao design, como o valor de estima e a qualidade percebida dos artefatos industriais.

Enfim, como bem coloca Cardoso (2004), hoje, o maior problema para o design brasileiro é libertar-se de uma vez por todas do complexo de inferioridade que os velhos racionalistas europeus the transmitiram através de um modelo errôneo de desenvolvimento dentro da modernidade e da ordem. Os designers brasileiros devem adquirir consciência de si mesmos como portadores de uma realidade criativa de todo autônoma e original, por meio da qual os velhos defeitos podem se tomar extraordinárias oportunidades. 


\section{5 \\ Panorama ATUAL BRAsileiro}

$\mathrm{Na}$ Sony, supomos que todos os produtos de nossos concorrentes terão basicamente a mesma tecnologia, o mesmo preço, o mesmo desempenho e as mesmas características. O design é a única coisa que diferencia um produto do outro no mercado.

(Norio Ohga, presidente e CEO, Sony)

A incapacidade de articular relações dentro e fora do campo tem contribuído para gerar uma situação que é grave no depoimento sobre a relevância do design em um país como o Brasil. Quase quatro décadas após a abertura dos primeiros cursos universitários de design e da fundação da primeira associação de profissionais da área, o design continua a ser uma atividade relativamente desconhecida para a grande massa da população e, mesmo para as elites, seu potencial de realização permanece pouco explorado. É no mínimo preocupante constatar quão pouco a consciência do design como profissão tem alterado a evolução cultural brasileira ao longo desse período.

Ao examinar-se a paisagem material que nos cerca, deparamonos com problemas crônicos de design em áreas como transportes, saúde, equipamentos urbanos e uma infinidade de outras instâncias 
do cotidiano. Mesmo fora do âmbito dos serviços públicos, em um setor privado voltado por definição para questões de competitividade e dinamismo, percebe-se um desconcerto frequente entre as preocupações da profissão e aquelas da própria sociedade. Será que é a sociedade que teima em não se adequar aos padrões corretos ou será que é o designer que está trabalhando dentro de parâmetros estreitos e ultrapassados?

A persistência e mesmo o ressurgimento do chamado elemento vernacular no design brasileiro é um tema de enorme importância, pois revela as tensões entre uma visão de design fundamentada em ideais importados e uma outra assentada no reconhecimento das raízes profundas da realidade brasileira. Enquanto alguns designers e algumas instituições insistirem em posicionar o campo como um agente de imposição de padrões fixos de gosto ou de distinção social, o design corre o risco de permanecer, até certo ponto, uma flor de estufa no Brasil, incapaz de sobreviver fora do ambiente climatizado do mercado de artigos de luxo.

A nova geração de designers brasileiros que surge agora, relativamente livre das prescrições passadas, parece reconhecer intuitivamente a importância de redescobrir e reinventar os elementos formais, informais e até mesmo informes da tradição nacional de design. Tem surgido nos últimos anos - dentro de uma lógica pósmoderna de apropriação e recombinação - uma série de trabalhos de design que citam aspectos desse legado histórico, seja de forma bem-humorada ou totalmente séria. Após anos de homogeneização visual em nome da modernização, alguns setores comerciais também parecem ter reconhecido finalmente que o público nem sempre dá prioridade ao novo como o elemento mais importante de caracterização da mercadoria.

Partindo de tais iniciativas de recuperação da tradição para uma proposição mais abrangente e sistemática, pode-se dizer que o trabalho de pesquisa em história do design também está inserido no projeto maior de redimensionamento do papel do design na sociedade brasileira. Talvez um dos sintomas mais característicos da dificuldade de forjar um design nacional seja a falta de reconheci- 
mento, por parte dos próprios designers, da existência e do florescimento das atividades projetuais por eles exercidas anteriormente à organização profissional da área na década de 1960. Optando pelo lado menos glamouroso de seu legado histórico, voltando-se para as instâncias comuns e básicas de atuação, atentando para a narrativa repetida em voz baixa, pode ser que a nova geração de designers redescubra o fio da meada da inserção de sua profissão na conturbada realidade brasileira.

Mas será que faz algum sentido olhar para trás e buscar verdades interiores em um momento em que o mundo inteiro volta-se para fora e para o futuro?

A solução para o design na periferia reside não em buscar aproximar-se do que é percebido como centro, mas, antes, em entregar-se de vez para o que ele tem de mais periférico. Colocado de maneira mais concreta, isso não está tão distante da posição preconizada pelos defensores do design social e da tecnologia intermediária, pois é nas periferias da periferia que residem os maiores desafios para o design.

De que modo os designers têm lidado, historicamente, com essa contradição entre a posição do Brasil como país periférico e o perfil cultural do design como uma atividade "de ponta", em termos tecnológicos, ou "de vanguarda", em termos estilísticos?

A resposta de cada designer tem sido diferente e seria inconsequente querer reduzir a multiplicidade de soluções criativas encontradas a uma generalização qualquer. Existem casos individuais de designers que têm conseguido realizar seus projetos dentro de padrões tecnológicos correspondentes ao exterior e totalmente inseridos em uma linguagem internacional de design. Porém, de modo amplo, pode-se dizer que o design brasileiro tem encontrado dificuldades para conciliar esse dilema, e muitos designers acabaram privilegiando apenas um dos dois lados da equação. Enquanto predominou o movimento modernista, a maioria dos designers de destaque entregou-se prioritariamente à afirmação do teor vanguardista do campo. Partindo da convicção de que a própria modernidade era o valor mais elevado, grande parte dos modernistas preocupou-se 
antes em acompanhar e reproduzir as últimas tendências internacionais do que em contemplar a relevância dessas novidades para o contexto local. Nesse sentido, os designers simplesmente acompanharam a trajetória maior do Modernismo internacional, o qual acabou vendo boa parcela de seus projetos revolucionários transformados em objeto de consumo das próprias elites que alegava combater. Mesmo no momento em que uma parte do meio de design optou por romper unilateralmente com o legado artístico das décadas anteriores, seguindo o modelo ulmiano no início da década de 1960, esse grupo manteve a sua autoconceituação de vanguarda, traduzindo as aspirações do plano artístico para o tecnológico, mas persistindo no sonho de modernidade a qualquer preço.

A identidade do Brasil não é uma identidade forte, mas, ao contrário é uma identidade frágil e, portanto, mutável, cambiante, misteriosa, e justamente por isso ela sobrevive aos choques decorrentes das profundas transformações econômicas e sociais produzidas por sua história. Entretanto, nas palavras de Ono (2006):

Diante dos imperativos de um universo cultural plural e repleto de contradições, como o do Brasil, as tentativas de definição de uma identidade de design "nacional" resultam, muitas vezes, na "invenção de tradições", na folclorização de artefatos e na materialização de esteriótipos de algumas das características culturais de seu povo, como se pode observar, por exemplo, na "tradição do carnaval" e em artefatos folclorizados, como o "orelhão em forma de berimbau" da cidade de Salvador. As funções simbólicas, de uso e técnicas dos produtos nem sempre são traduzidas adequadamente em casos como esses, quando, em muitos casos, prioriza-se o marketing e o comércio turístico.

Partindo da premissa de uma radical mudança no panorama mundial ocorrida a partir dos anos 1980, e de maneira mais acentuada após os anos 1990, analisa-se a rápida e radical transformação produtiva, tecnológica e social, que deu origem a outros paradigmas produtivos e mercadológicos, bem como a novas perspectivas 
para a disciplina do design. Este, hoje, não mais se manifesta por meio de uma rigidez metodológica, nem de um estilo único predefinido, mas, ao contrário, como um constante vetor dentro de nossa eterna mutação sociocultural.

Destacam-se os efeitos, para o design brasileiro, da passagem do modelo moderno predominante ao modelo de segunda modernidade. Essa nova realidade reabre o debate sobre a real condição do moderno como representante de uma nova ordem mundial, cujo tecido não demonstra mais ser composto por uma estrutura uniforme e equilibrada, como se via no modelo adotado anteriormente pelo design no Brasil. Essa nova condição, consequentemente, distancia o design local de um modelo narrativo linear e tende para a diversidade, para o múltiplo e plural, antecipando a multiculturalidade étnica e estética de um possível mundo global. É justamente neste ponto que inicia a principal hipótese de coligação entre o cenário em formação e o teorema design brasileiro em estudo.

Essa realidade que se delineia, como parte do percurso de uma nova realidade mundial, traz novas esperanças para o design local, pois esse fenômeno coloca em evidência os valores múltiplos, sincréticos, híbridos e plurais que sempre estiveram presentes na base formativa da experiência mestiça brasileira.

Outra questão que se apresenta é: como o designer brasileiro pode ajudar as questões sociais nacionais, entendendo o design social como o fim da dissociação entre "design de mercado" e cidadania?

É sabido que a separação entre design e artesanato existe desde o início da prática e do ensino do design no Brasil, gerando uma busca pelo estilo internacional moderno como fonte externa de inspiração. Mas também é inegável no panorama nacional atual a relação entre design e artesanato visando a melhoria na qualidade de vida do cidadão. Isto é, o design para um mundo solidário, com a inclusão dessa população no mercado por meio da valorização de sua produção e, paralelamente, com seu potencial transformado em resgate da autoestima. Nesse sentido, cabe salientar o trabalho dos irmãos Campana, que levam para o mundo industrial o manual do artesanal. 




Figura 26 - Criação dos irmãos Campana, inspirada na poltrona Corallo, para a coleção Verão 2009 da Melissa.

Entretanto, o que se configura na atualidade é a multidirecionalidade dos fluxos culturais, resultado da globalização, em que podese observar a presença de outras tendências, outras referências além da Europa e dos Estados Unidos.

Paralelamente, como reflexo das tranformações político-sociais, o impeachment do presidente Fernado Collor devolveu aos brasileiros o "orgulho de ser brasileiro" e foi também usado pelas empresas e pelo PBD, com a criação da Marca Brasil, o espelho onde nós nos reconhecemos e queremos ser reconhecidos. Ou seja, dentro da lógica Global fashion, local tradiction, que, em resumo, quer dizer que um bom design, para ser global, antes tem de ser local. Em outras palavras, mais do que ser um bom design, o que importa é a "Marca País”. Mais que um produto, o seu significado, que deve pertencer a uma bandeira.

Até o final dos anos 1980, era bastante improvável encontrar produtos brasileiros nos principais centros comerciais da Europa e dos Estados Unidos. Tampouco se imaginaria que, vinte anos depois, italianos e americanos comprariam a peso de ouro móveis assinados pelos irmãos Campana, ou que os adeptos dos automóveis compactos curvariam-se aos encantos do Fox, um carro totalmente 
desenvolvido nos pátios da Volkswagen em São Bernardo do Campo, na Grande São Paulo.

E ainda, como elemento importante na formação deste quadro, não se pode esquecer da abertura do mercado nacional para produtos estrangeiros na década de 1990, obrigando os empresários a não copiar formas internacionais. A falta de concorrência dos produtos brasileiros com similares estrangeiros, durante muitas décadas, levou a indústria nacional a permanecer em uma situação confortável, até que a política econômica abrisse nosso mercado aos produtos importados. A saída encontrada pelas empresas brasileiras para enfrentar os produtos importados nos anos 1990 e tentar ampliar as divisas do país por meio da exportação foi investir em design. O objetivo era desenvolver produtos funcionais, de qualidade, em condições de competir com os concorrentes estrangeiros. Um exercício difícil, já que a cultura da cópia era o meio mais barato para se montar uma linha de produtos.

Com isso, o design passou a receber atenção especial dos empresários brasileiros, pois estes não conseguiam mais concorrer com igualdade de condições com os produtos estrangeiros disponibilizados no mercado. Era notória a diferença de satisfação que os consumidores experimentavam quanto à estética, à qualidade, aos baixos preços e à durabilidade.

Começava a se desenhar no Brasil um cenário que a cada dia é confirmado e apontado como tendência: o design, profissão que surgiu no fim do século XIX, com o processo de industrialização da Europa e dos Estados Unidos, é hoje um dos maiores diferenciais de competitividade industrial.

A fabricação de objetos de design requer investimentos, e ainda são poucas as empresas que pensam em uma gestão do design. Assim, o grande desafio do profissional é conscientizar o empresário de que um objeto sem design é um produto de risco. O design agrega valor ao produto em termos de estética, ergonomia, conforto e funcionalidade, além de ser um elemento muito importante na racionalização da produção. O designer, no contexto do mercado globalizado, deve estar apto a atuar com visão estratégica, contribuindo 
para aumentar a competitividade do produto brasileiro. A indústria brasileira, por exemplo, busca ampliar seu mercado interno e conquistar o externo. Para que ela possa se colocar em condições de disputar o mercado de consumo com indústrias estrangeiras, é imprescindível que focalize sua atenção na racionalização da produção e na consequente redução do custo de seus produtos. Cabe ao designer mostrar a importância e as possibilidades de se fazer do design uma ferramenta de gestão empresarial e de inovação, atuando em todas as etapas do processo, e não só no final.

Recentemente, o Sebrae selecionou o design como uma das áreas prioritárias para sua atuação no universo das micro e pequenas empresas, elaborando um programa que visa elevar a competitividade destas no mercado nacional, contribuindo também para promover sua participação nas exportações por meio da utilização do design como elemento de agregação de valor a produtos e serviços.

Vencendo a batalha da inovação e da diferenciação, o design cria uma personalidade capaz de conquistar a fidelidade do consumidor. Nas palavras de Vieira (2004): ${ }^{1}$

É preciso apenas que o empresário brasileiro, em sua grande maioria, visualize que está diante de tempos novos. Tempos de abertura, onde o consumidor se mostra mais exigente, reivindicando bens e serviços que atendam a seus anseios. O design se encaixa muito bem nessa questão, atuando como fator de competitividade. Design é o segredo. E os empresários que não estiverem sensíveis para estas questões devem ficar atentos em momento futuro, porque se eles não se modernizarem, se não procurarem processos mais adequados, ficarão no passado, não conseguirão competir com seus concorrentes.

É nesse cenário que o design no Brasil se estabelece, ganha espaço e desenvolve-se, justamente no conflito e na tensão entre a realidade local e as referências provenientes do exterior, entre os ideais

1 Eduardo Vieira, Diretor de Criação da Tribo 12, Tecnologia da Informação, Rio de Janeiro. 
dos protagonistas oriundos dos países mais industrializados e as aspirações dos atores protagonistas locais. Estes últimos, dotados de grande sentimento de determinação, apostavam justamente no futuro industrial do Brasil e na indispensável presença da atividade de design como partícipe no desenvolvimento da cultura material dentro do processo de modernidade nacional. É interessante notar que o design é instituído e entendido como um projeto de futuro, exatamente como se via e se vê o próprio Brasil: como o país do futuro.

No Brasil, pelo menos, afirma Cardoso (2004), não há base empírica para se falar em recuo ou encolhimento do campo. Ao contrário, os últimos dez anos têm testemunhado uma nítida diversificação das possibilidades de trabalho para o designer e uma multiplicação correspondente de instâncias de atuação profissional. O design brasileiro passou, na década de 1990, de uma atividade restrita tradicionalmente a meia dúzia de praticantes bem-sucedidos, para um patamar inédito de produção sobre um leque amplo de frentes de trabalho. Diferentemente de toda a longa trajetória histórica, seria muito difícil resumir o design brasileiro da última década a dois ou três nomes de destaque. $\mathrm{O}$ forte crescimento do campo desde o final da década de 1980 trouxe a tão esperada pulverização: muitos profissionais atuando de forma discreta, e até mesmo anônima, em áreas tão diversas quanto o design de produtos de cama, mesa e banho ou o design de fontes digitais.

Isso não quer dizer que estejamos vivendo no melhor dos mundos possíveis para o designer e muito menos que o design brasileiro não tenha mais para onde crescer. O mercado de trabalho flexível e fragmentado que se apresenta ao profissional iniciante é, sem dúvida, um lugar assustador, com muitas dificuldades e praticamente nenhuma garantia, mesmo para os mais talentosos. Deve-se dizer, todavia, que também se trata de um mercado cheio de possibilidades, aberto por definição para o novo e o diferente. Ao contrário da situação relativamente estável de trinta anos atrás, quando os únicos clientes em potencial para o designer eram grandes empresas estatais ou multinacionais, existe hoje um mosaico de pequenas e microempresas, associações e sociedades comunitárias, organiza- 
ções não governamentais, fundações e outras entidades que nunca estiveram tão ativas no cenário econômico nacional. Alguns designers também começam a optar por se envolver diretamente com o comércio ou outras atividades empresariais, e, sem dúvida, há muito espaço para a ampliação de nichos mercadológicos existentes e/ou para a abertura de novos. A lição que se depreende das trajetórias dos designers brasileiros que mais se destacaram nos últimos anos é que não existe uma única fórmula válida para todos: cada designer tem de encontrar seu caminho e construir sua própria identidade profissional.

Campo é o que não falta. Se existe um país carente de sistemas de organização coletiva, de clareza na difusão de informações, de planejamento estratégico da produção, de soluções criativas para problemas aparentemente insuperáveis - enfim, de projeto - esse país é o Brasil.

Como atividade posicionada historicamente nas fronteiras entre a ideia e o objeto, o geral e o específico, a intuição e a razão, a arte e a ciência, a cultura e a tecnologia, o ambiente e o usuário, o design tem tudo para realizar uma contribuição importante para a construção de um país e um mundo melhores.

Por outro lado, o design no Brasil pode não ser categoricamente elitista, mas ainda compete com a "falsa imagem" de status e acessibilidade elitista. Isso ocorre, em geral, pela desinformação de empresas e consumidores sobre o que é o design, o que ele pode acarretar. Poucos entendem como o design analisa os "aspectos funcionais, formais, ergonômicos, sociais, produtivos e tecnológicos para desenvolver produtos destinados à produção em série" (Moraes, 1997, p.86).

Para Bonsiepe (1997), o design fugiu muito da ideia de solução inteligente de problemas e tem se tornado cada vez mais objeto de butique, peças meramente formais, artefatos de moda e rapidamente obsoletos. Talvez motivado pelas facilidades proporcionadas pelo mercado cambiável, o mundo vive hoje como uma "feira" de produtos. Os baixos custos de fabricação e comercialização de produtos de países como a China têm tornado ainda mais difícil 
para o Brasil o investimento em design, uma vez que a importação de componentes, peças e até mesmo produtos inteiros é a principal causa da "desvalorização" do design brasileiro. Para as empresas, é muito mais rentável investir em produtos comercializados no mundo inteiro - e que, portanto, tornaram-se aceitáveis -, mas muitas vezes de qualidade e materiais duvidosos, do que investir em projetos nacionais com maior qualidade de acamamento e desenvolvimento projetual.

A compreensão do design brasileiro é dificultada pela aquisição de diferentes vertentes, modelos e principalmente do entendimento da realidade do país. Quando analisam-se designers como os Campana e Guto Índio da Costa, por exemplo, é claramente percebido como o Brasil abriga um "coquetel" de abordagens e definições.

Os Campana (Figura 27) estão atrelados a uma inspiração pela diversão, por apelos criativos, pelas fugas das funções premeditadas de alguns objetos. Lembram em muito a linha seguida pelo design italiano, o design for fun. Eles veem no design uma maneira de expressão artística e tratam seus produtos como tal.
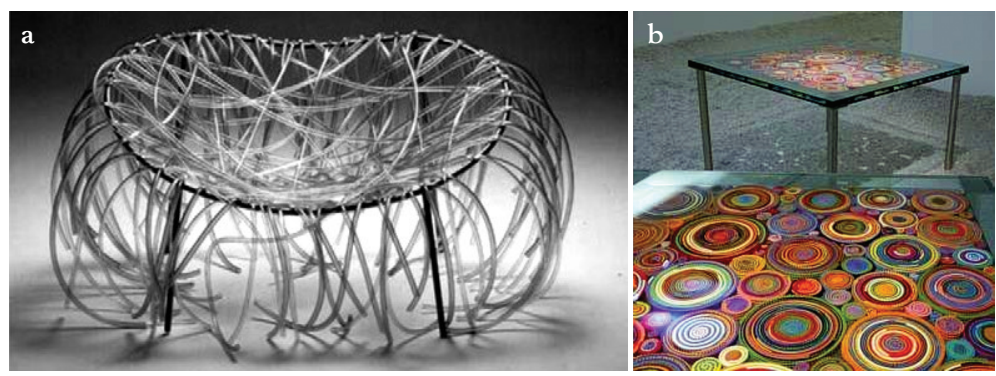

Figura 27 - Cadeira Anêmona (2000) (a) e mesa Sushi (2002) (b). Presentes em várias exposições internacionais e com peças em importantes coleções (como o MoMa, de Nova Iorque, e a Pinakotheke der Moderne, em Munique), os Campana fazem parte do starsystem do design mundial.

Já Guto Índio da Costa (Figuras 28 e 29) transmite em suas criações a linha funcionalista e simplificada do design alemão com as visualizações de mercado atreladas ao design americano. 

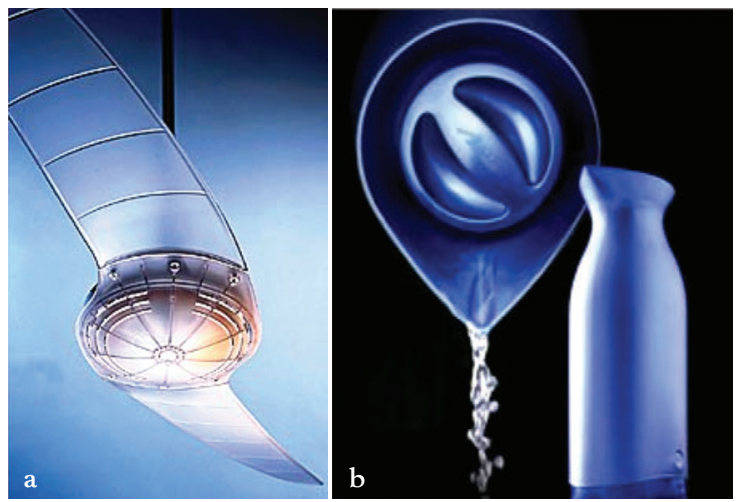

Figura 28 - Um de seus projetos mais conhecidos, o ventilador Spirit (1984) (a), premiado no Brasil e no IF Design Awards, em Hannover, em 2002, transformou por completo uma pequena fábrica de cartuchos para videocassete no Rio de Janeiro e tornou-se, assim como a garrafa térmica Alladin Futura (1996) (b), exemplo de produto de desenho elegante e preço acessível para o mercado interno brasileiro (Leon, 2005).
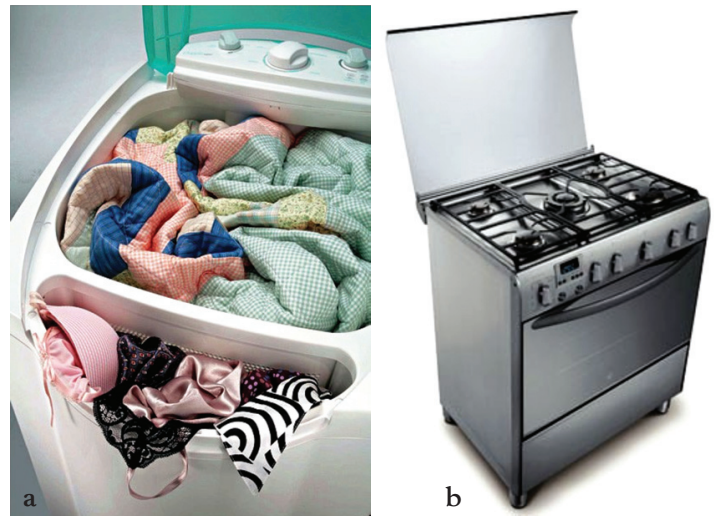

Figura 29 - Lavadora semiautomática Duppla, da Arno (a). Design de Guto Índio da Costa, Felippe Bicudo, Ado Azevedo, Manuela Vilaseca, André Lobo e Gustavo Russi. Menção Honrosa na categoria eletroeletrônicos no $21^{\circ}$ Prêmio Design do Museu da Casa Brasileira, ocorrido em 2007. Fogão GE Profile Digital (b). Design de Índio da Costa Design (Marco Antonio M. Fonseca, Guto Índio da Costa, Eduardo Azevedo e Augusto Seibel). $2^{\circ}$ lugar na categoria eletroeletrônicos no $17^{\circ}$ Prêmio Design do Museu da Casa Brasileira, em 2003. 
Talvez Guto Índio da Costa e os Campana consigam impor um diferencial brasileiro em suas criações, afinal, não existe ainda realmente uma linha de pensamento que defina o design brasileiro como ele se coloca. É mais visível que o país se mostra ao mundo com muitos talentos criativos, com consciência do mercado global, mas também não podemos desprezar o fato de que o Brasil ainda carece de muitas intervenções e muitas soluções.

O design nacional atinge vários modelos e vertentes e mostra-se diferente até mesmo na maneira pessoal de enxergar o design. Os Campana alegam um design mais pessoal, com fuga da indústria. Já Guto Índio da Costa mostra-se como um projetista da produção seriada, aderindo às formalidades metodológicas de projeto.

Para alguns, o principal caráter de design de um país reside no fato de sua acessibilidade às massas, de como ele é levado à vida cotidiana da população, e não perece nos atributos estéticos ligados ao regionalismo de cada país. Pedro Luiz Pereira, designer e professor da ESDI, atenta para esse reconhecimento do caráter nacional do design.

Temos discussões terríveis no Brasil sobre o caráter brasileiro, o caráter nacional, o que é uma bobagem. O caráter nacional não se dá pelo fato de esta cadeira aqui ter ou não elementos formais adequados à nossa cultura. O que faz diferença é: "esta cadeira é acessível à maioria dos brasileiros ou não?”. Do momento em que ela for acessível e estiver resolvendo os problemas dos brasileiros, será um design brasileiro muito bom. Enquanto for uma coisa que só pode ser adquirida por um grupo restrito de pessoas, tanto faz ela estar aqui como na Indonésia, na Suécia, nos Estados Unidos, em qualquer lugar, ela será simplesmente um objeto. [...] Este país não se democratizou. O design como foi pensado, como elemento de democratização, talvez não seja mais um caminho, mas que design então será que pode colaborar para isso? Acho que esse é um bom motivo para se pensar. (Pereira, 2007)

Para Pereira (idem), a melhor maneira de evolução de um país é enxergar seus reais problemas. Quando tomada como exemplo 
no discurso de Pereira, a Suécia não esteve muito longe do Brasil pela pobreza e elitização do design. Para ele, a Suécia evoluiu não só como país, mas como exemplo de instrumentária de design, quando percebeu que o design para os ricos não aquecia a economia, mas sim a criação para as classes emergentes que sustentavam o país. Pode-se dizer que desta visão surgiram muitos casos de sucesso, como a empresa Ikea, que soube aliar a qualidade de projeto a preços acessíveis a boa parte da população. Faz sentido notar que, apesar de criar para as massas, a empresa também soube manter as características mais burguesas em alguns de seus produtos, satisfazendo, assim, compradores das diferentes classes sociais.

O que se pode reparar no Brasil é que produtos destinados a um mercado de menor poder aquisitivo, em geral, não apresentam a preocupação necessária com as qualidades formais do objeto, podem ser considerados meras cópias de produtos de alto valor comercial e que, de certa maneira, contribuem para a afirmação de que o Brasil trabalha com um design elitista. É claro que isso não pode ser tomado como um pensamento generalizado, pois existem muitas tentativas no país de tornar o design mais acessível, ou mais verdadeiro, do ponto de vista nacional.
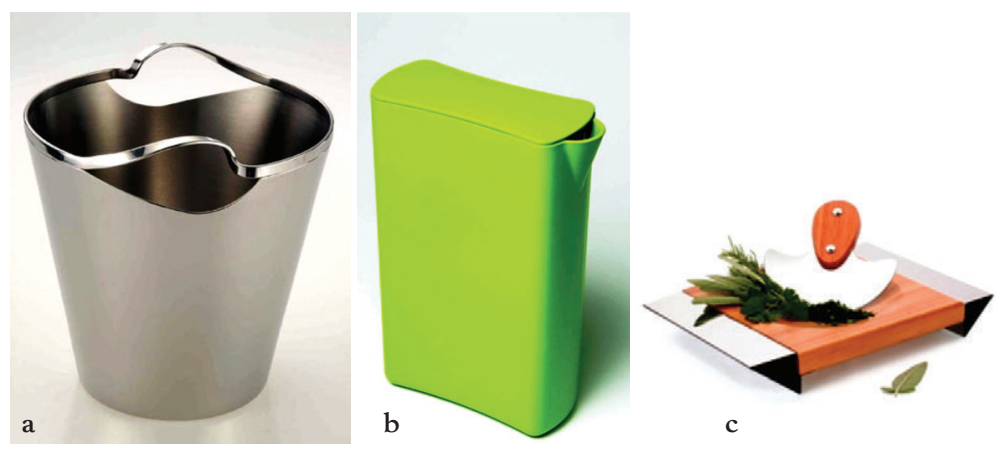

Figura 30 - Balde para garrafa Ritz (a), de Rubens Simões e Cléber Luis da Ré. $1^{\circ}$ lugar no Prêmio Design do Museu da Casa Brasileira em 2006. Jarra Due (b), de Valter Bahcivanji. Menção Honrosa no Prêmio Design do Museu da Casa Brasileira, em 2006. Conjunto para picar temperos (c), de Gétri Bodini. Premiado no IX Prêmio House \& Gifts de Design, em 2008. 
O Brasil ainda está desencontrado com seu culturalismo plural, sua capacidade produtiva e com a verdadeira capacidade de atuação no mercado global, uma vez que ainda faz muito uso de soluções estrangeiras para suplantar a incapacidade nacional na fabricação de produtos competitivos. O país precisa, acima de tudo, observar suas qualidades de centro e periferia e adequar o design a elas. Países como a Alemanha, os Estados Unidos e a Finlândia conseguiram formar uma base estrutural para o entendimento da função e da importância do design na produção de bens de consumo. De maneira geral, o Brasil não é carente de profissionais ou de bons projetos. A questão-problema talvez não seja descobrir o design brasileiro, mas como o design vem se inserindo no Brasil.
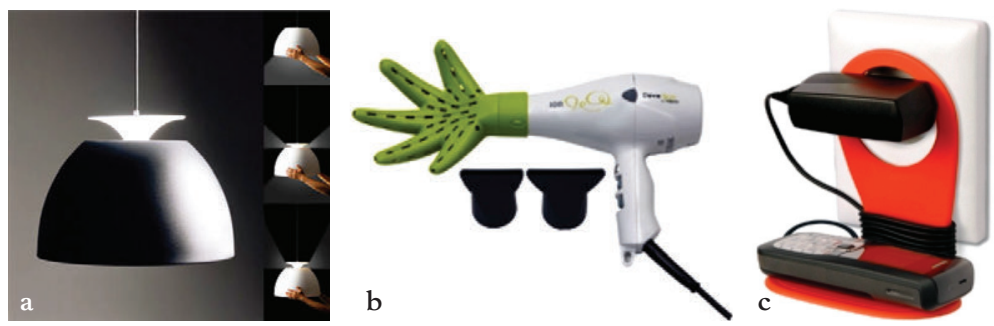

Figura 31 - Luminária Bossa (a), de Fernando Prado para Lumini. Prêmio Idea/Brasil 2008, vinculado ao norte-americano International Design Excellence Award. Secador de cabelos com difusor (b), de Sidney Rufca, Gustavo M. de Camargo, Alexandre Scartezini, Renata Pujol, Guilherme L. Gomes, Tanna Gomide, Felipe Uzum, Rafael M. Carneiro e Daniel Yaginuma. Premiado no IX Prêmio House \& Gifts de Design, em 2008. Drinn (c), de Cláudio Brandão. Facilita e organiza a recarga de pequenos aparelhos eletrônicos como telefones celulares, iPods, máquinas fotográficas digitais ou aparelhos de MP3. Premiado no IX Prêmio House \& Gifts de Design, em 2008.

O mais evidente ao analisar o design brasileiro é que ainda existem poucas publicações literárias que possam ser consultadas. As informações, em geral, são coletadas por meio de poucos autores, e cada autor possui uma visão peculiar a respeito dos alcances do design brasileiro. Mas, ainda assim, todos compartilham da ideia de que o Brasil já não carece mais de tantas influências estrangei- 
ras e que pode encontrar em seus profissionais a motivação que o design nacional precisa para relacionar-se de maneira correta com sua população. Nas publicações brasileiras sobre design, principalmente desde 2000, pode-se notar um significativo contingente de pesquisas qualitativas e metodologias apropriadas aos processos de produção como forma de difundir essa produção, de maneira competitiva, em mercados nacionais e/ou internacionais.

Em termos internacionais, o design brasileiro tem tido premiação recorde, resultado dos esforços de profissionais e empresas que passaram a investir na gestão do design. Entretanto, poucas mostras de design se mantêm no calendário nacional de modo regular. A mais importante em funcionamento é a Mostra do Prêmio do Museu da Casa Brasileira (Figura 32).
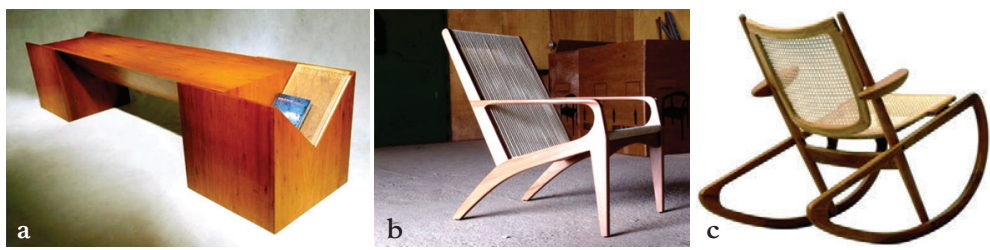

Figura 32 - Banco Bandeirola (a), de Ivan Rezende. $1^{\circ}$ lugar na categoria mobiliário no Prêmio Design do Museu da Casa Brasileira, em 2004. Poltrona Gisele (b), de Aristeu Pires. $1^{\circ}$ lugar na categoria mobiliário no Prêmio Design do Museu da Casa Brasileira, em 2007. Cadeira de balanço Verão (c), de Fernando Mendes de Almeida e Roberto Hirth. Menção Honrosa na categoria mobiliário no Prêmio Design do Museu da Casa Brasileira, em 2007.

A inserção do design nas indústrias brasileiras é de grande importância para os profissionais que atuam nesse setor, para as indústrias, que gradativamente vêm fazendo uso cada vez maior dessa ferramenta, e para o país, que pode fazer do design um diferencial que tornará os produtos brasileiros mais competitivos internacionalmente, contrariamente à opinião de muitos empresários regionais que ainda acreditam ser o design útil apenas às empresas que atendem aos segmentos de alto poder aquisitivo. 
A crescente popularização do design nacional também pode ser constatada por meio da pesquisa de novos produtos e de uma aproximação com as tecnologias industriais, peças que fazem a diferença real para o conforto e o bem-estar do consumidor, possibilitando o aprofundamento do conhecimento e de pensar um produto adequado em relação à matéria-prima escolhida. Tecnologias avançadas, matérias-primas sofisticadas e apuro na qualidade dos produtos têm pautado a produção da indústria brasileira, permitindo que esta, nos últimos anos, desenvolvesse muito sua capacidade produtiva e aumentasse significativamente a qualidade de seus produtos.

Nossa sociedade está em permanente transformação, exigindo que empresas e profissionais estejam constantemente atentos para as mudanças sociais, tecnológicas e políticas. As empresas, que primeiro competiam por preço, passaram a competir por qualidade, migrando para a competição por design e marca. É preciso, portanto, que empresas e designers tenham consciência dessas mudanças e busquem juntos um conceito único para o design.

A constante diferença entre as expectativas dos empresários e as dos designers quanto ao desenvolvimento de um determinado produto ou quanto aos resultados de uma consultoria deve-se em parte à crença, por parte dos empresários, de que dentro do segmento popular não cabe o trabalho de design. Isto reflete o desconhecimento por parte dos empresários de como se dá o trabalho do designer e de que forma o design pode ser incorporado ao produto e ao processo produtivo. A priori, acredita-se que isto se deve ao desconhecimento que a maioria dos empresários tem sobre o que é o design e como este pode contribuir para a melhoria de seus produtos e de seu sistema produtivo. Por outro lado, esse desconhecimento também pode ser creditado a uma falha de comunicação dos próprios designers, que muitas vezes não têm nem eles próprios uma visão muito clara do que seja a profissão ou de como agir diante de um problema real, de uma indústria real.

O aumento da importância da questão ecológica em diversos segmentos do mercado vem forçando o desenvolvimento de pro- 
dutos ecologicamente corretos. Novas tecnologias, utilizadas pelos concorrentes, também podem ser o fator de declínio de produtos antes largamente vendidos, daí a importância de estar sempre à frente nas inovações para permanecer no mercado. A pressão da concorrência, a diferenciação do produto por meio do bom design e a transformação no estilo de vida dos usuários são alguns fatores que despertam o empresário para a gestão de design. É preciso estar consciente de que o investimento em pesquisa de mercado e em pesquisa tecnológica aplicada é de grande importância, podendo gerar a flexibilização da produção e a administração para acompanhar as mudanças da competição e do gosto dos clientes.

O design como atividade interdisciplinar terá mais chances de sucesso em empresas em que a integração organizacional prevaleça. Do contrário, o design terá grandes barreiras em uma empresa com grande estrutura burocrática, com uma minuciosa divisão de trabalho e com elevada centralização das decisões acumuladas em sua cúpula.

Seria errôneo afirmar que uma empresa sem designers não faz design, do mesmo modo que uma empresa sem vendedores não vende. A questão não é essa, e sim a de que em um mundo globalizado e competitivo não basta vender, é preciso vender mais e melhor. No caso dos produtos, é preciso uma atenção especial do ponto de vista empresarial de modo a conseguir produtos melhores, adequados ao processo produtivo e ao mercado a que se destinam. Desta forma, os designers devem atuar não somente nos segmentos altos, acrescentado valor e custos ao produto, mas também quando as limitações de custo e preço são grandes. É muito frequente a ideia de que o design incrementa custo ao produto. Parte dos designers também acredita que a qualidade está acima de outras considerações. Do ponto de vista da empresa, um produto não é bom ou mau por si só, mas sim em função do segmento de mercado a que se dirige e em relação a seus concorrentes.

Talvez por características inerentes à sua colonização e industrialização tardia o país teve dificuldades em atingir os patamares das escolas de outros países tomados como modelo. É inegável que 
as diferenciações culturais e as percepções populacionais a respeito de seus ideais e direitos é que motivaram as conquistas e interesses pelo desenvolvimento de cada país. De fato não possuímos a tecnologia americana e a alemã, ou um mercado preparado para as produções italianas, e é difícil que se atinja tal fato com facilidade, mas vale lembrar que todos esses países um dia também estiveram em situação parecida com a do Brasil e não objetaram em investir em criações próprias e em tecnologia.

A maior crítica fica para que o design também esteja presente nas massas, no sentido de atingir a todos, sem diferenciações de classe, com a qualidade e o respeito que lhes é digno. O país pode ir além de produtos manufaturados na China ou de artigos luxuosos. O que se espera do design nacional é qualidade projetual, seja ela funcionalista ou irreverente. O Brasil pode ser o país com um design sincero de qualidade, pois tem capacidade para projetos bem executados em mobiliários populares encontrados nos famosos magazines, assim como para o caminho social na solução de problemas encontrados nas áreas da saúde, transportes, moradia e urbanização. Toda essa pluralidade nacional talvez seja muito mais correta do que um sistema único para um país de culturas diversas, basta que para isso o design brasileiro una-se em princípios, não em modelos metodológicos. 



\section{6 \\ O ENSINO de DESIGN No BRASIL}

O início da prática do design e de seu ensino no Brasil ocorreram, segundo Couto (2008), de maneira empírica, da mesma forma que nos primórdios da Bauhaus, quando grandes nomes da Arquitetura e das Artes Plásticas em geral reuniram-se com a intenção de dar uma forma e uma linguagem contemporânea à produção industrial.

Simbolicamente, opta-se pela afirmação de que o ensino de design no Brasil tem como marco inicial a fundação da Esdi, ${ }^{1}$ que, tendo em vista suas origens, remonta à Escola de Ulm (Gestalt) e, antes dela, à Bauhaus. Possivelmente por isso, o principal guia de nossos designers seja o Funcionalismo, característica marcante das escolas alemãs, pois mesmo a iniciativa na década de 1950, de Lina Bo Bardi e Giancarlo Pallanti, de um curso regular de design no então Instituto de Arte Contemporânea-Museu de Arte de São Paulo IAC-MASP, apesar de ter durado apenas dois anos, também não escondia sua influência da estética racionalista da arquitetura e do design modernos.

Por outro lado, ainda segundo Couto (idem), seria pueril acreditar que o ensino de design iria surgir espontaneamente e com um modelo de ensino genuinamente brasileiro, ainda mais em meio a

1 Disponível em: <http://www.esdi.uerj.br/> Acesso em: jun. 2008. 
um período desenvolvimentista em que, para o mercado, o modelo a ser invejado deveria ser o norte-americano. Mas o currículo da Esdi já havia se transformado no paradigma para o ensino de design no Brasil. Ironicamente, a indústria brasileira de fato não estava lá muito interessada nos recém-formados profissionais nacionais e o ambiente político do final dos anos 1960 não era aconselhável para um design socialmente engajado. Paradoxalmente, dez anos depois, e em função do maior incentivo financeiro dado pelo governo às áreas tecnológicas - paralelamente aos cortes nas áreas sociais e artísticas -, gerou-se um boom de cursos de artes transformados em cursos de design às pressas, havendo então a necessidade de se repensar as questões curriculares, pois isso, por um lado, "permitu grande liberdade e originalidade aos currículos plenos dos cursos, por outro, permitiu também a criação de aberrações".

Um país de dimensões continentais como o Brasil poderia ter promovido em paralelo, durante a instituição do ensino de design na esfera local, experiências e modelos de ensinamento diferenciados, com características e ideais diversificados, como são na verdade diversas as vocações e o comportamento dos brasileiros. Os conceitos funcionalistas poderiam ter sido mantidos como referência projetual em uma escola e/ou região brasileira, outros poderiam ter adentrado a promoção de possíveis e diferentes modelos para o design local, na busca de resultados e soluções distintas e, ainda, mesmo poéticas diferenciadas.

Por outro lado, paradoxalmente, nos programas de ensino das faculdades de design do país adotou-se o modelo da tecnologia alternativa. Os novos graduados, ao deixar a faculdade e ingressar no mercado de trabalho, deparavam-se com um parque produtivo, já bastante desenvolvido, cujo modelo estava fundamentado na tecnologia produtiva ocidental. Os parques industriais locais vinham se equipando, mais e mais, com ferramentas e maquinários próprios da produção industrial de perfil convencional, nos moldes da modernização mundial.

Em uma nova etapa do ensino de design, posterior às experiências com tecnologia alternativa, era prática comum por parte de muitas escolas a inserção de temas projetuais que estivessem de 
acordo com a realidade e o contexto do parque industrial instalado nessas regiões. Tal prática, apesar de nitidamente bem-intencionada, acabava por não corresponder à realidade, contradizendo-a muitas vezes. Segundo Moraes (1999), a rapidez de referências e informações recebidas pelos empreendedores e consumidores do Brasil e da América Latina era, antes de tudo, uma forte barreira para a prática e o sucesso desse plano de ensino.

A constante semelhança entre os resultados projetuais obtidos pelos alunos - por meio da solicitação de temas muitas vezes repetitivos - gerava um nivelamento mediano da qualidade dos projetos. Não obstante, os métodos projetuais permaneciam com características extremamente funcionalistas, em detrimento de outros atributos importantes, como os valores reflexivos e culturais inerentes ao processo da prática em design. Repassava-se aos alunos um conceito de design cuja "função básica" era projetar produtos para produção em série pelas indústrias. Dessa forma, ensinava-se aos estudantes a importância de saber considerar e aplicar os fatores técnicos, sociais, ergonômicos, estético-formais e produtivos que, uma vez bem dosados, lhes mostrariam um caminho mais lógico e seguro para o sucesso de seu projeto e para o desenvolvimento de novos produtos.

As diversas escolas existentes vinham se apoiando nesses valores e métodos projetuais como verdadeiros dogmas. Diante desse quadro, percebe-se que os estudantes eram capazes, ao final da formação escolar, de projetar um produto, ou seja, eram capazes de cumprir todas as etapas descritas nos métodos de "projetação" existentes no programa de ensino escolar e de seguir as metodologias projetuais determinadas pelos seus professores.

Mas estariam realmente fazendo design?

$\mathrm{Na}$ verdade, o que vinha acontecendo, salvo raras exceções, era a simples utilização e aplicação quase automáticas dos diversos fatores necessários a um projeto.

Os professores, por sua vez, segundo Moraes (idem), trazem para a sala de aula cases de profissionais atuantes de sucesso e com mais experiência de trabalho, utilizando-os como referência aos estudantes. Isto se reflete na limitação do ensino de design, em vez de possibilitar a diversificação e a abrangência necessárias. 
A ansiedade criada junto aos alunos pela aplicação dessas referências acaba por inibir seu processo de formação. Além disso, referências personalizadas junto ao ensino de design podem proporcionar um sentimento de inferioridade por parte de muitos dos recémformados e iniciantes ao terem seus projetos comparados com os dos já estabelecidos e experientes profissionais atuantes no mercado.

Moraes (idem) entende que durante um processo de ensino de design, o aspecto mais importante não seria aquele de fácil identificação - como o aspecto estético - nem de fácil aplicação - como os fatores técnicos e ergonômicos -, e sim a síntese da cultura projetual por meio dos valores reflexivos, culturais, críticos e analíticos durante o processo de "projetação".

Estariam os alunos preparados para situar seus produtos quanto às tipologias de uso e às tipologias formais? Seriam eles capazes de situar seus produtos quanto às referências históricas e culturais? E quanto aos aspectos reflexivos, comportamentais e humanos?

Os estudantes de design devem habituar-se a usar o raciocínio reflexivo e analítico durante as fases de desenvolvimento de um projeto. E ainda, devem ter senso crítico sobre as reais possibilidades de aplicação de seu produto junto ao mercado consumidor e junto ao usuário, além de habituar-se à aplicação de enfoques humanísticos e de valores culturais como fatores de diferenciação e como geração de novas alternativas projetuais. Caso isto não ocorra, correm o sério risco de se tornarem reféns dos fatores objetivos da projetação.

É tarefa dos cursos de design, por meio de suas disciplinas projetuais, fazer com que os alunos, utilizando-se de temas prévia e estrategicamente estabelecidos, pratiquem uma forma de projetação em que prevaleçam enfoques subjetivos e teóricos como elementos diferenciadores de projeto. Isso deve ocorrer até que essa prática torne-se um fator natural e intrínseco ao seu processo e método projetuais. Deste modo, está-se preparando não somente um dosador de diversos fatores e aspectos projetuais, mas um pensador para novas e diferenciadas soluções.

$\mathrm{O}$ aluno deve ser conduzido a abstrair-se momentaneamente do produto que vem a ser o escopo de seu projeto. Ele tem de apro- 
ximar-se do contexto e da situação que envolvem o tema projetual proposto. Por exemplo, não se deve pensar em uma cadeira, mas no ato de sentar; não se faz necessário pensar no copo, mas no ato de beber; não se deve pensar em uma vitrine, mas no ato de expor e mostrar algum objeto, e assim sucessivamente.

Por sua vez, um projeto assim direcionado tem maior possibilidade de apresentar soluções mais inovadoras, diferenciadas e, às vezes, até quem sabe inusitadas. Caso contrário, surgirão apenas outras cadeiras, copos e vitrinas que poderão eventualmente ser mais belos, mais funcionais ou mais atraentes, como os resultados que vemos serem obtidos junto aos métodos projetuais convencionais empregados na atualidade.

Desse modo, o estudante não receberá informações sobre o tema específico de projeto, e sim sobre o tema genérico. Contudo, esse tema genérico deve ser exposto pelo professor de modo a possibilitar o surgimento de diversas propostas projetuais, buscando incentivar uma variação de temas específicos dentro daquele tema genérico fornecido, cabendo ao estudante programar a escolha do tema específico, de seu trabalho e do desenvolvimento projetual.

Entendendo que projetar não é impor uma solução autoral e autoritária, mas dividir com o interlocutor a responsabilidade da troca e dar uma contribuição espontânea, que sensibilize e conquiste pela via social e estética, o objetivo das disciplinas projetuais do curso de Design de Produto da FAAC - Faculdade de Arquitetura, Artes e Comunicação da Unesp, campus de Bauru, é introduzir o aluno nos problemas espaciais, formais e estéticos do projeto, relacionando o design com a produção industrial, ou seja, compreendendo a interdependência de atuação profissional entre o processo de criação (projeto) e o processo de execução (indústria).

Para tanto, e para que se possam desenvolver processos que permitam criar e recriar repertórios, por meio de uma visão crítica da realidade, o aluno desenvolve projetos de modo que exercite sua criatividade e visão espacial, desenvolvendo a metodologia relacionada ao desenho do objeto paralelamente a aulas teórico-expositivas em que o usuário não é visto apenas como um ser cujas necessidades 
práticas precisam ser satisfeitas, alienando-o de questões socioculturais e eventualmente até econômicas que permeiam o imaginário do universo dos objetos cotidianos.

Alguns dos resultados podem ser observados nas figuras 33 a 37.

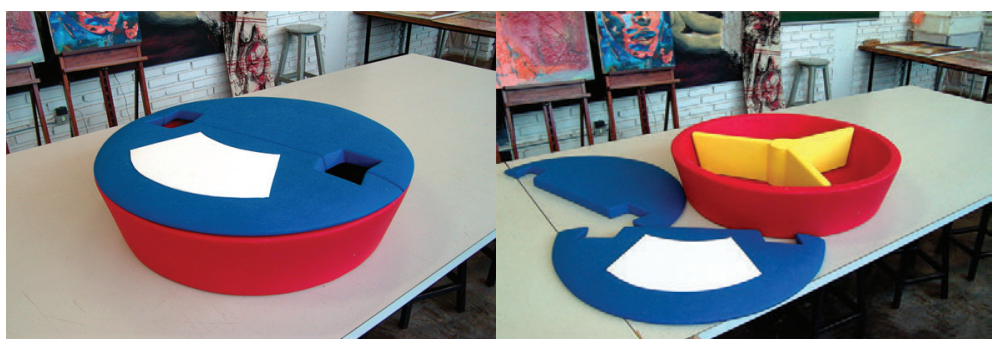

Figura 33 - Uma caixa de polietileno utilizável tanto como mobiliário como para brinquedo. Menção Honrosa na Categoria Estudante no Concurso Abiplast Design 2005, Associação Brasileira da Indústria de Plástico. Alunos: Mariana Menin, Laura Schaer Dahrouj e Fernando Feldberg.
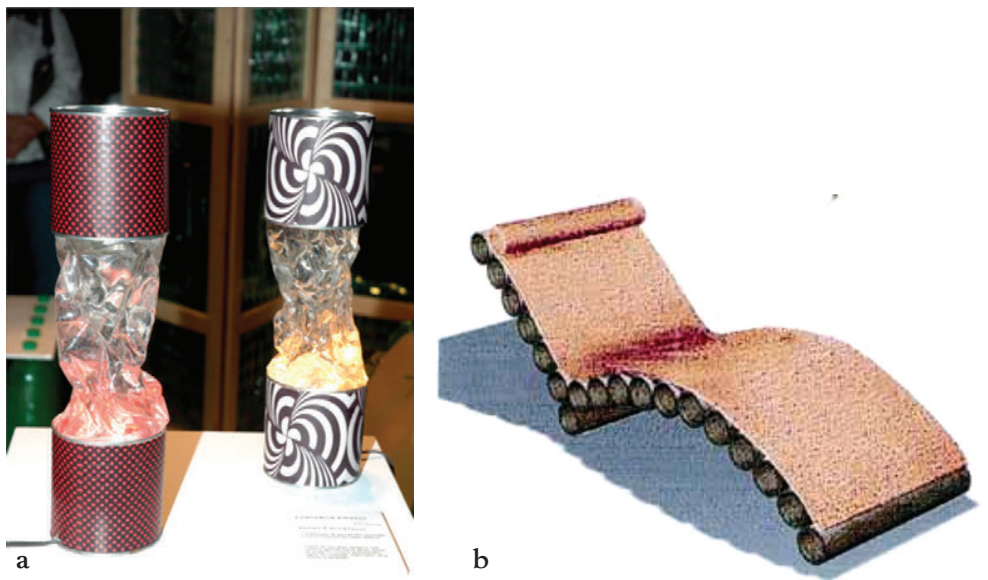

Figura 34 - I Concurso OndaAzul Design Recult 2005, Fundação Onda Azul, Rio de Janeiro, RJ. Projeto desenvolvido na favela Vigário Geral, zona sul do Rio, onde são fabricados móveis com garrafas PET. Jonas Carnelossi ficou em primeiro lugar com luminárias feitas com materiais recicláveis (a). Prêmio Planeta Casa, Categoria Estudante (b), revista Casa Cláudia, São Paulo, SP, 2003. Confeccionada com tubos de papelão. Alunos: Bruno Aburjaile Costa, Fabrício Torres, Luigi Carvalho Comine e Marília Emanuele Bill. 



Figura 35 - Concurso Masisa para Estudantes de Design, Masisa e Centro de Design do Paraná, Curitiba, PR, 2002. Mesa de centro Pettia (a), da aluna Carolina Oliveira Marques. Mesa Piano, da aluna Joceline Gonçalves Fernandes (b). $2^{\circ}$ lugar no concurso e exposta também na Mostra Jovens Designers, no Conjunto Nacional, em São Paulo, SP, .
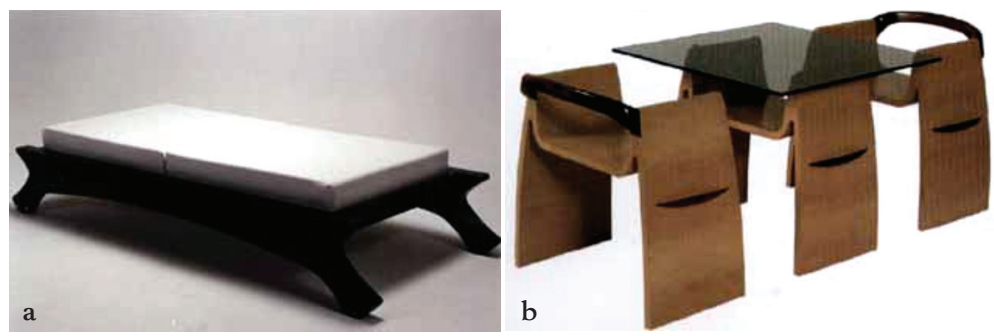

Figura 36 -VIII Edição Salão Design Movelsul, Bento Gonçalves, RS, 2002. Namoradeira Oriental (a), dos alunos Fernando José Soares Silva, Luiz Carlos Bezerra, Lucindo Tomiosso Júnior, Marina Nahoka Wakyama, Ricardo Shikata e Sílvio Tadeu Nascimento França. Cadeira M(b), dos alunos Eduardo Yuji Sato, Márcio Akutsu Takada e Rodrigo César Ramos.
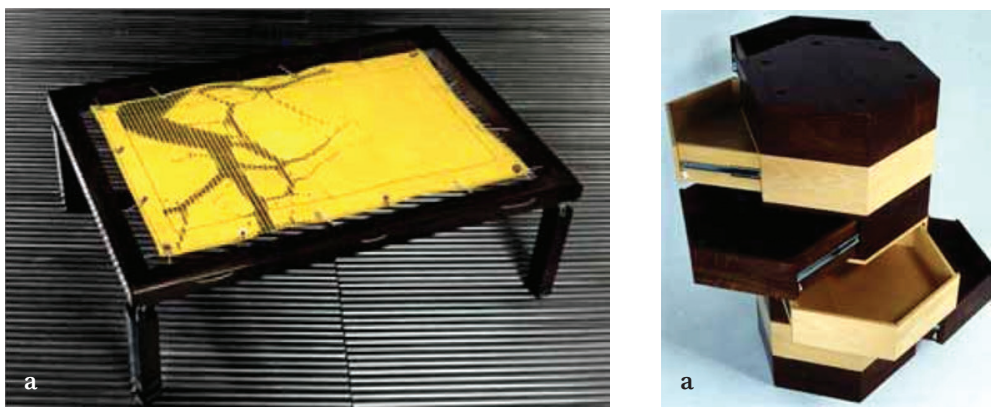

Figura 37 - Mesa Flex (a), $4^{\circ}$ Prêmio Liceu de Design, Liceu de Artes e Ofícios da Bahia, Salvador, BA, 2002. Aluno: Márcio Akutsu Takada. Gaveteiro $360^{\circ}$ (b), VII Edição do Salão Design Movelsul, Bento Gonçalves, RS 2.000. Alunos: Álvaro Ribeiro Lacerda, Fernando José Soares Silva, Lucindo Tomiosso Júnior e Robson Avelino Santos. 
Pretende-se com isso, de acordo com Moraes (idem) que o aluno habitue-se a encontrar por si mesmo, por meio de suas análises e reflexões, novas e diversificadas propostas projetuais, incentivando infinitas possibilidades de solução. Em contrapartida, a expectativa do docente junto a esse modelo projetual é que os resultados alcançados permitam ao aluno desenvolver o lado reflexivo durante as fases de projetação, ou seja, dedicar mais tempo aos aspectos críticos, analíticos, comportamentais, culturais, teóricos e subjetivos a serem aplicados nos projetos de produtos. A mera aplicação dos aspectos objetivos não deve ser mais a forma determinante de método e modelo projetual. E ainda, é importante habituar-se aos temas diversos e genéricos como forma de se preparar para o mercado de trabalho encontrado nas diferentes realidades dos países em via de desenvolvimento, e junto à realidade que se afirma dentro da chamada Era Pós-Industrial.

Portanto, torna-se cada vez mais difícil descrever um caminho exato e preciso para a formação de designers, se é que existe uma rota precisa. Nas palavras de Moraes (idem):

E ainda, qual plano de ensino seria o mais adequado junto às escolas que ensinam hoje esse ofício, sabendo-se que tal atividade vem recebendo influências das constantes mutações comportamentais, tecnológicas e culturais da nossa sociedade. Podemos considerar cada projeto a ser desenvolvido uma nova lição, na qual parte dos problemas a serem resolvidos não foi sequer mencionada durante os anos de formação escolar. Seria, desta forma, a escola limitada a um posto de informação teórica e cultural do design, uma vez que a verdadeira integração escola-indústria não passa de um eterno projeto? Haveria uma escola atuando como modelo? Ou um país de referência em ensino, com um caminho já percorrido com sucesso?

As atividades de ensino superior em design não fazem parte de política pública de design específica, embora a parceria entre as diversas organizações, governamentais ou não, as empresas e as instituições de ensino seja estimulada em diversas metodologias. 
Existem hoje 331 cursos de graduação em design, noventa cursos de pós-graduação latu sensu, seis mestrados e um doutorado. ${ }^{2}$

No cenário acadêmico, alguns eventos merecem destaque: o Ciped - Congresso Internacional de Pesquisa em Design, evento bienal, com sua $5^{\text {a }}$ edição em 2009; o P\&D - Congresso Brasileiro de Design, realizado a cada dois anos desde 1994; o Ergodesign Congresso Nacional de Ergonomia e Usabilidade de Interfaces Humano Tecnologia; o Usihc - Usabilidade de Interfaces Humano-Computador, realizado concomitantemente ao Ergodesign; e o Ndesign - Encontro Nacional de Estudantes de Design, realizado anualmente desde 1991 e organizado pelos próprios estudantes. Considere-se ainda a atuação das diversas associações profissionais em âmbito nacional.

O Brasil tem hoje mais de sessenta faculdades de design, que, estima-se, já concederam diplomas a mais de trinta mil designers.

A esse gigantesco contingente somam-se outros milhares de profissionais de Arquitetura, Decoração e Engenharia que, por causa da retração do mercado de trabalho, avançam em direção às áreas mais próximas e mais frágeis do ponto de vista de sua organização profissional.

Com o desenvolvimento da computação gráfica, ampliou-se também, de modo exponencial, a legião de amadores autodidatas, que atuam sobretudo no atendimento às pequenas demandas por design gráfico. Portanto, devemos contabilizar, no Brasil de hoje, mais de cinquenta mil pessoas que se julgam preparadas ou habilitadas para exercer a atividade de designer.

Essa oferta de design é imensamente maior que sua necessidade efetiva. Estimativas situam o percentual de profissionais atuando na área, empregados ou autônomos, entre 10\% e 20\% dos graduados. Embora essas sejam projeções empíricas feitas a partir da observação do aproveitamento no mercado de trabalho dos alunos recentemente graduados, pode-se tê-las como aproximação bastante confiável.

2 Disponível em: <http://www.designbrasil.org.br/portal/estudantes/index. jhtml>. Acesso em: out. 2008. 
Se a oferta de design está superdimensionada em relação à demanda, isso se deve a uma série de fatores estruturais, entre eles a pressão exercida pela sociedade para a abertura de novos cursos superiores no país, sem que exista uma correspondente possibilidade de absorção desses profissionais pelo mercado de trabalho. As universidades, de modo geral, confundem demanda da sociedade com demanda de mercado.

O agravante nessa superpopulação acadêmica é o baixo nível de ensino do design, que contribui para dificultar a abertura de novas oportunidades de trabalho. A maioria dos professores dos cursos de design é de profissionais com pouca ou nenhuma experiência real e que após algumas tentativas frustradas de ganhar a vida desenvolvendo projetos, descobrem na atividade docente talvez sua única possibilidade de atuação no setor. Saem da universidade por uma porta, na qualidade de alunos recém-diplomados, e entram por outra, como professores concursados.

Com esse sistema, perpetua-se o distanciamento entre a universidade e a realidade das empresas. Pretendem, com essa docência ingênua, ensinar design para um mundo fictício, no qual o mercado é constituído majoritariamente de grandes e modernas empresas, que estão sempre na expectativa de que surjam novos talentos para contratá-los para seus departamentos de design. Porém a realidade é bem diferente, e os prováveis clientes são pequenos ou microempresários, descapitalizados e no desespero da sobrevivência. Somente agora, transcorridos mais de quarenta anos da criação do primeiro curso de design no Brasil, as indústrias estão começando a sentir a necessidade de investir nessa área. Antes considerado gasto supérfluo ou apenas tática mercadológica de agregação de valor a produtos, o design é visto hoje como investimento estratégico no esforço de sobrevivência das empresas.

Em um país cuja política industrial sempre teve forte conteúdo protecionista, era praticamente impedido o acesso da população aos principais produtos fabricados no exterior que tivessem similar nacional, como forma de proteger uma indústria ainda incipiente. Tendo à sua disposição consumidores cativos, por absoluta falta de 
opções, a indústria brasileira, quando tinha de criar um produto, preferia utilizar o expediente da cópia ou do licenciamento. Essa opção era, em princípio, mais barata, mais rápida e menos arriscada.

Durante os últimos trinta anos, o mercado para o design poderia ser resumido em dois grandes grupos. De um lado, algo em torno de mil pequenas empresas atuando quase que exclusivamente com desenho gráfico e embalagens, trabalhando para pequenas firmas demandantes concentradas predominantemente no eixo Rio-São Paulo-Belo Horizonte-Curitiba. De outro, cerca de vinte empresas de médio ou grande porte, com seu departamento próprio de design, empregando entre cinco e dez profissionais.

Esse era o mercado de design no Brasil, e as exceções apenas confirmam a regra. Apesar disso, as universidades continuavam e ainda continuam - formando profissionais para serem empregados. Nenhum dos cursos de design espalhados pelo país ensina os futuros designers a serem empresários e a gerenciar sua própria empresa.

A partir de 1990, esse quadro começou a mudar. Surpreendidas pela política governamental de abertura do mercado, as empresas brasileiras optaram, inicialmente, por estratégias defensivas como forma de proteger-se da concorrência externa.

Em muito pouco tempo, as empresas conseguiram efetivamente conhecer, aprender e colocar em prática os mais avançados métodos de gestão da produção e da qualidade. Desse modo, e sem se preocupar muito com o custo social, conseguiram certificar-se pela ISO 9000 mais de 1.500 empresas no curto período de seis anos. Todo esse esforço de otimização da produção, eliminação de perdas e de desperdício, redução de insumos e de matéria-prima e aumento da produtividade não foi, contudo, suficiente para tornar os produtos brasileiros verdadeiramente competitivos no mercado internacional.

Apesar de todo o esforço, o custo final de produção ainda é muito elevado - sobretudo se comparado com o dos países asiáticos por causa da dificuldade de reduzir os custos dos elementos formadores de preço, tais como mão de obra, insumos e matérias-primas, 
energia elétrica, escoamento da produção, tarifas aeroportuárias e, sobretudo, carga tributária. A soma desses fatores (conhecida como "custo Brasil") onera, sobretudo, as pequenas empresas, que não possuem escala de produção capaz de absorver esses encargos.

A única alternativa viável, pois é impossível competir no preço, passa a ser o oferecimento de produtos diferenciados, singulares e com elevado valor agregado. É a partir dessa constatação que as empresas descobrem que a estratégia mais eficaz de sobrevivência não é atuar na defesa, mas no ataque, utilizando práticas mais ofensivas. E o design é a arma indicada nesses casos.

Para manter um nível de eficiência competitiva, as indústrias dos setores mais dinâmicos, principalmente nos países em desenvolvimento, tiveram de se esforçar, sobretudo nos últimos dez anos, para implantar um processo intensivo de reestruturação produtiva e de reconversão industrial. Trata-se de uma nova cultura industrial baseada no trinômio qualidade, tecnologia e informação, a partir da descoberta de que o mais precioso patrimônio das organizações são elementos intangíveis, baseados no compromisso, na inteligência e na inovação. 


\section{7 \\ Discussão}

Uma mudança ocorre quando há uma revolta contra a pressão das coisas com as quais nós nos acostumamos, mas que são anacronismos e autóctones. Um novo estilo de vida pede novas formas e novas coisas.

O design constitui-se em parte da grande transformação social, econômica e cultural. Diferentes pessoas têm mudado de opinião sobre o significado de um novo design. Algumas são quase indiferentes a seus valores e consideram isto de menor importância, se comparado com o desenvolvimento tecnológico, por exemplo. Mas para a maioria das pessoas a sensação de bem-estar apoia-se largamente nos objetos cotidianos que as rodeiam. As coisas ao nosso entorno, nosso cenário externo, é então a expressão de como a geração mais velha viveu e como nós queremos viver hoje.

A atividade altamente diversificada que caracteriza o design finlandês em todas suas formas foi, na realidade, encarada como uma alternativa "democrático-individualista" para as grandes indústrias ou políticas governamentais que forçaram uma produção mais uniforme nas sociedades de massa em alguns outros países.

Os objetos e produtos que um indivíduo, uma família, uma comunidade ou uma sociedade projetam, fabricam, escolhem e aceitam, e o modo como a relação com vários deles evoluem, refletem 
igualmente valores tanto individuais como sociais. Objetos e produtos falam sua própria e explícita linguagem. Os diferentes pesos dados ao lugar, ao tempo, à cultura e à comunicação resultam em diferentes formas de expressão. $\mathrm{O}$ crescimento assustadoramente rápido das formas de comunicação baseado na tecnologia global incrementou a uniformidade. Seria excitante ver como culturas locais conseguem preservar sua própria identidade. Isso é uma questão de política em design e também de política cultural.

A linguagem formal criada pelo homem para os objetos e produtos é a mesma em qualquer lugar do mundo. A forma do objeto e dos produtos pode ser traçada por meio da interação entre lugar (geografia e ecologia), tempo (história), atividade humana (cultura, incluindo tecnologia) e comunicação (informação). O design finlandês segue o mesmo princípio básico como design e cultura material, mas a ecologia, a história e a cultura finlandesas não seguem o padrão usual de outros países industrializados, o que torna o design finlandês interessante.

Assim como as leis naturais são globalmente válidas, é natural que a tecnologia baseada nessas leis produza técnicas construtivas, máquinas e instrumentos similares, sem levar em consideração o país ou a região onde estão sendo produzidos. É por isso que aviões, carros, televisores, instrumentos médicos, entre outros, parecem os mesmos em todo o mundo. A produção industrial em massa atravessa as fronteiras nacionais, e os mesmos produtos podem ser comprados em diferentes partes do mundo.

Ao contrário, identidade nacional e originalidade podem ser encontradas principalmente no artesanato e na arte industrial enfatizando os aspectos estéticos, mas também na qualidade e no know-how do design. O design nacional finlandês tem conservado alguns dos antigos arquétipos da humanidade, como a relação com a natureza, as necessidades básicas da vida e as ferramentas para satisfazê-las.

A natureza é uma fonte inesgotável de inspiração em várias culturas. O longo, gráfico, preto e branco inverno finlandês tem sido tema e forma para vários produtos de artesanato e design, mas tam- 
bém tem forçado o desenvolvimento de várias ferramentas para sobreviver a ele. Hoje em dia, todas as circunstâncias climáticas que os finlandeses enfrentam são contornadas com a ajuda da tecnologia, permitindo que todas as funções da sociedade continuem com segurança e sem interrupção, independentemente do frio e da neve. Mas dos velhos tempos sobrevive a habilidade em encontrar formas inatas e apreciar a estética e a primitiva beleza da solução formal simplificada.

Os fazendeiros e suas famílias construíam seus próprios objetos e ferramentas, assim como as construções. Por meio da tentativa e erro, a funcionalidade e a forma dos objetos e ferramentas foram gradualmente tornando-se mais práticas e bonitas. Como é fácil de ser trabalhada, a madeira era o material principal. Em função do rigoroso inverno, a terra era pobre, e o padrão de vida, baixo. Por sua vez, os objetos e ferramentas tinham de ser econômicos e frugais. Influências estilísticas que se infiltraram na Finlândia foram adaptadas ao modo simples de vida. Algumas das mais básicas e antigas atitudes e maneiras conhecidas têm sobrevivido na Finlândia como uma tradição viva, defendida pela geografia e pelo idioma não usual.

Os princípios do Funcionalismo - sua ênfase na praticidade, utilidade e simplicidade - estavam em harmonia com a cultura finlandesa, e foi dessa união que surgiram as características básicas do design finlandês. Como tais características, além da percepção da natureza e da simplicidade, pode-se citar a necessidade de uso racional dos recursos naturais, a qual ajudou a compreensão dos princípios do ecodesign e das análises ergonômicas, principalmente em design de mobiliário. Por outro lado, em que pese esse despojamento formal, a exuberância da colorida ornamentação convive lado a lado com a simplicidade. $\mathrm{O}$ artesanato oferece exemplos de efetiva decoração, e o design industrial revela a beleza do Funcionalismo.

A decoração genuinamente finlandesa tem claramente origens no épico Karelia e está diretamente relacionada com influências bizantinas e eslavas, preservadas, por exemplo, pela Igreja Ortodoxa, como contrapeso à visão predominantemente verbal e antipictórica da Igreja Luterana. 
As "minorias silenciosas" - crianças, idosos, deficientes - têm a demanda de suas necessidades atendidas, assim como a maioria. Na Finlândia e no restante da Escandinávia, são comuns trabalhos em brinquedos, ajuda a idosos, roupas e outros equipamentos para deficientes, entre outros importantes resultados de alta qualidade, expressando as várias dimensões humanitárias que o design pode assumir.

O design finlandês tem se caracterizado em diversos países como sucesso de público e de crítica há mais de cinquenta anos. Contribuíram para esse quadro uma intensa atividade pós-Segunda Guerra Mundial, a competição internacional, a postura dos finlandeses em relação ao processo de design, que destruiu as barreiras artificiais entre a produção industrial, e a resposta pessoal aos objetos que dão forma a nosso ambiente. A popular retórica modernista de “coisas mais bonitas para o uso diário" relatou ao mundo o design finlandês como uma cultura emblemática de um ideal democrático. O projeto de design escandinavo fazia parte do projeto pós-guerra da Escandinávia para entrar de maneira agressiva no mercado externo, tendo em vista que o ideal pós-guerra de funcionalismo era imperativamente social, mas com design inexpressivo. E a identidade do design finlandês está focada em concepções sobre os objetos, não nas qualidades formais inerentes a esses objetos, crucial na criação de uma cultura nacional de design nos anos 1940 e 1950.

O sucesso do design finlandês dos anos 1950 está diretamente ligado à consolidação da identidade nacional. Da mesma forma que o moderno tem a ver com a independência, o boom do design finlandês pós-guerra e, consequentemente, os golden years nos anos 1960 têm a ver com as negociações que tiveram de ser feitas com a antiga URSS. Muito pouco mobiliário foi importado, e os produtos disponíveis no mercado interno facilitaram a modernização dos lares finlandeses, ajudando a criar uma imagem coerente entre a Arquitetura e outras áreas do design.

O mundo tem mudado muito desde os anos 1950 e 1960, anos de ouro do design finlandês. A arena do design expandiu-se, especialmente no campo do design industrial. O papel social do design tem 
ganhado profundidade e complexidade, mas também tem se tornado motivo para compreensões contraditórias. A produção em massa e o mercado internacional continuam a crescer, mas encontramse frente a uma relação problemática entre estilos internacional e nacional e a relativa importância do público e do privado - em um mundo onde da qualidade ambiental depende nossa sobrevivência.

O programa de política em design Design 2005! Government Decisions in Principle on Finnish Design Policy é provavelmente um dos mais consistentes e consensuais casos de esforço em escala global para se introduzir o design de modo mais eficiente a serviço da indústria, do comércio e da cultura, apesar de uma política nacional em design não ser novidade na Finlândia. Já em 1871, foi criada a Central School of Crafts, atual Universidade de Arte e Design Uiah, a serviço da então nascente indústria.

De várias maneiras a discussão do final do século XIX, centrada no artesanato, está distante do debate atual, mas apesar do panorama histórico ser diferente, ainda são atuais os argumentos sobre interesse nacional, exportações, o papel do capital privado frente ao eterno problema da balança comercial, arte, estética, artesanato e tecnologia no desenvolvimento de produtos. Talvez a principal diferença seja que agora essas questões estejam embebidas nos problemas da globalização. Assim, a política industrial tem levado em conta o papel do design como forma de melhorar a competitividade das exportações da indústria em um mercado incrivelmente global e saturado. Paralelamente, não se pode esquecer que isso é fato não apenas na Finlândia, mas em vários países, onde também se observam agendas semelhantes de incremento ao design, como no Brasil. ${ }^{1} \mathrm{E}$ todas elas refletem o passado histórico local do contexto de design e sociedade. A História pode ser lida retrospectivamente a partir desses documentos como forma de traçar as similaridades e diferenças entre o presente e o passado. De fato, se adequadamente interpretada, o entendimento da história pode futuramente ter par-

1 Disponível em: <http://www.designbrasil.org.br/portal/acoes/pbd.jhtml>. Acesso em: out. 2008. 
te significativa no entendimento de como essas políticas serão e/ou foram implementadas.

O contexto econômico finlandês mudou rapidamente no começo dos anos 1990, levando o país à sua pior crise enquanto nação independente, e os piores anos da recessão, entre 1992 e 1994, mostraram a fragilidade da infraestrutura da indústria nacional. Era consenso nacional a importância de se redirecionar a indústria para áreas maciçamente tecnológicas, assim como de informação tecnológica. Por outro lado, também era clara a necessidade de investimentos significativos para melhorar o patamar de desenvolvimento tecnológico. Isto equivalia a um significativo aumento no orçamento da Agência Nacional de Tecnologia, que, juntamente com o setor universitário da área tecnológica, eram responsáveis pela $\mathrm{R} \& \mathrm{D}^{2}$ na indústria. Gradualmente, o conceito de um sistema nacional de inovação tornou-se o termo guarda-chuva que abrigava toda e qualquer ação que ajudasse a escapar do limbo econômico e da erosão no sistema social causada pelo fim do estado de bem-estar que tinha se desenvolvido nas décadas depois da Segunda Guerra Mundial.

Apesar de essa discussão estar focada no design, a agenda nacional no caso finlandês não pode ser entendida sem o reconhecimento das mudanças drásticas na indústria, na política tecnológica e nos investimentos em pesquisa e desenvolvimento, cujo exemplo mais conhecido ainda é o caso da Corporação Nokia. Várias das companhias high-tech em meados da década de 1990 exploravam o potencial do design de produtos no desenvolvimento mais intenso e mais estratégico do que já tinha sido usado até então. É evidente que nesse caso o design serviu como vantagem em retorno financeiro, o que nos leva a pensar sobre o novo papel que o design deve ter nas políticas para renovação do perfil dos produtos, não importando de qual país seja.

Em 2000, quando foi lançado o programa, concluiu-se que existia sim a necessidade de uma ampla visão do estado atual e dos futuros desafios do design finlandês. $\mathrm{O}$ meio industrial e os po-

2 Research $\mathcal{E}$ Design. Pesquisa \& Design, em uma tradução livre. 
líticos eram favoráveis a essa visão. A comunidade de design, em somatória, deu atenção a vários tópicos que ainda estavam em discussão, apesar de não no contexto geral de toda a análise. Quando pronto, o documento abrangia basicamente três áreas principais sobre os aspectos do acordo com design em relação à competitividade nacional. Trata-se de uma melhora geral no padrão do design e de desenvolvimento de um profissional em design, mas com um conhecimento sólido na estrutura comercial, a recomendação de colaboração entre os setores público e privado. O Estado seria responsável por áreas tais como educação, promoção cultural e gerenciamento de patrimônio, mas o design só pode florescer e existir em colaboração com a indústria e por meio de consultorias em design capazes de gerenciar seus serviços e negócios em um mercado aberto e competitivo. E no final de 2000, a discussão pública sobre design atingiu, inclusive, setores da mídia que antes eram reservados para notícias sobre economia. Aparentemente, o único obstáculo encontrado era a comunicação entre designers, engenheiros de profissionais de marketing. A solução encontrada foi o desenvolvimento de um programa IDBM $^{3}$ conjunto entre o curso de mestrado da Uiah, a Universidade de Tecnologia ${ }^{4}$ e a Escola de Economia e Administração de Negócios, ${ }^{5}$ o qual recebeu um orçamento especial do Ministério da Educação.

A organização desenvolvida pela Uiah desde o final dos anos 1980 ilustra a política tanto educacional como de natureza estratégica de que a universidade é capaz, não apenas respondendo aos desafios de redefinir o cenário do design, mas também de, atualmente, formular várias das principais questões. Isto tem se concretizado por meio de uma plataforma internacional para discussão em educação e pesquisa em design, operacionalizada com uma série de conferências internacionais iniciadas em 1987, em colaboração com líderes internacionais do cenário em design. O resultado des-

3 International Design Business Management.

4 Helsinki University of Technology.

5 School of Economics and Business Administration. 
sas conferências tem sido publicado desde o final dos anos 1980, tornando-as o principal editor de livros, dissertações e periódicos em design.

Outro elemento é a mobilidade dos estudantes, tanto de estrangeiros para a Finlândia como vice-versa. Dessa forma, é sublinhado o papel da pesquisa em produzir e expandir conhecimento em design em qualquer esfera. Paralelamente, a pesquisa em design tem surgido nas universidades de tecnologia e economia, com potencial para abordagens multidisciplinares. Em sintonia com a preocupação de transferir inovação de natureza tecnológica dos projetos desenvolvidos na universidade para possíveis aplicações industriais, foi criado um centro para design como parte da política, Designium. ${ }^{6}$

Esse centro de inovação em design é constituído em estreita colaboração entre a Universidade de Arte e Design de Helsinque, a Universidade da Lapônia, a Universidade de Tecnologia de Helsinque (HUT) e a Escola de Economia de Helsinque (HSE). ${ }^{7}$ A cooperação também inclui outras universidades, empresas e organizações públicas. Sua missão é promover o desenvolvimento da política nacional em design e a internacionalização do design finlandês. $\mathrm{O}$ objetivo é colocar o design como o fator principal de competitividade na indústria finlandesa. Seus colaboradores pretendem torná-lo

6 Designium irá fomentar novos campos em design, assim como aqueles já consagrados no mercado, através de pesquisas multidisciplinares, visando à exploração comercial de resultados. A pesquisa deverá ser apoiada pelo desenvolvimento de novas formas de cooperação em matéria de inovação, de forma a responder às necessidades do sector empresarial. O objetivo será promover o uso da experiência do design em inovação e desenvolver atividades na área comercial, gerando, a partir daí, outras inovações. Isso será feito em cooperação com os todos os departamentos e unidades da Universidade de Arte e Design Helsinque, responsáveis pela pesquisa e ensino, cuja experiência em design também constitui a base para P\&D no Designium, produzindo conhecimento sobre a situação atual e as tendências internacionais em design, implementando programas que promovam o desenvolvimento do design e crie novos contatos internacionais. Disponível em: <https://www.taik.fi/designium/ english/>. Acesso em: 13 set. 2006.

7 A fusão dessas instituições já foi aprovada pelo Parlamento e está em processo de implantação, devendo ser concluído em 2009. 
um grande centro de competência em design, tanto nacional como internacionalmente, promovendo a internacionalização do design, com impacto positivo considerável na economia nacional.

Entre 2004 e 2007, esse centro promoveu a transferência dos novos conhecimentos e aptidões em design para o setor empresarial, e também a utilização do modelo em design pela economia, visando alcançar um crescimento significativo da competitividade internacional finlandesa e a consequente melhoria do emprego na Finlândia.

Desta forma, de acordo com as recomendações da política em design, uma espécie de mesa-redonda de design tem sido estabelecida com representantes da indústria, da educação, dos designers e do setor público, de maneira a gerar iniciativas para as instituições decisórias, tanto públicas como privadas. A Uiah tem se mostrado em conexão com várias das ações e iniciativas relatadas. Isto é consequência do papel que a universidade ocupa no campo do design finlandês, não apenas na educação e pesquisa, mas também em política em design. As operações da universidade são um bom exemplo de colaboração frutífera entre a educação superior e outras instituições públicas e privadas.

No Brasil, esse processo desenrolou-se de forma diversa ao acontecido na Europa, o que gerou, em seu decorrer, a hibridização de uma sociedade "pré-industrial" existente e uma outra "industrial em formação", em que o tradicional e o moderno articularam-se desigual e combinadamente para formar uma outra, nem totalmente tradicional, nem totalmente moderna, mas múltipla e sobreposta.

A modernidade brasileira foi um conjunto de valores elaborados em pátrias distantes, pátrias estas que são tomadas como referência. A apropriação da modernidade pela sociedade, na maioria dos casos, ocorre por meio dos "modelos", ou seja, não porque se tenha uma compreensão, mas porque é o repertório formal das elites, a qual, por sua vez, "consome" o moderno, igualmente não porque o entenda, mas porque em um determinado momento foi repertório formal vanguardista, que o distanciou da massa, em uma relação que se retroalimenta. 
A instituição do design no Brasil ocorre de modo forçado. É a história de uma cultura importada, assim como o modelo de industrialização pode ser entendido como sendo o de uma industrialização forçada, não espontânea, que nem sempre se apresentava de acordo com a razão do design local, na qual se foi inserindo ao longo dos anos sua cultura autóctone. Trata-se de um percurso muito complexo, um grande esforço, sobretudo por parte da presença europeia, para fazer crescer em um país que não tinha nem vocação, nem tradição, nem ocasião, a cultura do projeto moderno aplicado aos objetos de produção em série.

O próprio modelo de design que as minorias europeias procuraram introduzir no Brasil baseava-se em pesquisa de produtos definitivos, projetados racionalmente para uma sociedade ordenada e monológica. Com o passar dos tempos, o mercado encarregou-se de demonstrar não somente a impossibilidade desse teorema, mas também sua periculosidade como portador de uma rigidez produtiva, em um contexto mundial, que hoje, ao contrário, pede contínuas inovações.

Diante disso, o ensino apresentava-se aos designers brasileiros como a melhor alternativa para colocar em prática suas próprias percepções e conceitos experimentais da atividade de design. É curioso notar que as melhores soluções projetuais surgidas no país no âmbito escolar não foram colocadas em prática nas indústrias locais. Permaneceram como propostas e protótipos no âmbito acadêmico, como nos confirmam os inúmeros prêmios e concursos de design promovidos no país, longe, portanto da produção e dos reais vínculos industriais que os legitimassem.

No Brasil, segundo Vasconcelos \& Ferreira (2000), a inovação tecnológica tem sido tema de diversas publicações, e o relato de experiências de sucesso aponta para a necessidade do fortalecimento da interação entre governo, universidades e empresas.

O processo de inovação é um processo interativo realizado com a contribuição de vários agentes econômicos e sociais, que possuem diferentes tipos de informação e conhecimento, e dentro desse contexto, é necessário que se desenvolvam políticas industriais, tecnoló- 
gicas e de inovação que sejam capazes de lidar com a realidade socioeconômica, tornando-se urgente o incentivo do governo à criação de redes, nas quais os recursos, o conhecimento e a informação circulem rapidamente e a baixos custos e as quais são extremamente importantes para orientar e adaptar os sistemas produtivos e de inovação, que devem envolver o setor industrial, o setor de ensino e de pesquisa e o governo, que, em articulação com outros agentes, podem contribuir para a aprendizagem das empresas, o fortalecimento de sua capacitação tecnológica e o consequente aumento de sua competitividade.

Especificamente no caso da inovação em design, em que pese que a empresa venha a ser o lócus do processo de inovação, esta não está sozinha nesse processo, pois necessita de articulação com os demais agentes. O processo de inovação é, portanto, um processo interativo, realizado com a contribuição de vários agentes que possuem diferentes tipos de informação e conhecimento, e essa interação se dá entre diversos departamentos da mesma empresa, entre empresas diferentes ou entre distintas organizações, como centros de pesquisa e universidades.

Ressalta-se o papel das instituições de pesquisa e das universidades, que fornecem a base do desenvolvimento científico e tecnológico para a geração de conhecimentos e capacitação de pessoas. Uma vez que a competitividade das empresas no mundo globalizado depende da inovação de produtos e processos e do esforço de $\mathrm{P} \& \mathrm{D}$, seus dirigentes deparam-se com um grande desafio. Nos países desenvolvidos - como foi o caso da experiência observada na Finlândia -, a interação entre o setor de pesquisa e o setor empresarial faz parte da estratégia das empresas na gestão de seu conhecimento tecnológico.

No Brasil, o afastamento do setor privado das atividades de $\mathrm{P} \& \mathrm{D}$ contrasta com esse comportamento dos países desenvolvidos. Como consequência, a indústria brasileira perde a oportunidade de investir no desenvolvimento de capacidade inovativa e em processos criativos de aprendizado conjunto.

Para se gerenciar de forma efetiva as cooperações entre universidades, centros de pesquisa e indústrias, vários pontos precisam ser 
esclarecidos e analisados, pontos estes que vão desde a definição do que seja uma cooperação de sucesso, dos critérios que possam ser usados para avaliar a eficiência de uma pesquisa em cooperação, até as causas mais comuns dos fracassos e frustrações, incluindo, principalmente, como se dá o processo de aprendizagem nas empresas. De acordo com Vasconcelos \& Ferreira (idem):

- o projeto deve ser igual mente importante para ambos os parceiros, levando-se em consideração que as motivações raramente coincidem;

- cada parceiro (universidade, indústria) deveter sua identida de e seus objetivos próprios respeitados. Por exemplo, encontrar compromissos entre as diferentes temporalidades;

- a comunicação - essencial - não deve se referir apenas aos resultados alcançados, mas também ao processo de trabalho. A probabilidade de sucesso aumenta com a frequência e o caráter personalizado dessa comunicação;

- a capacidade de motivação das equipes por seus líderes deve ser apoiada pela construção de redes de interação estáveis entre equipes industriais e universitárias;

- e, final mente, énecessário levar em consideração as diferenças entre as representações de acadêmicos e industriais no que diz respeito à aprendizagem (passagem de um enfoque conceitual a outro, procedimental), ao valor (valor de estima versus valor de troca) e às emoções (ruptura da relação entre o criador e a criatura, representação de seu universo mental, em oposição ao prazer do risco e da vitória no mercado). Investir no desenvolvimento de representações comuns do sucesso da interação é importante para seu bom andamento.

Neste artigo que relata a experiência do Projeto Minas Ambiente, Vasconcelos \& Ferreira (idem) apontam algumas ações necessárias para o sucesso nesse tipo de parceria:

- formação de recursos humanos, em nível de pós-graduação, sensíveis às necessidades da indústria; 
- solução de problemas tecnológicos da indústria por meio do desenvolvimento de projetos de doutorado e mestrado;

- indução do processo de participação da indústria e do setor privado em geral no financiamento da pesquisa e da pós-graduação;

- formação de interlocutores e negociadores da cooperação entre universidades, indústrias e centros de pesquisas;

- conscientização dos pesquisadores quanto à importância das patentes e consequente aumento no número de pedidos;

- maior participação do setor privado na definição das políticas públicas de pós-graduação;

- desenvolvimento de ferramentas catal isadoras da transferência de conhecimentos entre o setor de pesquisa e a indústria;

- formação de mestres e doutores mais val orizados pela indústria e fortalecimento da integração universidade, indústria, centros de pesquisa.

Atransiçãodasdécadasde1980e1990foimarcadapeloPlanoCollor e pela entrada do Brasil no mercado globalizado. A indústria nacional precisou enfrentar a competição internacional e, consequentemente, foi necessário buscar um diferencial competitivo para os produtos. O design tornou-se uma importante ferramenta para os negócios.

O primeiro programa de âmbito nacional em design no Brasil só surgiu em 1995, enquanto medida de suporte para auxiliar as empresas frente ao contexto de crise econômica dos anos 1980 e de orientação neoliberal dos anos 1990. Foi em 1995 que o Ministério do Desenvolvimento, Indústria e Comércio Exterior MDIC lançou o Programa Brasileiro do Design - PBD (Decreto de 9.11.1995), uma iniciativa voltada para a inserção e o incremento da gestão do design nos setores produtivos brasileiros. ${ }^{8}$ Esse programa reuniu instituições tais como a Confederação Nacional da Indústria (CNI), a Financiadora de Estudos e Projetos (Finep), o Serviço Nacional de Aprendizagem Industrial (Senai), a Federação das

8 Disponível em: <http://www.designbrasil.org.br>. Acesso em: set. 2008. 
Indústrias do Estado de São Paulo (Fiesp), o Ministério de Ciência e Tecnologia (MCT), o Ministério do Desenvolvimento, Indústria e Comércio (MDIC), o Conselho Nacional de Desenvolvimento Científico e Tecnológico (CNPq) e outros.

A definição dos projetos e ações a serem desenvolvidos pelo PBD foi, até 1999, estabelecida anualmente pelo Comitê Executivo, a partir das propostas dos representantes dos subprogramas gerais e dos programas setoriais. Entretanto, "com a institucionalização dos Fóruns de Competitividade das cadeias produtivas pelo Ministério do Desenvolvimento, Indústria e Comércio Exterior MDIC, o PBD passou a desenvolver projetos e ações em consonância com esses Fóruns".

O PBD também incentivou o desenvolvimento de programas estaduais de design que, a partir criação do Via Design, passaram a ser incorporados pelos núcleos e centros regionais.

As bases das diretrizes estratégicas atuais para o design foram elaboradas com fundamentação em uma discussão ampla promovida pelo PBD em outubro de 2002, com a participação de 37 instituições representantes da comunidade do design brasileiro, que deu origem ao documento "Caminhos do Design". Por meio de uma análise das forças e fraquezas, ameaças e oportunidades para o design, foram definidos a missão, os princípios e valores, as diretrizes estratégicas, as linhas de ação e os programas e projetos.

As iniciativas de promoção do design nesse período incluem: o projeto Design Excelence Brasil, lançado em junho de 2003, que busca o reconhecimento internacional do design brasileiro; o fortalecimento da Marca Brasil e da imagem do design do país por meio do apoio à participação de produtos brasileiros em premiações internacionais de design ${ }^{9}$ a criação do Portal Design Brasil, lançado em 2004 para divulgação de informações e trabalhos acadêmicos; o lançamento da Marca Brasil, selo que identifica os produtos, serviços e destinos turísticos brasileiros no exterior.

9 Disponível em: <http://www.designbrasil.org.br/debrazil >. Acesso em: set. 2008. 
Na modalidade de promoção estão, ainda, as mostras e concursos, tanto de caráter nacional como regional, para designers e empresas. Editoras, revistas, revistas especializadas, revistas acadêmicas e jornais, bem como revistas eletrônicas, completam o quadro de promoção, contribuindo para a divulgação e transmitindo informações de design.

Do ponto de vista das atividades de suporte, existem programas dentro das três modalidades previstas: programas de curta duração, de assessoria contínua e de treinamento em geral, implementados por meio de ações do Sebrae e do Senai, com destaque para o programa Via Design do Sebrae e o programa Senai de Gestão do Design, que estão integrados às políticas de desenvolvimento regional.

Enquanto parte do processo de busca de aperfeiçoamento, as políticas de design têm passado também por avaliações e controle de impactos. Em outubro de 2006, uma nova reunião de avaliação estratégica do PBD reorganizou suas diretrizes de acordo com as indicações levantadas em estudos sobre o panorama do design em nível internacional e nacional (Miasaki et al., 2006), dando início a uma nova etapa, o PBD 2007-12. Algumas preocupações foram então enfatizadas, entre as quais se destacam a necessidade de maior apoio à educação, a inserção em Arranjos Produtivos Locais $\mathrm{APL}^{10}$-, a ênfase nos projetos voltados para a sustentabilidade econômica, ambiental e social e a importância de uma maior coordenação entre as diversas ações e projetos (Brasil, 2003).

Esses pontos fracos revelaram a falta de uma ênfase maior na dimensão antropológica na aplicação dos programas e ações, extremamente centrados na questão do suporte e promoção do design, o que pode parecer coerente, embora não suficiente, do ponto de vista de criação do valor simbólico do design. A promoção do design suscita não somente questionamentos quanto ao seu peso relativo no conjunto de ações, mas quanto a sua própria natureza, pelo fato

10 Arranjos Produtivos Locais são aglomerações territoriais de agentes econômicos, políticos e sociais - com foco em um conjunto específico de atividades econômicas - que apresentam vínculos, mesmo que incipientes. 
de não se apoiar sempre em valores concretos ou em um sistema bem estruturado. Corre-se, então, o risco de desgaste do termo e da imagem do design no Brasil.

Assim, a promoção deve corresponder ao estágio efetivo de desenvolvimento. É necessário que haja uma base de conhecimento para interpretar e selecionar as informações que chegam, transformá-las e traduzi-las em design. Exemplo marcante de uma tentativa de promoção mal direcionada é o caso da exibição em Hanover de produtos que ganharam "prêmios" enquanto plágios: segundo Bornancini \& Petzold (2002, p.136), "pelo menos em duas vezes produtos brasileiros foram contemplados com o troféu 'Plagiários' 'prêmio' distribuído na feira de Hanover à cópia mais descarada de produtos alemães".

Outro exemplo é o desgaste interno do termo design, quando as metodologias de sua implantação não são bem-sucedidas e levam as empresas a não mais acreditar em suas vantagens - o que ocorre com frequência no nível de aplicação de metodologias de APL em regiões menos desenvolvidas.

De um ponto de vista mais abrangente, as políticas de design não lidam com determinados componentes importantes, os quais hoje fazem parte do escopo de ação do design no panorama internacional e que dizem respeito à reorientação ética do consumo. Estando historicamente atreladas à questão da industrialização, essas políticas surgiram no Brasil a partir de iniciativas ${ }^{11}$ de uma liderança exercida por empresários e administradores esclarecidos desde a década de 1970, com foco no desenvolvimento microeconômico, o que é bastante revelador, pois se restringem à visão que coloca o desenvolvimento como consequência do crescimento econômico e não se integram necessariamente aos requisitos da

11 Tais como criação do setor de Desenho Industrial do Centro Tecnológico de Minas Gerais - Cetec (Moraes, 2006), a criação do Laboratório de Desenho Industrial no Instituto Nacional de Tecnologia , no Rio de Janeiro, a criação de um núcleo de design industrial, por meio da ação do governo do estado de São Paulo e da Federação das Indústrias em 1979 (Miassaki et. al., 2006; Loschiavo dos Santos, 1995). 
sustentabilidade. Sua abrangência está subordinada aos objetivos das políticas para as quais atuam como acessórias - melhorias da competitividade das empresas, crescimento econômico do país ou, eventualmente, sustentabilidade-, dependendo do direcionamento dos programas aos quais elas estão atreladas, podendo, assim, servir a propósitos diversos, mesmo opostos à sustentabilidade.

Políticas que beneficiassem mais diretamente causas sociais ou que se preocupassem mais com as questões ambientais teriam uma ação mais transversal e estariam provavelmente mais bem articuladas com as atuais políticas de desenvolvimento.

Para que possa ter uma base mais sólida, o design deve ser inserido enquanto preocupação cultural em um sentido mais amplo. Entendido dessa maneira, o design enquanto cultura entrelaçaria-se com outras políticas, redefinindo as premissas do desenvolvimento social, considerado em posturas tradicionais e conservadoras como decorrente apenas da prosperidade econômica.

Dentro do quadro da aplicação das políticas de design não parece haver uma articulação efetiva com políticas capazes de construir estruturas sociais e econômicas mais adequadas. Por outro lado, a orquestração das atividades conduz muitas vezes a direções divergentes, diluindo o impacto local das ações, uma vez que as diversas instituições não atuam de forma sistêmica e as diferentes instâncias de poder - federal, estadual e municipal - adotam estratégias com frequência conflitantes.

No que diz respeito às políticas culturais brasileiras, que se ocupam diretamente da dimensão sociológica da cultura, elas não contemplam questões que possam beneficiar em maior grau o design, estando restritas aos limites de seu principal instrumento, as leis de incentivo à cultura. Desta forma, as políticas públicas que têm maior potencial para suprir os aspectos deficientes nas políticas específicas de design são efetivamente as políticas de desenvolvimento.

A capacidade de planejamento no Brasil parece ter sido desestruturada durante a crise dos anos 1980 e o neoliberalismo dos anos 1990, o que explicaria a desarticulação entre as diversas políticas públicas e a falta de visão sistêmica do detalhamento das ações es- 
tratégicas e diretrizes. As próprias políticas de uma mesma área são desarticuladas entre si, apesar dos esforços de planejamento que já começaram a ser esboçados a partir de meados da década de 1990.

Assim, o PPA 1996-1999 - Plano Pluri-anual de Ações do Governo Federal "Brasil em Ação" propôs um planejamento efetivo para a economia e uma de suas metas foi o setor de Ciência e Tecnologia, visando, porém, a produção de alta tecnologia.

O design acabou por ser contemplado de forma mais generalizada dentro do projeto de desenvolvimento social, que previa o apoio a pequenas e microempresas, cooperativas e associações, não tendo, no entanto, atingido os objetivos propostos. Destaca-se nessa época a criação dos Núcleos de Apoio ao Design do Serviço Nacional da Indústria - NAD/Senai (1998), que, organizados em rede, passaram a auxiliar as indústrias na inclusão de uma gestão do design em suas estratégias. Entretanto, ainda é necessário que o governo faça "um esforço no sentido de reconstruir a sua capacitação em planejamento e na definição de prioridades", uma vez que "o que se tem visto é uma grande desorganização na execução das ações na área de ciência, tecnologia e inovação". Os recursos financeiros disponíveis, que são insuficientes, são alocados de forma não planejada e pulverizada, incapaz de promover a mudança estrutural necessária.

A falta de coordenação entre as políticas de design e as políticas industriais e de desenvolvimento é um exemplo dessa falta de estruturação. Por exemplo, os problemas enfrentados pelo PBD quando de sua criação com a falta de apoio pelos demais ministérios dentro do próprio governo, bem como a falta de recursos. Essa situação já evoluiu de forma favorável, desde então, na busca de uma maior integração entre as instâncias governamentais, que, entretanto, não é efetiva. Subsistem ainda outros problemas, como a inadequação das políticas a setores de baixa tecnologia, que dizem respeito a pequenas empresas com grande necessidade de apoio. As políticas de inovação privilegiam os produtos e processos de alta tecnologia, ${ }^{12}$

12 Os setores indicados como prioritários são os de alta tecnologia, incluindo semicondutores, software, fármacos e medicamentos e bens de capital. 
ignorando que as dimensões organizacionais e estéticas da inovação poderiam em muito beneficiar os setores tradicionais - tais como o mobiliário, que foi a primeira base de implantação do design no Brasil. Assim, a atual Política Industrial, Tecnológica e de Comércio Exterior - Pitce e a Lei de Inovação visam principalmente o desenvolvimento tecnológico, a inserção externa e a modernização industrial. Os incentivos fiscais atingem principalmente as grandes empresas, adeptas do regime fiscal de lucro real, e as linhas de crédito são de difícil obtenção e difícil operacionalização para as pequenas empresas.

Dentro dos planos estratégicos mais recentes do governo, o incentivo ao design, principalmente nas pequenas e médias empresas, tem se articulado mais de uma forma indireta do que por meio de políticas industriais específicas. A inserção das estratégias regionais dentro de uma estratégia federal passou a ser mais bem estruturada no que diz respeito ao design a partir do PPA 2000-2003, que propôs um planejamento regional e uma nova cultura gerencial. Um dos programas estratégicos foi o desenvolvimento de micro e pequenas empresas - ampliando a atuação de instituições tais como o Sebrae, que em 2002 implantou o programa Via Design, ligado ao PBD.

A principal estratégia do Via Design, uma tentativa de ação conjunta nas 27 unidades federativas do país, é promover a agregação de valor a produtos e a serviços por intermédio de ações de design, com ênfase na melhoria da competitividade global das micro e pequenas empresas. O programa tem duas vertentes, uma estruturante, outra de disseminação do design. Na vertente estruturante, o objetivo é a implantação de uma infraestrutura de prestação de serviços de design para a pequena empresa por meio da criação de centros e núcleos de infraestrutura, que teve um financiamento inicial previsto no edital Via Design 01/2002, posteriormente ampliado por meio do edital Via Design 02/2005.

Assim, os centros de design surgiram, em sua maioria, a partir do Via Design e têm assumido diferentes formas, podendo estar ligados a universidades, a centros de pesquisa ou a entidades de classe (Miasaki et al., 2006). 
A partir de 2004, foi reforçada a ênfase no design em conjugação com o esforço de desenvolvimento de APL no Brasil. O Ministério do Desenvolvimento, Indústria e Comércio Exterior inseriu a política industrial como um dos eixos centrais de estratégia de desenvolvimento em seu PPA para o período 2004-2007. O desenvolvimento de APL foi uma das estratégias adotadas para desenvolver essa política industrial enquanto mecanismo de apoio à base regional de desenvolvimento em conformidade com os valores sócio-regionais.

As concentrações de empresas passaram a ser estruturadas sob a forma de APL, sistemas complexos formados por elementos organizados por meio de relações que buscam superar a individualidade dos negócios para atuar e realizar negócios coletivos. Cada APL tem estruturas que procuram funcionar por meio de lógicas próprias, permeadas pelos interesses dos atores locais. Assim, a atuação do Via Design procura uma ligação com o desenvolvimento regional e setorial, articulando-se com os APL inseridos nas diretrizes estratégicas do Sebrae.

Entretanto, a distância entre o desempenho do design e o da indústria brasileira continua evidente. Apesar da existência de esforços que procuram coordenar ações direcionadas pelas políticas públicas entre as diversas instituições - tais como o Sebrae e o Senai -e ministérios - tais como o MCT e o MDIC -, a coerência sistêmica das iniciativas ainda é discutível, as ações entre os diversos órgãos e programas continuam desconexas e desarticuladas e a metodologia de ação junto a empresas e seu gerenciamento tem sido implementada "com objetivos mal definidos, recursos insuficientes e [...] falta de recursos humanos, além das deficiências no sistema [...]". Por outro lado, vale ressaltar que as metodologias ainda estão em fase de construção e o prazo decorrido ainda não foi suficiente para chegar a resultados efetivos.

A indústria brasileira continua a se desenvolver dentro do ritmo da economia. Segundo Moraes (2006), ela não se destaca hoje por sua competitividade e não criou uma identidade forte. $\mathrm{O}$ design, por sua vez, trilha caminhos autônomos. Assim, existem hoje no 
Brasil duas trajetórias de sucesso a ele ligadas: uma de orientação inovadora, articulada com a cadeia global sem passar necessariamente pela mediação da indústria brasileira; e outra que explora as habilidades e a tradição artesanais.

No primeiro caso, o diálogo é essencialmente global e muitas vezes sequer transita pelo local, não trazendo maiores contribuições para a indústria brasileira, alvo inicial das políticas públicas. $\mathrm{O}$ sucesso do grupo ligado a essa trajetória suscita reflexão e levanta pelo menos duas questões relevantes: a incapacidade das políticas públicas de promover um ambiente interno propício à articulação desse design inovador, e o potencial de desenvolvimento da criatividade e da inovação narrativa dos designers brasileiros quando atuando sob condições favoráveis.

Por sua vez, a evolução da outra vertente do design no Brasil - o design-artesanal, desvinculado da grande indústria -, respondendo a uma tendência social mais ampla, deixa entrever um grande potencial do ponto de vista de estruturação antropológica, a qual privilegia a perenidade e a tradição, bem como o respeito ambiental, articuláveis à produção de pequenas e médias empresas.

Desta forma, mesmo se as políticas públicas brasileiras de design têm evoluído na procura de uma base sustentável, elas devem, dados os limites de sua abrangência, buscar uma reorientação interna e uma melhor articulação com outras políticas. Só a partir do momento em que o design passar a ser compreendido não apenas como "elemento agregador de valor", mas também como elemento estruturante da cultura e da sociedade, é que ele poderá contribuir de maneira efetiva para o desenvolvimento do país.

Basicamente, as estratégias de design são estabelecidas para suprir uma deficiência de mercado - como desenvolver a capacidade de empresas locais - ou cultural - como a reafirmação da identidade local - ou ainda para atender objetivos mais específicos, como o ecodesign.

Devido à dificuldade de medir os resultados de programas de design, a escolha por um ou outro tipo de ação fica sujeita à interpretação da demanda e adequação da estratégia. Nesse sentido, a 
compreensão das necessidades e prioridades locais fica sendo uma atividade crucial para o desenvolvimento da política de design.

Uma forte característica dos programas de design está na diversidade de estruturas e estratégias para solução dos problemas. No entanto, essa diversidade também deve ser interpretada como uma falta de referência, uma ausência de exemplos reconhecidamente bem-sucedidos. Soma-se a isso o fato de que em muitos países as iniciativas de design são estabelecidas bem antes de um plano nacional que as direcione. Ao contrário, a realidade mostra que programas de design são muitas vezes implementados sem estudo do cenário local.

A falta de planejamento nas iniciativas de design é, em grande parte, responsável pelo baixo impacto dos programas de design junto a economias ou sociedades. A falta de uma política geral deixa os programas, e seus resultados, isolados de um plano geral de ação para o desenvolvimento do país.

Considerando as dimensões do Brasil, torna-se necessário destacar a importância da descentralização dos programas de design no país. As estratégias devem ser diferenciadas por regiões e, sempre que possível, por setores industriais, a fim de suprir com eficácia a demanda de cada área. Essas ações necessitam de pesquisas qualitativas, de novas tecnologias adaptadas às suas realidades, de matérias-primas alternativas e de metodologias apropriadas aos processos de produção, que dinamizem as atividades e habilitações locais sem alterá-las em sua essência. Dessa forma, o designer que estiver comprometido com a cultura regional e com esses processos produtivos terá um papel importante em seu desenvolvimento, pois, além da formação acadêmica e do conhecimento técnico, conseguirá fazer com que suas contribuições sejam mais facilmente compreendidas por todos os envolvidos.

Por outro lado, o desenvolvimento pode ser entendido como um processo de potencialização das oportunidades e características existentes em cada território. Frente às diferenças geográficas, econômicas, sociais e culturais existentes, em especial aquelas referentes à atividade do design, percebe-se uma participação considerável 
de profissionais comprometidos com suas regiões, não só contribuindo efetivamente na formulação de políticas que visem destacar e valorizar a produção e os produtos, como também contemplando em seus projetos as influências culturais e as especificidades da região onde estão inseridos.

Motivado pela necessidade de discutir questões relativas ao desenvolvimento descentralizado e a identidade da produção regional, foi criado, em novembro de 1996, o PBD. A iniciativa envolveu alguns conjuntos de autoridades governamentais, empresários, representantes dos segmentos da sociedade civil, instituições acadêmicas, profissionais de design e outras áreas afins e teve como objetivo qualificar a exportação nacional, mais propriamente o produto brasileiro, visando torná-lo mais competitivo. Como consequência, sua criação suscitou o surgimento, em quase todo o país, de programas estaduais de design.

Dentro dessa perspectiva, os programas foram catalisadores de conversas e de ações e promoveram discussões em diversos níveis. Essa atividade, além de ter possibilitado a identificação de um contingente de profissionais disposto a "arregaçar as mangas" de forma até ousada e contundente, sensibilizou as autoridades e a cadeia produtiva brasileira no sentido de perceber a atividade de design como economicamente necessária e estrategicamente indispensável.

Mesmo tendo consciência de que, do ponto de vista dos resultados consolidados pelas entidades envolvidas, as ações empreendidas pelo programa nacional e seus similares estaduais tenham sido modestas, pode-se constatar que desencadearam o início de um movimento descentralizador dos diferentes participantes da cadeia produtiva nacional, cuja essência expressa-se no reforço das características e habilidades específicas e na manifestação da cultura de cada local, contrapondo-se, mesmo que timidamente, ao traço histórico de conservadorismo manifesto na ênfase até então posta somente na ampliação e no fortalecimento dos centros mais desenvolvidos.

Hoje, mesmo com enormes distorções e simplificações, o design é uma atividade reconhecida como fundamental para quem procura 
qualificar seus produtos e torná-los mais competitivos, independente da região onde estejam sendo produzidos. Como exemplos, podemos destacar algumas iniciativas:

- o crescimento, o reforço em qualidade e o investimento em design do polo moveleiro gaúcho, revelados não só em eventos como a Feira Movelsul, mas também no aumento significativo de suas exportações, com resultados expressivos para a economia da região e do país;

- a qual idade e os aspectos nitidamente regionais percebidos na produção moveleira mineira, que propiciou a organização dos profissionais de design daquela região com o objetivo de assessorar e aprimorar o produto local;

- acriativaediversificada produção daindústriaedos designers de mobiliário paulistas, que, em função de seu arrojo e expressão formal, apresentam uma nítida característica urbana e cosmopolita com aceitação internacional;

- as características culturais, os materiais eas habilidades técnicas que impregnam a pequena e crescente produção moveleira pernambucana, que, por sua originalidade e qualidade, sensibilizou os europeus na última Feira de Milão;

- em Pernambuco, na região do agreste, a efetiva participação do design no fortalecimento do setor de confecção, que leva em conta as habilidades e a tradição do segmento, nas cidades de Caruaru, Toritama e Santa Cruz do Capibaribe comprova o citado movimento descentralizador.

Esse movimento em Pernambuco é resultado de um plano de identificação dos arranjos produtivos promovido pelo governo do estado, que visa a implantação de centros tecnológicos. $\mathrm{O}$ projeto, que tem nas habilidades dos municípios e da região em seu entorno a referência básica, baseia-se em três pontos principais: a educação profissional, o estímulo à capacidade empreendedora e a inovação tecnológica, na qual se insere claramente o design.

Existem, ainda, outras ações nas quais as questões relativas à regionalidade estão presentes. Vale destacar a importância do envol- 
vimento de instituições, como a Confederação Nacional da Indústria - CNI, preocupada com a identificação da demanda de design em todo o país; o Sebrae, que vem discutindo nossas características mais identificadoras e "exportáveis" no Projeto Cara Brasileira, além de incluir do design na assessoria a micro e pequenas empresas; e, mais recentemente, as redes estaduais de design, instaladas em vários estados do país, com seus centros e núcleos voltados para o apoio dos arranjos produtivos de cada uma das regiões.

O importante nessa abordagem sobre a "regionalidade" é compreender que vivenciamos um inevitável movimento descentralizador, em que múltiplos e pulverizados centros menores nos apresentam suas criações, com características e habilidades específicas, desenvolvidas com o apoio dos designers locais, e que essas contribuições não são melhores nem piores do que aquelas de regiões mais desenvolvidas. São apenas diferentes. Não é possível deixar de perceber a existência de uma efervescente, importante, criativa e inovadora prática em desenvolvimento nas supostas "periferias produtivas" menos dotadas.

Entre todos os envolvidos, o designer é um dos melhores atores dessa transformação e tradutor de cada uma das qualidades e da cultura de cada uma de nossas regiões. O Brasil possui um incrível e fantástico exército de obstinados que, mesmo muitas vezes isolados em seus redutos e limitados em suas ações, procuram, de forma competente, fazer com que a atividade profissional seja reconhecida e respeitada. É fundamental que não se analise a questão da "regionalidade" por um viés regionalista obtuso e coorporativo e se perca a possibilidade de vivenciar o rico e frenético surgimento de novos personagens nesse cenário em que o design consolida-se com suas contribuições e competências.

O design no Brasil firma-se, após mais de quarenta anos de seu estabelecimento oficial, como consequência e espelho de sua própria heterogeneidade local, desta vez, segundo Moraes (idem), vista como positiva, porque capta com mais precisão o pluralismo étnico e estético do Brasil. Essas características curiosamente apontam para a convivência de valores e sentidos múltiplos, fluidos e 
dinâmicos. O design no Brasil deve seguir adiante, enfrentando seus desafios de afirmação, de identidade e de reconhecimento internacional, sem carregar consigo nenhuma espécie de complexo de inferioridade por histórias e experiências não vividas. Mas ainda é preciso aumentar a percepção de que o design possa ser efetivamente estratégico para a economia do país. E esta é uma segunda questão. Uma das razões para não existir esse reconhecimento é justamente a falta de avaliação dos impactos desses programas na economia nacional. Segundo Heskett (2008), "sustentar as competências nacionais é muitas vezes visto como um apoio contra a invasão da globalização". 


\section{8 \\ CONCLUSÃo}

A indústria inovadora precisa de um profissional que seja capaz de inovar. Em outras palavras, precisa da Universidade que consiga formar esse profissional. Este é o principal produto que a Universidade pode oferecer à indústria.

(Grynszpan, 1999, p.28)

Apresento aqui algumas conclusões. A ideia é que, concluído, este trabalho possa fornecer, ainda que em caráter preliminar, um panorama do design finlandês e seu paralelo ou não com a produção brasileira como forma de subsidiar análises futuras, principalmente sobre qual o papel da universidade brasileira nesse universo.

Atualmente, a grande maioria dos países empenha-se no fomento do uso do design. As estratégias adotadas variam de país para país. Alguns optam por programas isolados, outros desenvolvem políticas para o design em planos mais elaborados. Em muitos países a promoção do design é parte integrante das estratégias de exportação, promovendo a imagem do país internacionalmente e melhorando a competitividade dos produtos. Mas, via de regra, essas políticas de design de diferentes países visam criar um ambiente de design, definir uma identidade nacional, gerar e atrair 
novas ideias e desenvolver um sistema de inovação competitivo. As estratégias utilizadas para implementar as políticas de design incluem programas de promoção, programas de suporte, criação de centros e museus de design, alocação de incentivos físicos e, ainda, crédito ou financiamento para a incorporação de design em projetos. Essas estratégias podem ser classificadas em três categorias, de acordo com sua função e seu público: as estratégias de suporte, as estratégias de promoção e as estratégias de educação.

O suporte consiste em suprir as deficiências das empresas e ocorre, normalmente, por meio de assessoria direta com financiamento dos governos traduzindo-se em programas que podem ser de curta duração, de assessoria contínua ou de treinamento, nos quais existe uma interação entre designer, o gestor do programa e a empresa. Os programas de assessoria contínua exigem que haja continuidade e estabilidade do suporte governamental, o que muitas vezes é difícil de viabilizar. Os programas de curta duração ocorrem de forma pontual e normalmente culminam com a exposição dos produtos desenvolvidos. Os programas de treinamento incluem seminários, workshops ou cursos, que são aplicados quando necessário ou quando possível.

A promoção do design é parte integrante de um esforço na busca de seu desenvolvimento e visa promover seu uso junto às empresas locais, informando a indústria sobre suas capacidades. Visa, ainda, promover o design nacional ou local no exterior e divulgar as vantagens do design junto ao público, atualizando também os próprios designers, além de contribuir para reforçar a imagem da região usando o design como identidade. Fazem parte deste formato as exposições, as feiras, os prêmios e concursos, as campanhas de promoção de marca nacional, seminários e palestras.

As políticas públicas de educação em design podem ser feitas por meio do incentivo às ações de aproximação entre escola e indústria, sugestão de novos assuntos para o currículo, programas de integração dos novos profissionais à indústria e incentivo a cursos de pós-graduação e à integração por meio da inserção de disciplinas de design em outros cursos. 
Inicialmente, pareceu-me que o design finlandês era resultado de uma somatória de aspectos (geográficos, históricos, culturais, sociais, econômicos) que resultaram na compreensão do real significado do design para a vida cotidiana. Ou seja, a questão moderna - entendida aqui como o desenho dos objetos sempre traduzindo as condicionantes anteriormente citadas - colocada na e por meio da prática e exemplificada em elementos os mais banais, e não de uma forma imposta, em que o designer detém o conhecimento do que é mais adequado para o usuário.

A pergunta é: isso é acaso, sorte, temperamento, VISÃO? Não existe aquele "mau projeto" com um "design ruim", nitidamente apenas com apelo comercial? Por outro lado, será que isto também não tem a ver com o design europeu, completamente diferente do design norte-americano, com o qual nós brasileiros estamos mais acostumados?

É fato que em termos de empresas/indústria o Brasil privilegia o modelo norte-americano, mas na universidade ainda se adota a postura do design moderno europeu ${ }^{1}$ e é bastante pontual a parceria empresa/universidade. Por outro lado, fosse qual fosse o "modelo" - sem entrar na discussão da validade das propostas modernas europeias e tampouco na questão da adoção de modelos prontos de outras realidades -, a questão foi a não identificação da necessidade nacional. Esse deveria ter sido um dos papéis da universidade, pois é lógico e evidente que a ótica/visão do mercado é outra (lucro).

Tal suposição revelou-se como não correspondendo à visão de "País das Maravilhas" em termos de design. Isto é, também lá é conflituosa essa relação design/público, e com posturas mais ortodoxas do que no Brasil. Por exemplo, o design finlandês é centrado

1 Apenas o ensino do design brasileiro nasce nos moldes do moderno europeu, onde o design surgiu da necessidade de se entender o novo ferramental, os novos meios de produção - a indústria - e a consequente necessidade de criação de uma nova linguagem decorrente desse mesmo contexto. Já a modernidade brasileira toma forma com as políticas de desenvolvimento do governo JK, e talvez já seja esta a origem do descompasso entre mercado e universidade. 
nele mesmo, ou seja, preocupação objetual e não contextual. Pensase na cadeira, e não para quem será a cadeira.

Mas se a Finlândia é considerada a "Meca do Design", não deve ser sem motivos. Assim, novamente, qual foi/é o caminho? E, se confirmada a premissa dos fatores socioculturais e históricos, como torná-la referência mundial não só para o Brasil? Por outro lado, apesar da cópia que de fato existe, essa mesma cópia leva aos poucos a uma cultura visual "moderna". Alguns pontos podem ser ressaltados, resultantes das visitas, entrevistas e leituras realizadas e que servirão de subsídios para futuras pesquisas.

A relação conflituosa design/empresa pode ser identificada por meio de alguns elementos. Os industriais - especificamente na área de mobiliário doméstico ${ }^{2}$-, donos de pequenas empresas familiares, estão acomodados em uma situação econômica confortável, sem os riscos inerentes de novos investimentos e sem perderem o poder de decisão nem a qualidade de vida e independência conquistadas. Paralelamente, não têm a compreensão do que é design realmente, apesar de entenderem que Good design MEANS good business, resultando em praticamente nenhum interesse por parte dos "grandes designers", os quais, por sua vez, acreditam não existir problema de mercado, pois sempre vai haver gente com recursos para consumir, existindo mercados para todos os gostos e preços, apesar de essa visão não ser a mais comum, o que gera uma falta de perspectiva de crescimento em termos econômicos e de marketing para essa visão "elitista" do design puro, pois o mercado interno não tem condições de absorvê-lo - o país é pequeno e a similaridade tecnológica, de materiais e formas é muito grande. De fato, foi recorrente a observação de que o problema do design finlandês é na relação com o mercado, e não na criação. Assim, o design finlandês tem

2 Durante o estágio de pós-doutorado, tive a oportunidade de visitar a região tida como principal polo moveleiro na Finlândia, assim como meu contato mais próximo na universidade foi com a área de design de mobiliário. Portanto, apenas e tão somente por esse motivo que neste trabalho a questão do mobiliário frequentemente aparece como exemplo principal. 
um problema de marketing, não de design, diferente da situação no final da Segunda Guerra Mundial ou na época da independência.

A nova geração consegue entender a necessidade de mudança de postura, mas questões como o interesse no usuário final, a inovação e design em companhias tradicionais, o design enquanto diferenciador em uma industrialização global, os desafios globais do design, a preocupação com produtos globais - não mais produtos locais - assim como com o conceito de um produto global, ainda não são comuns. Mesmo assim a relação com a indústria, mediada pelos profissionais saídos da universidade, é melhor que no Brasil.

Seria extremamente simplista, para não dizer estereotipado, afirmar que o design moderno finlandês dá certo porque ele é básico por natureza e, por outro lado, que o moderno no Brasil não funciona porque é/foi imposto. O interessante, seja qual for a situação, é o respeito à própria cultura. Por outro lado, é muito mais fácil valorizar algo nascido da sobrevivência ao frio, a guerras, etc. do que algo como o design brasileiro, nascido do carnaval, por exemplo. Entretanto, é imprescindível tomar cuidado com as alegorias, pois existem também na Finlândia e incomodam do mesmo modo.

Os programas de indução ao design na contemporaneidade também não são antigos, aliás, são mais recentes do que no Brasil. A relação é até mais conflituosa entre empresário e usuário e designer. A cópia também existe, só que nós tendemos a querer ser "mais realistas que o próprio rei" e sofremos de sérios problemas de autoestima. A complexidade social brasileira, as dimensões territoriais, a falta de homogeneidade, entre outros fatores, também fazem muita diferença. Por outro lado, não se pode esperar que designers de São Paulo, por exemplo, que têm condições de competir em termos tecnológicos, fiquem sempre desenvolvendo projetos alternativos ou só o contrário disso.

Especificamente, ainda no caso da análise do mobiliário doméstico, os valores que regem as escolhas são mais pessoais do que qualquer outra coisa, difíceis de se trabalhar. Consegue-se no máximo ir criando uma cultura visual por meio do mobiliário público e institucional e mantendo à disposição também esse tipo de reper- 
tório formal para o doméstico. Talvez uma saída seja desmistificar o discurso moderno no sentido purista/pejorativo, a modernidade real, entender o design como cultura de massa, entender qual é o papel decisório da universidade nesse complexo universo.

De qualquer forma, aqui, como em qualquer outro lugar no mundo, a práxis antecede a academia, e especificamente no caso do design, seu ensino formal é ainda bastante recente, o que nos faz debruçar sobre essas questões sem o distanciamento histórico às vezes tão necessário para um julgamento idôneo. E ainda, e como consequência, o ensino do design é analisado sob a ótica de outras áreas do conhecimento. Por outro lado, alguns teóricos reivindicam políticas diferenciadas para países em desenvolvimento devido à necessidade de se contemplar mais diretamente as causas sociais.

O sistema brasileiro é caracterizado por um grande e variado número de iniciativas, muitas delas com curta existência, sendo os recursos para manutenção dessas iniciativas provenientes principalmente do governo. Em contraste, algumas organizações privadas, sem fins lucrativos (por exemplo, o Sebrae, o Senai e a Federação das Indústrias), fornecem grande parte dos investimentos de design no país. Associações profissionais também são importantes instituições nesse sistema de promoção do design no Brasil.

Nas experiências em que se têm conhecimento da parceria empresa/universidade na área de design, ambas as partes mostram grande entusiasmo com a potencialidade do uso dos resultados na otimização de processos, no lançamento de novos produtos e na diminuição de custos, contribuindo para o aumento da competitividade das empresas. Incrementando cada vez mais o diálogo entre empresários, presidentes de sindicatos, pesquisadores e professores universitários, no sentido de identificar temas de pesquisa de interesse comum, o resultado final seria a formação de redes, o fortalecimento da interação universidade/empresa, a prática da negociação de projetos e o conhecimento das demandas das indústrias e do potencial de nossas universidades e centros de pesquisas. Além disto, seria importante um processo de mudança das políticas públicas incluindo maior participação do setor privado no financia- 
mento da pesquisa nos moldes já praticados nos países desenvolvidos. Esse tipo de iniciativa poderia ser um catalisador do processo de aproximação das empresas com as universidades e centros de pesquisa dentro do conceito de gestão do conhecimento. Isso permitiria aos alunos adquirir experiência acadêmica e maturidade na área da pesquisa aliada à experiência empresarial suficientemente longa e interessante para que consigam rapidamente um trabalho assim que se formassem. Desta forma, as pesquisas desenvolvidas poderiam conduzir a resultados aplicáveis nas empresas, as equipes dos laboratórios universitários aprenderiam a trabalhar afinados com a cultura industrial e dando continuidade às parcerias após o fim dos projetos, e por fim, mas não menos importante, os alunos estariam mais bem inseridos no mundo das empresas.

Entretanto, no Brasil ainda é muito reduzido o número de cooperações de empresas com universidades e centros tecnológicos, não se tendo ainda um ambiente que induza a empresa a investir em $\mathrm{P} \& \mathrm{D}$ com o objetivo de absorver novas tecnologias e pessoal capacitado.

$\mathrm{Na}$ verdade, essas colocações vêm ao encontro das necessidades identificadas por vários autores preocupados com a questão da cooperação entre universidades e empresas. O processo de inovação é um processo de aprendizagem interativo, que envolve intensas articulações entre diferentes agentes, requerendo novas políticas industriais, tecnológicas e de inovação e novos formatos organizacionais em rede. Nesse contexto, é fundamental o investimento na capacitação de recursos humanos, responsáveis pela geração do conhecimento. Chama-se a atenção para a capacitação como sendo um dos principais eixos estruturantes dos programas de cooperação entre universidades, centros de pesquisa e empresas, em que os resultados podem ser muito amplos, envolvendo a intensificação da inovação tecnológica na indústria, maior participação do setor privado no financiamento da pesquisa, a formação de redes de conhecimento tecnológico e mudanças das políticas públicas no setor de pós-graduação.

Sob esse enfoque, para que haja uma evolução no design brasileiro é necessário que este seja alimentado por um desenvolvimento 
cultural e social em todas as áreas, por meio de estímulos ao conhecimento e à criatividade nos vários níveis de educação - desde a educação primária até o treinamento profissional -, bem como nas diferentes comunidades, em diferentes campos e diferentes lugares. Essa relação retroalimenta-se, se for entendido que o próprio design pode ajudar na redefinição daquelas identidades culturais, perdidas em várias regiões, a partir dos processos de industrialização e de migração. Em outras palavras, se o design for visto como um instrumento para recuperar e revitalizar tradições e indústrias locais com o objetivo de transformá-las em vantagens competitivas.

Desta forma, políticas de design devem abranger ou articular-se com políticas que visem não somente ações de "fim de linha", tais como a divulgação, a promoção e as premiações ou com a inserção do design nas empresas - sem desmerecer a importância dessas ações -, mas que visem também a criação de condições nas quais mentes criativas possam ser "desenvolvidas e alimentadas".

Historicamente, os esforços de desenvolvimento científico e tecnológico no Brasil partiram de iniciativas governamentais, com participação bastante tímida do setor privado. Como resultado dessa política, esse desenvolvimento ficou desvinculado da indústria, a cargo das universidades e dos centros de pesquisa. Como consequência, o debate em torno da importância das atividades de pesquisa científica e tecnológica ficou, por muito tempo, restrito ao meio acadêmico, deixando-se de lado aquele que é o componente capaz de transformar ciência e técnica em riqueza, que é o setor empresarial.

Nas entrevistas realizadas, os principais problemas identificados na formação acadêmica e posterior atuação profissional são atribuídos às deficiências curriculares, pois, por definição, estamos falando sobre a formação de um profissional que deve estar em sintonia com a demanda de mercado na forma em que este se apresentar, ou seja, empresas privadas, órgãos públicos e até mesmo a academia. Mas, por outro lado, também conseguem identificar com clareza qual é o papel da universidade: a reflexão.

Pode-se concluir que os resultados desta pesquisa apontam para diversas questões que merecem um olhar mais cuidadoso. Primei- 
ramente, as iniciativas de design, mais amadurecidas, começam a alinhar-se com programas econômicos tais como certificação, qualidade em gestão, registros industriais, entre outros. Este é um ponto positivo que pode ser mais bem explorado com vistas à busca da competitividade da economia.

A questão da avaliação dos impactos é também uma preocupação atual em outros países, que há mais tempo vêm investindo em programas de design. Como o design sempre acontece junto a outras ações, fica difícil compreender e mensurar sua real importância dentro do processo.

Pode-se dizer também que instituições que promovem os programas de design não trabalham com indicadores precisos, existindo dificuldade em conhecer as bases metodológicas das ações, com poucas referências na literatura, o que dificulta a avaliação dessas ações. Os resultados finais fornecem dados imprecisos, que dificultam uma correta análise do programa para a proposição de eventuais correções para sua replicação.

Acredita-se que proporcionar uma formação em design é responsabilidade do governo, embora não haja evidências de nenhuma proposta para moldar essa formação por meio de novos métodos de ensino a fim de obter-se benefícios no futuro. Há, ainda, a falta de pesquisas na área de design, apesar de o governo patrocinar estudos em várias outras áreas de desempenho dos negócios, tais como tecnologia e competitividade.

Sugere-se que este tema seja mais amplamente debatido dentro dos meios acadêmicos, com o estímulo a estudos regionais e setoriais gerando referências e métodos mais bem estruturados, de modo a aprimorar a mensuração de impactos econômicos causados por programas de design. Essa análise, dadas as características da atividade do design, deve ser elaborada em cooperação interdisciplinar, para evitar uma abordagem somente sob a ótica do design.

Se é consenso a necessidade de entendimento do design pelos seus usuários, é oportuno ressaltar a necessidade de formação de um profissional com essa visão, para que os produtos sejam adequados às pessoas, e não o contrário, como é sabido que ainda ocor- 
re nessa área. Os cursos de design deveriam oferecer em sua grade curricular oportunidades que enfatizassem aos alunos a importância da compreensão das características culturais dos pretensos usuários. Neste sentido, uma metodologia de projeto em design considerando uma abordagem cognitiva poderia permitir ao aluno responder perguntas tais como: como os usuários percebem o mundo? Quais os significados que dão aos objetos de que necessitam? Como interpretam a imposição dos produtos que os rodeiam? De que forma se relacionam com os objetos projetados pelos designers? Em resumo, permitir ao futuro profissional conhecer a realidade cultural das pessoas para quem estão definindo aquele universo de objetos cotidianos.

Entretanto, há a necessidade do que poderia ser chamado de um "panorama favorável" para que a universidade pudesse ter agido dessa forma, e este só pode ser alcançado com políticas em design em que exista a priorização do design em si, e não visando apenas a competitividade das empresas em curto prazo, principalmente no mercado internacional. Do contrário, ainda enfrentaremos as constantes frustrações da falta de unidade entre design, empresa e sociedade. 


\section{REFERÊNCIAS BIBLIOGRÁFICAS}

AAV, M.; STRITZER-LEVINE, N. Finnish modern design: utopian ideals and everyday realities 1930-1997. New York: Norri \& Wang, 1998. ABEDESIGN. Brazilian design profile. São Paulo: Blucher, 2008.

BEZERRA, C. O designer humilde. São Paulo: Edições Rosari, 2008. BONSIEPE, G. Do material ao digital. Florianópolis: Sebrae, 1997.

BORNANCINI, J. C.; PETZOLD, N. I. Criatividade em projeto brasileiro. In LEAL, J. J. Um olhar sobre o design brasileiro. São Paulo: Objeto Brasil; Instituto Uniemp, Imprensa Oficial do Estado, 2002. BRANDÃO, M.; MAGALHÃES, F. (Orgs.). Brasil faz design. São Paulo: Brasil Faz Design Ltda., 2002. Brasil faz design. São Paulo: Brasil Faz Design Ltda., 2004.

BRASIL. Programa Brasileiro do Design. Orientação estratégica - PBD 2007-2012. Diretrizes da Pitce, Governo Federal, 2003.

BÜRDEK, B. História, teoria e prática do design de produtos. São Paulo: Edgar Blücher, 2006.

CARDOSO, R. Uma introdução à história do design. São Paulo: Edgar Blücher, 2004.

COELHO, L. A. L. (Org). Conceitos-chave em design. Rio de Janeiro: Ed. PUC-Rio; Novas Ideias, 2008.

COUTO, R. M. de S.. Escritos sobre ensino de design no Brasil. Rio de Janeiro, Rio Books, 2008.

GAYNOR, E. Finland, living design. New York: Rizzoli International Publications, 1984. 
GRYNSZPAN, F. A visão empresarial da cooperação com a universidade. RAUSP, v.34, n 4, out./dez. 1999.

HESKETT, J. Design. São Paulo: Ática, 2008.

JULIER, G. From Visual Culture to Design Culture. Design Issues, v.22, n.1, winter 2006.

KORVENMAA, P. The work of architects: the finnish association of architects 1892-1992. Helsinki: The Finnish Building Center, 1992.

Tapio vaara. Barcelona: Centre d'Estudies de Disseny, 1997.

Rhetoric and action. Design policies in Finland at the beginning of the third millennia. Scandinavian Journal of Design History, Copenhagen, Rhodos International Science and Art Publisher, v.2, 2001.

LEON, E. Design brasileiro: quem fez, quem faz. Rio de Janeiro: Editora Senac, 2005.

LÖBACH, B. Design industrial: bases para a configuração dos produtos industriais. s. 1.: Edgar Blücher, 2001.

MANZINI, E.; VELOZZI, C. O desenvolvimento de produtos sustentáveis: os requisitos ambientais dos produtos individuais. São Paulo: Edusp, 2002.

MIASSAKI, D; POUGY, G; SAAVEDRA J. Panorama das ações de design no Brasil. Relatório para agência brasileira de desenvolvimento industrial. Brasil: MDIC, 2006.

MONT'ALVÃO, C.; DAMAZIO, V. (Orgs.). Design, ergonomia e emoção. Rio de Janeiro: Mauad Editora; Faperj, 2008.

MORAES, D. de. Limites do design. São Paulo: Studio Nobel, 1999. Análise do design brasileiro. São Paulo: Edgar Blücher, 2006.

NORMAN, D. A. O design do dia a dia. Rio de Janeiro: Rocco, 2006. Design emocional. Rio de Janeiro: Rocco, 2008.

ONO, M. Design e cultura: sintonia essencial. Curitiba: edição da autora, 2006.

PERIÄINEN, T. Soul in design: Finland as an example. Helsinki: Kirjayhtyma, 1990.

POUTASUO, T. (Ed.) Finnish industrial design. Helsinki: Finnish Society of Crafts and Design, 1987.

RAULIK, G. Panorama internacional das políticas de promoção e incentivo ao design. Brasil: MDIC, 2006.

RICHARDS, J. M. 800 years of finnish architecture. London: David \& Charles, 1978.

SEGERSTAD, U. H. Modern scandinavian furniture. Helsinki: Otava Publishing Co., 1963. 
SANTOS, M. C. L. Móvel moderno no Brasil. São Paulo: Nobel, 1995.

SPARKE, P. Design in context. London: Quarto Publishing, 1987.

An introduction to design and culture: 1900 to the present. 2.ed. New York: Taylor \& Francis Group, 2005.

SPARSHOTT, F. The future of aesthetics. Toronto: University of Toronto Press, 1998.

STENROS, A. (Ed.) Visions of modern finnish design. Keuruu: Otava Book Printing, 1999.

THACKARA, J. (Ed.) Design after Modernism. London: Thames and Hudson, 1988.

VASCONCELOS, M. C. R. L.; FERREIRA, M. A. T. A contribuição da cooperação universidade/empresa para o conhecimento tecnológico da indústria. Perspect. cienc. inf., Belo Horizonte, v.5, n.2, p.167-82, jul./ dez. 2000.

WALTER, J. A. Design history and the history of design. London: Pluto Press, 1989. 


\author{
SOBRE O LIVRO \\ Formato: $14 \times 21 \mathrm{~cm}$ \\ Mancha: 23,7 x 42,5 paicas \\ Tipologia: Horley Old Style 10,5/14 \\ 1a edição: 2010 \\ EQUIPE DE REALIZAÇÃO \\ Coordenação Geral \\ Marcos Keith Takahashi
}

